\title{
SUSTAINABLE FASHION DESIGN: TRANSFORMABLE GARMENTS FOR VERSATILITY AND LONGEVITY
}

\author{
By \\ Minjie Gong, \\ Bachelor of Design, Suzhou, 2012
}
A Major Research Paper presented to Ryerson University
In partial fulfillment of the
requirements for the degree of
Master of Arts
In the Program of
Fashion

Toronto, Ontario, Canada, 2014

(C) Minjie Gong 2014 


\section{Author's Declaration}

I hereby declare that I am the sole author of this major research paper. This is a true copy of the major research paper, including any required final revisions, as accepted by my examiners.

I authorize Ryerson University to lend this major research paper to other institutions or individuals for the purpose of scholarly research.

I further authorize Ryerson University to reproduce this research paper by photocopying or by other means, in total or in part, at the request of other institutions or individuals for the purpose of scholarly research.

I understand that my major research paper may be made electronically available to the public. 


\title{
Sustainable Fashion Design: Transformable Garments for Versatility and Longevity Minjie Gong, 2014 \\ Master of Arts, Faculty of Fashion, University of Ryerson
}

\begin{abstract}
Practical explorations of transformable garment design are the core of my research, which aims to create sustainable design from an innovative perspective. This transformable design project creates a garment constructed from smaller components which can each be separated and recombined. The garment can be transformed, therefore, to reflect a wide variety of styles by detaching or replacing its individual components. This new, ecological design method for a multi-purpose garment reduces fabric waste, extends garment life span and engages the consumer in sustainable practices.

Transformable garments have a unique advantage in that they can both attract consumers and contribute to sustainable fashion. While this transformable project demonstrates great potential for design which cannot be fully explored here, the study provides critical insight into designer and consumer interests and practices in fashion sustainability. Along with providing greater awareness of sustainability issues in the fashion industry, the designs in this project bring sustainable fashion ideals one step closer to the mainstream.
\end{abstract}

Keywords: sustainability, sustainable fashion, transformable fashion, mass customization, 


\section{Acknowledgements}

I would like to convey my great gratitude to my supervisor, Professor Osmud Rahman. Without his endless support, encouragement, guidance, patience and belief, I would not have completed my studies. I would also like to thank Professor Sue for all of her instruction and suggestions on how to improve the quality of this research.

I wish to thank the participants of the online survey and interview for their generous time and invaluable insight. Special thanks should be given to Professor Qiongzhou Li and Professor Hui Huang at Soochow University in China, for sharing their knowledge and experiences with me. I also wish to thank Mr. Ziyang Zhang at Ryerson University for his great help on the interactive website design and Ms. Lu Cai at South Central University for Nationalities in China for rallying the participants of the online survey.

I am eternally grateful to my parents who have continuously encouraged me throughout my entire life, sacrificing so much and always supporting my decisions. I also wish to express a thousand thanks to my uncle, Henry Li, and aunt, Linda Sun, who have always believed in and supported me, especially throughout my graduate studies.

Last but not least, I thank my friends and my fellow MA Fashion classmates, for all the help, friendship, and encouragement they have given me throughout my studies. 


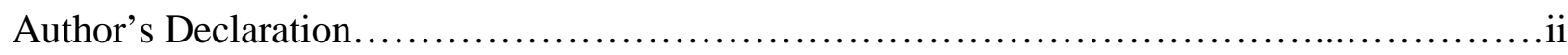

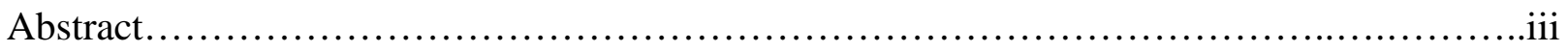

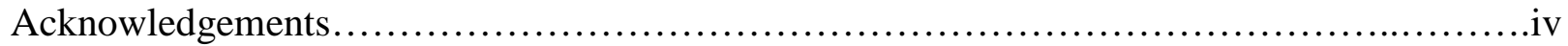

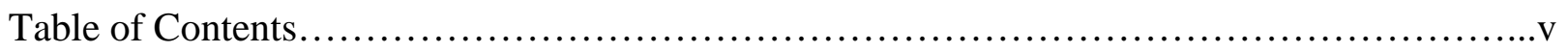

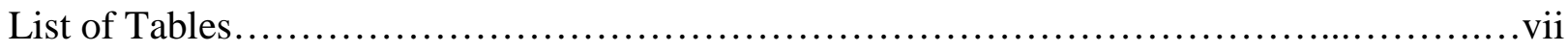

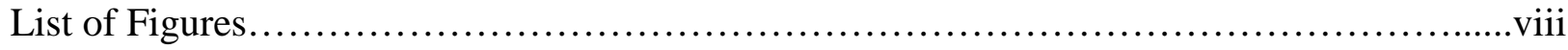

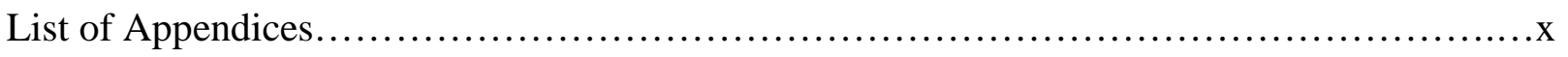

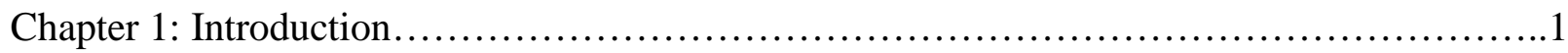

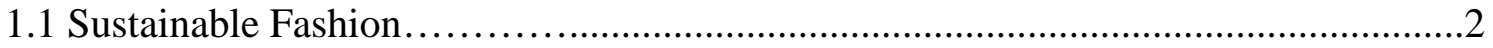

1.2 Mass production and Mass customization.................................................................2

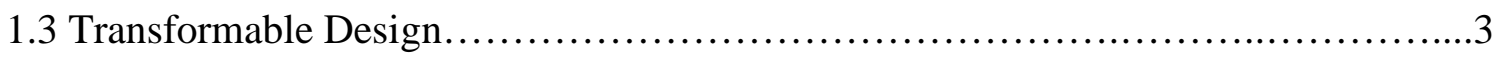

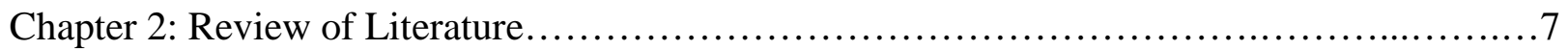

2.1 The Considerable Role of Design in Sustainable Fashion.............................7

2.2 The Importance of Versatility and Utility in Sustainable Fashion Design...............9

2.3 Consumer Engagement and Involvement in Sustainability..........................10

2.3.1 Customized fashion and sustainable clothing................................10

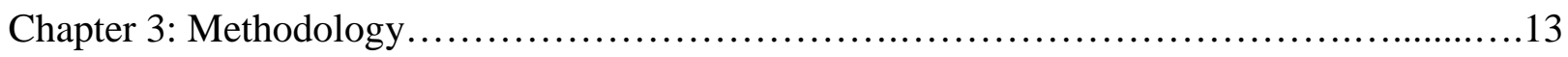

3.1 Experimental Research: Sustainable Fashion Designs...............................13

3.1.1 Summary of design experiments........................................13

3.2 Qualitative Research: Interviews and Survey of Design..........................14

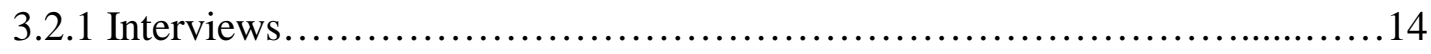

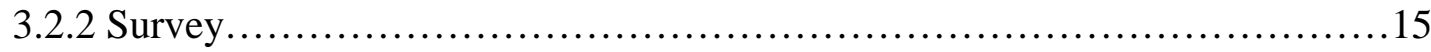

Chapter 4: Sustainable Fashion Product Design and Development..............................16

4.1 Design 1: One-piece Garment - Zero Fabric Waste Garment Design..................16

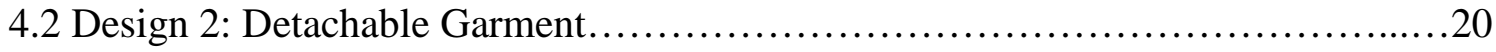

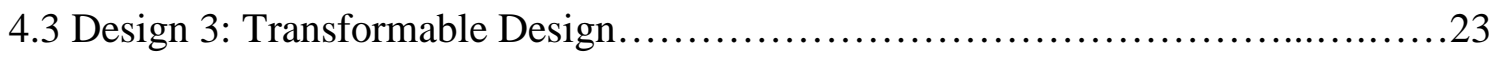

4.4 Stage 1: Researching and Purchasing Material.....................................24

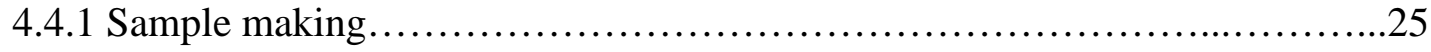

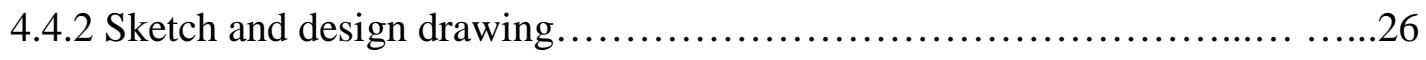




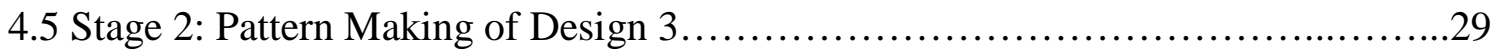

4.6 Stage 3: Design Change............................................... 30

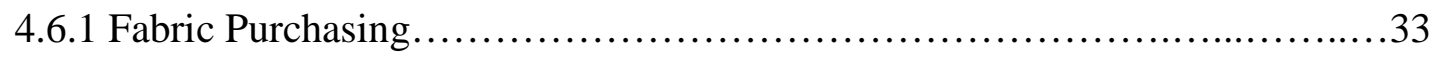

4.6.2 Draping, Design Alteration, Pattern Making and Modular Piece Making......33

Chapter 5: Research Findings...................................................42

5.1 Interviews......................................................... 42

5.1.1 Sustainable fashion.............................................43

5.1.2 Transformable design.............................................44

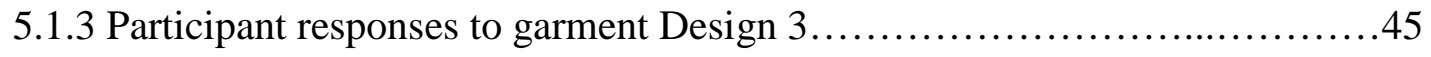

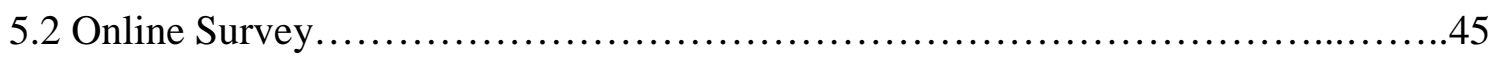

5.2 .1 Basic demographics.............................................. 45

5.2.2 Experimental design experiences...................................46

5.2 .3 Customized garments............................................ 50

5.2.4 Transformable garments......................................... 52

5.2 .5 Sustainable garments..............................................53

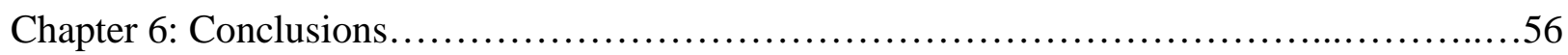

Appendix A: Approval from Ryerson Ethical Research Board ............................57

Appendix B: Interview Consent Form............................................58

Appendix C: Interview Questions...............................................63

Appendix C: Online Survey Questions.........................................64

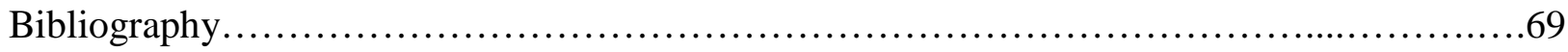




\section{List of Tables}

Table 1: Informant Profiles ..........................................................42

Table 2: Online Respondents’ Demographics......................................46

Table 3: Purchase frequency according to customized garments ...........................50

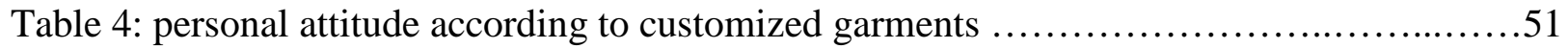

Table 5: Desirable options of customized features ......................................51

Table 6: Purchase experiences of transformable garments..............................52

Table 7: Use frequency according to purchased transformable garments....................52

Table 8: Change options of transformable garments.................................53

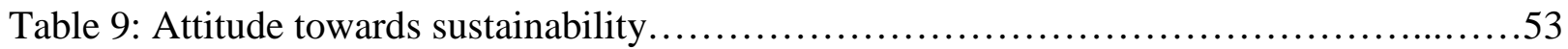

Table 10: Garment lifespan....................................................54

Table 11: Costs of purchased garments..........................................54

Table 12: Opinions of Chinese fashion market.........................................55

Table 13: Shopping intention toward customized design, sustainable design and transformable

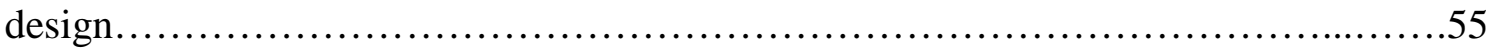




\section{List of Figures}

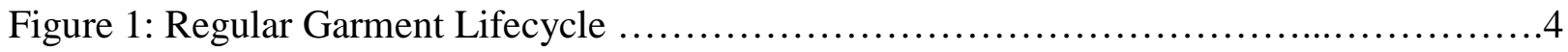

Figure 2: The Transformable Garment Lifecycle .........................................5

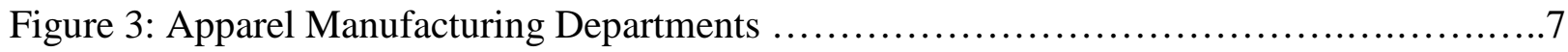

Figure 4.1: Fabric sample making for one-piece dress.................................17

Figure 4.2: Sketches for one-piece dress..........................................17

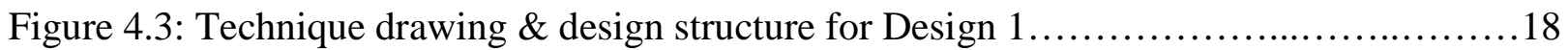

Figure 4.4: Design 1 - One-piece dress...........................................18

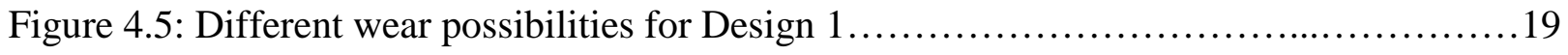

Figure 4.6: Different wear possibilities for Design 1...................................19

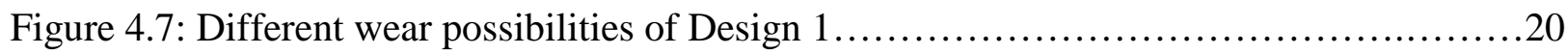

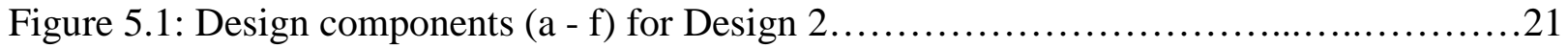

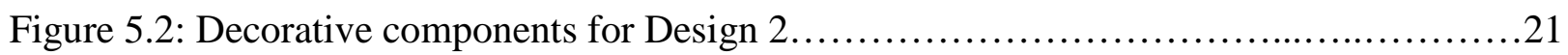

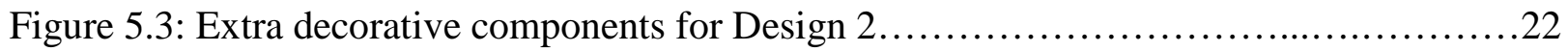

Figure 5.4: Design 2- detachable garment..........................................22

Figure 5.5: Transformable styles of Design 3- Detachable garment........................23

Figure 6: Design processes of Garment 3.........................................24

Figure 7.1: Sample making for zipper cross-connection technique $\ldots \ldots \ldots \ldots \ldots \ldots \ldots \ldots \ldots \ldots \ldots . .26$

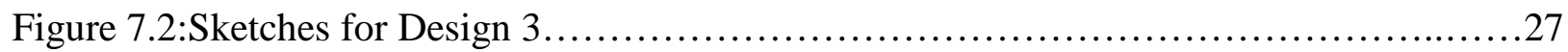

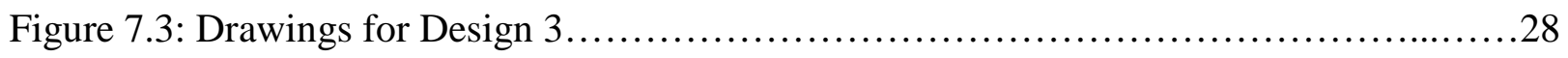

Figure 7.4: Garment 3. A for Design 3-transformable garment..........................29

Figure 7.5: Modular pieces for Garment 3.A...................................... 30

Figure 7.6: Inside layer of a modular piece for Garment 3.A..........................30 
Figure 7.7: Design 3-3.A; 3.B; 3.C............................................ 31

Figure 7.8: Drawings for Garment 3.B \& Garment 3.C....................................32

Figure 7.9: Main fabrics for Design 3- transformable garments...........................33

Figure 7.10: Garment modules for Garment 3.B.....................................34

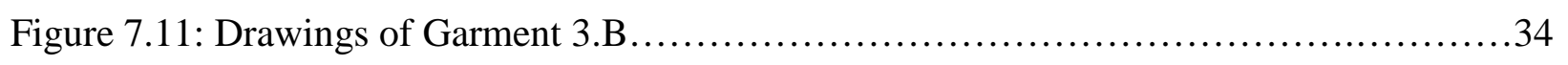

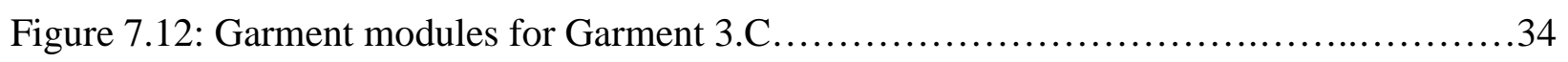

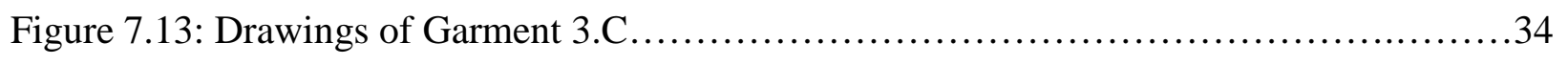

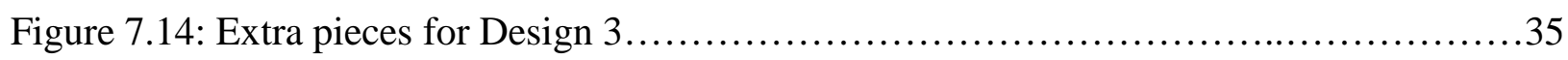

Figure 7.15: Design in progress of Garment 3.C........................................

Figure 7.16: Errors occurred with parts connection of Garment 3.A and Garment 3.B..........37

Figure 7.17: Garment 3.C-transformable garment.....................................38

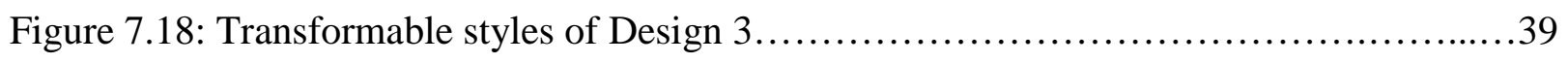

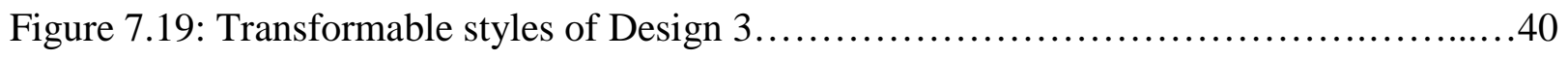

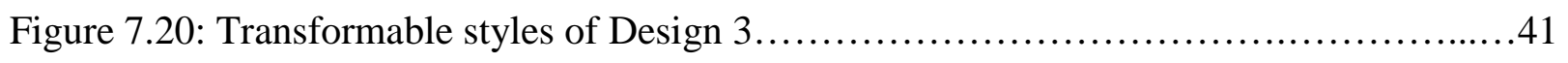

Figure 8: Co-design choices, part one.......................................... 47

Figure 9: Co-design choices part two........................................... 48

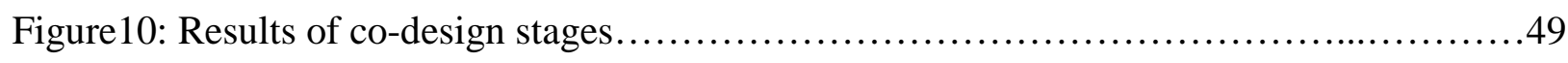

Figure 11: Satisfaction with Level of Design Experience................................49 


\section{List of Appendices}

Appendix A: Approval from Ryerson Ethical Research Board .............................57

Appendix B: Interview Consent Form............................................58

Appendix C: Interview Questions.................................................63

Appendix C: Online Survey Questions.............................................64 


\section{Chapter 1}

\section{Introduction}

It is evident that fashion design has become increasingly diversified and democratized. One can choose between a myriad of styles, such as hip-hop, hipster or punk, to reflect their personal preference and fashion trends.

Contemporary fashions are also now available to consumers at all price levels. The most appealing clothing type may be "fast fashion”, or, apparel that reflects rapidly changing styles at low price points(Tokatli, 2008).Consumers tend to purchase more clothing items when the prices are low or affordable and, as a result, more garments are sold than can actually be worn (Banim\& Guy, 2001;Woodward, 2007). Critics of “fast fashion” suggest that overconsumption has led to increasing fashion industry waste (Fletcher, 2008; Hawley, 2008). Nevertheless, the relationship between consumers and fashion companies is essentially an interactive one: designers offer a plethora of styles, season after season, and buyers (young consumers, in particular) consistently seek variety and novelty (Fralix, 2001). In the contemporary market, both parties bear responsibility for the production of sustainable fashion design. 


\subsection{Sustainable Fashion}

Ecological critics of the fashion industry today suggest that it is certainly out of kilter. As a part of growing trend to counteract the effects of "fast fashion”, blogs, books and business reports are increasingly promoting the practice of “sustainable fashion” (Gwilt \&Rissanen, 2011). The goal of sustainability is to “... meet[s] the needs of the person without compromising the ability of future generations to meet their own needs” (Brundtland Commission, 1987, Ch. 2,

paraI). Sustainable fashion, also known as eco-fashion, takes into consideration the total life cycle of fashion production. Sustainability is accounted for at every level: in design concept, the creation and use of materials, and in marketing, by promoting the ethical awareness of consumers. Eco-fashion can encourage greater environmental awareness and demonstrate the benefits of sustainable business practices for producers and consumers.

To promote ecological and sustainable fashion and reduce waste, designers are turning to new design concepts such as zero-fabric-waste designs (McQuillan, 2011; Rissanen, 2008), technology-enabled designs (Loker, 2008), and transformable designs (Fletcher, 2008). At the same time, sustainable fashion designers must continue to attract consumers’ interest and respond to their needs. Today, the greatest challenge for fashion producers may be in balancing sustainable fashion production with contemporary consumer demands for variety and affordability.

\subsection{Mass production and Mass customization}

In the contemporary fashion industry, apparel of different colors, features, styles, patterns, textures, functions, shapes and sizes provide customers with an overabundance of choice, and producers expect this great variety of mass produced garments to sell. Mass production (creating 
standardized goods at low cost in mass quantities) is currently the most universal apparel production model and is one that has been used by the industry for centuries. However, increasing consumer demands for individual and original designs have caused fragmentation among fashion producers. In 1987, Davis introduced the concept of “mass customization,” a production strategy that would cater to consumers' different needs and wants by providing them with customized products on a mass scale at a reasonable price. Mass customization was identified as a consumer driven business strategy that "uses information technology to efficiently produce customized goods and services with maximum differentiation through low-cost production” and characterized by individualized mass production (Anderson et al, 1997, I95A19/2). Compared with mass production, mass customization is a more effective and efficient way to satisfy consumers’ demands.

\subsection{Transformable Design}

The objective of this research, and from a designer's point of view, is to enhance sustainable outcomes by focusing on an innovative design process called transformable design. In this unique method, individual clothing components are connected together by fasteners such as zippers, hook and eyes, Velcro tape, and/or buttons. Each component can be unconnected and re-configured to create an entirely different garment style at the whim of the consumer. For example, if the basic shape is a long robe, the garment can be transformed into a long dress by removing the sleeves, or it can be transformed into a short skirt, a vest, and other styles by attaching/detaching different parts of the garment. Pockets and decorations can also be added to, (or removed from) the garment and different fabrics, patterns and/or colors can be used to replace individual, original pieces. The sustainable benefits of the transformable design concept 
are evident in the fact that an original garment can be transformed into a wide array of styles to serve different purposes as well as to prolong the life of the product.

The transformable garment can have a long lifetime, as consumers need only dispose of or replace worn-out parts. As shown in Figure 1, the traditional garment lifecycle process is made up of five stages: The first is comprised of raw materials (fabrics, threads, buttons, zippers, etc.); the second stage involves the industrial production of garments from these raw materials; the third reflects the transportation of garments from producers to consumers by different marketing channels; the fourth stage demonstrates consumer use, and the fifth stage, disposal.

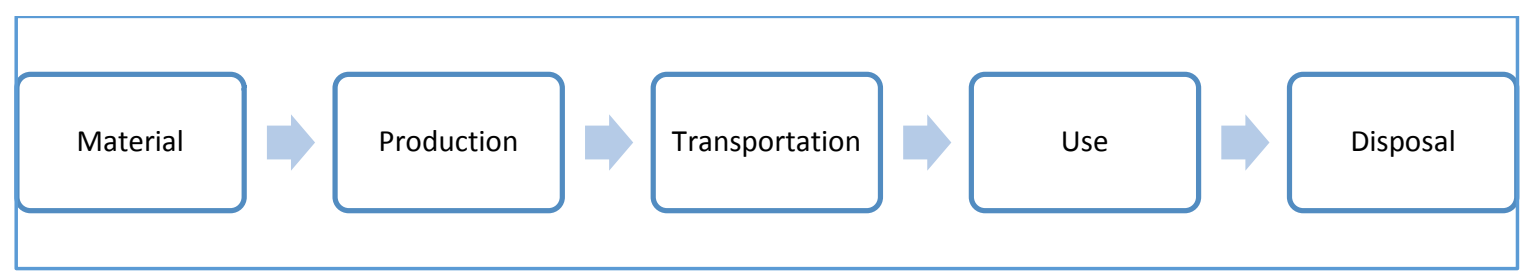

Figure 4. Regular Garment Lifecycle (Allwood, Laursen, de Rodriguez \& Bocken, 2006).

In contrast, the transformable garment lifecycle shows a clear difference in its last two stages. As demonstrated by Figure 2, both traditional and transformable garments share the same first three stages of raw materials, industrial production and transportation. However, the fourth stage (consumer use) is markedly different than the traditional model, as the transformable garment design reflects a re-circulation of use (as modified pieces replace worn-out parts) and a longer garment lifestyle. As any part of the garment can be replaced by a new piece, the amount of disposable materials makes a tremendous impact on the fifth stage, as the discarding of parts as opposed to the whole of the fabric results in a reduction to fashion industry waste. 


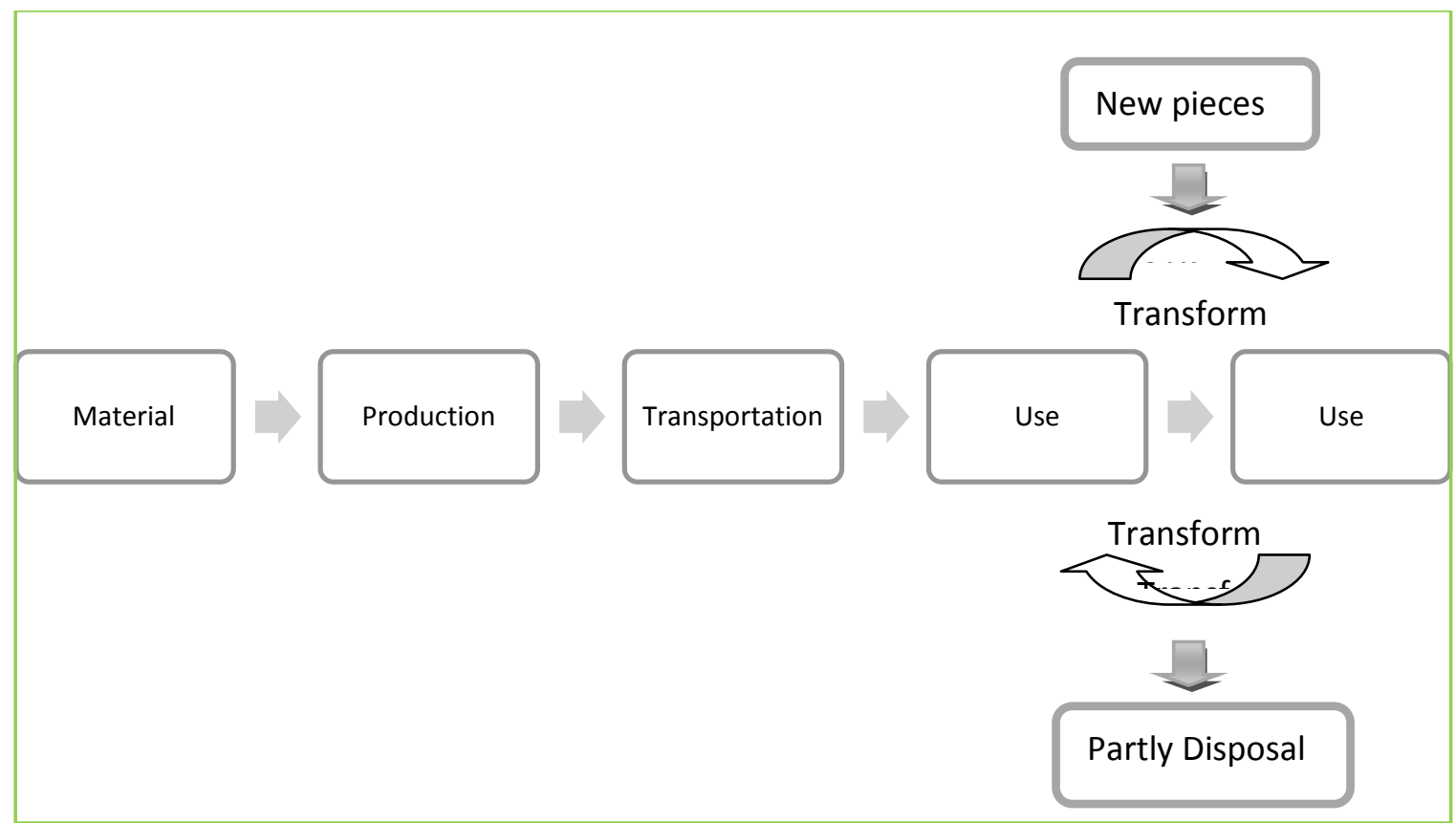

Figure 5. The Transformable Garment Lifecycle (modified from Figure 1)

To best promote transformable design, mass customization is the most appropriate marketing strategy. Because each component of the garment can be produced in different fabrics (such as leather, cotton, linen, jersey, etc.) and in different color and patterns, the item can be sold in individual pieces instead of as a whole package. This allows consumers to buy a basic garment shape, choose and separately purchase different component pieces they like, and design the finished piece as suits their needs at the moment. Furthermore, if some parts of the garment are ripped or destroyed by wear, new pieces of the same parts can be replaced and the consumer need not throw away the entire garment. The ability to both co-design and prolong the life of favoured clothing items are some unique advantages of transformable design that may attract consumers.

The overall benefits therefore, of the transformable garment are: increase the possibility and variety of consumer use, diversity in style, reduction of waste, longevity of garment life, and potential enhancement of greater consumer satisfaction over time. The transformable garment 
can also, significantly, promote greater consumer involvement with sustainability practices. Instead of educating consumers about sustainability through the media or publications, the transformable garment can act as an active agent for ecological change by engaging the consumer through direct participation in fashion production

Practical explorations of transformable garment design are at the core of my research, which aims to promote sustainable design through innovative perspectives. In order to reduce overconsumption and offer renewable solutions, I have created several sustainable fashion styles, and propose a mass customized design method to satisfy consumers’ constantly changing demands. Through this project, I mean to demonstrate how transformable fashion design can significantly reduce fabric waste, extend garment life and more directly engage and involve consumers in sustainability practices. 


\section{Chapter 2}

\section{Literature Review}

The literature review is divided by three parts. The first part covers general knowledge about fashion design processes and how apparel designers can increase sustainability in garment design. The second part reviews existing transformable garments and the importance of versatility and utility in sustainable fashion design. The third part explores the role of consumer in sustainable fashion and examines mass customization strategy from aspects of both consumer's interests and sustainable fashion.

\subsection{The Considerable Role of Design in Sustainable Fashion}

Sustainability can be achieved in the fashion industry through many means, including garment design, fashion marketing, and the consideration of consumer behaviour. The most efficient way to promote sustainable fashion, however, is through fashion design. In the fashion industry, manufacturing departments often follow a linear production model (see Figure 3). Each phase of design and product development, materials acquisition, production, sales and distribution all operate separately and are only initialized once the previous phase is complete. The first phase, design and product development is the most influential stage because design choices affect the material waste created at each phase of the production process, as well as product consumption, disposal, and recycling (Loker, 2008).

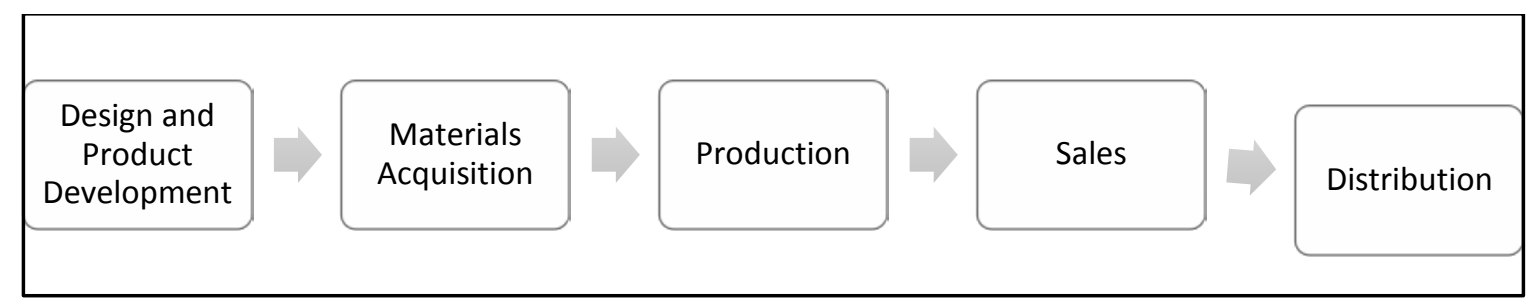

Figure 6. Apparel Manufacturing Departments (Loker, 2008) 
To encourage designer involvement in sustainable fashion, Ann Thorpe (2005) argues, “designers could incorporate time and dimension into their design philosophy...designing resilient clothing to last beyond their life time to generations in the future” (as cited in Loker, 2008, p. 99). There are various design methods that can help to increase sustainability in the fashion system - effective designs should offer garments with longevity, diversity and versatility (Dombek-Keith \& Loker, 2011).

One of the main challenges of sustainable fashion design lies in its goal to reduce fabric waste. Even in the clothing production process, there is up to 10 to 20 percent of fabric wastage (Rissanen, 2008). To reduce fabric waste, a strategy known as Zero-Fabric-Waste design employs a sustainable method based on design re-patterning, which is an experimental practice undertaken during the pattern-making process in garment production (2008). In his dissertation “Creating Fashion without the Creation of Fabric Waste”, Timo Rissanen, a zero-waste pioneer, discussed pattern-making wastage, fashion creation methods, and less wastage fashion designs. He presented a number of zero-waste related designs, from the "tuta”, which was designed by an Italian futurist in 1919 to the zero-fabric-waste dress collection designed by Mark Liu in 2007. Rissanen’s research focused on jigsaw puzzle garment designs in which the fabric pieces interlock, similar to jigsaw pieces. This design allows dressmakers to cut the fabric from a twodimensional unified whole to produce a three-dimensional garment without waste. Following Rissanen’s work, an increasing number of researchers have made contributions to Zero-FabricWaste sustainable fashion design (Black, 2008; Bye, 2010; Farrer, 201; Fletcher, 2008; Lewis, 2008; Loker, 2008; Luke, 2008; McQuillan, 2011). Apart from the concept of Zero-Fabric-Waste, extending the lifespan of a garment is another approach. 


\subsection{The Importance of Versatility and Utility in Sustainable Fashion Design}

One of the key benefits of sustainable fashion design is garment longevity. There are many ways to extend a garments’ lifespan, including making high quality garments, using highquality dyes for longer-lasting color, and re-designing existing garments. Vartan (2008) claims that modifying, refurbishing and repairing existing garments is a more efficient way to achieve sustainable fashion than constantly purchasing new styles. Transformable garments reflect this efficiency as they can be modified and repaired by detaching and replacing different pieces, thereby extending its lifespan and reducing overall consumer consumption.

A garment that has versatility and hybridity is another effective solution to enhance sustainability. If an article of clothing can change colors, or be modified by the user in pattern and style, it has a better chance of being worn more often. As a result, a consumer's need for buying and consuming new and different garments will more likely be reduced (Black, 2008). In addition, traditionally designed garments are usually purchased for specific occasions and /or seasons (e.g. winter jacket, shorts, vest...), whereas transformable garments can be used in multiple contexts. Though the idea of transformable, sustainable fashion may seem new, numerous designs for multi-functional garments have appeared in the history of fashion, including the 'A piece of cloth’ (A-POC) collection by Issey Miyake (Miyake, Fujiwara, Kries \& Vitra Design Museum, 2001) the ‘Firefly Dress’ designed by Orth, Post and Cooper (Huang, 2011) and the color-changing dress collection made by researchers in Yonsei University (Lee, Cho, Lee, \& Cho, 2010).In order to design a garment with longer lifespan to serve multiple purposes, it is important to understand how consumers interact and engage with the product. 


\subsection{Consumer Engagement and Involvement in Sustainability}

Fashion design can indirectly affect consumer behaviour to a point where buyers play an important role in the system of sustainable fashion. In many cases, the responsibility of sustainable practice is attributed to consumers rather than designers (Fletcher, 2008) because sustainable designers are more often held accountable for the production process rather than consumer use (Dombek-Keith \& Loker, 2011). In order to further encourage consumer involvement in sustainable fashion practices, detachable garment design with its active consumer participation enables an extended use with fewer garments (Gwilt \& Rissanen, 2011).

2.3.1 Customized fashion and sustainable clothing.Customized clothing has long been an option for consumers looking for original, tailored fashions. Before the industrial revolution, garments were mostly custom made to meet individual needs. In the contemporary fashion industry, however, handmade garments and tailored designs exist in niche markets aimed at the upper class. The majority of fashion consumers today are attracted to, and can only afford, clothing that is mass produced. Consumers and producers both benefit from mass production, as it reduces the cost of making goods and generates output in large quantities. Mass production can, therefore, provide goods for consumers at minimized prices and generate maximized profits for the producer.

Mass customization is an emerging, alternative production and business strategy that combines advantages from both customization and mass production. This approach can also better support sustainable fashion practices in the industry. Pine (1993) identifies mass customization as: 
a new way of viewing business competition, one that makes the identification and fulfillment of the wants and needs of individual customer paramount without sacrificing efficiency, effectiveness, and low cost. (p.xiii)

In mass customization, it is not only that designers offer consumers individually customized goods and services (Pine, 1993), but that they engage in a memorable consumption experience (Fiore, Lee, Kunz \& Campbell, 2001). Mass customization fulfills consumers’ desire for experience (Fiore, Lee \& Kunz, 2004). The advantages of mass customization can be seen in the success of various companies, such as Ikea, Lego and Levi’s. Levi’s ‘Personal Pair’ collection, for example, is customized to provide buyers jeans with personalised measurements of waist, hips and rise (Lott, 2001). Customer satisfaction and engagement with the brand is demonstrated by this statistic: “the repurchase rate for Levi’s Personal Pair custom fit jeans was 38 percent as opposed to 12 percent for its traditional jeans” (Berman, 2002, p.54)

Fashion designers can choose from many different types of mass customization, such as adjustable customization, dimensional customization and modular customization to suit their needs (Senanayake, 2004). Adjustable customization refers to the adjustment of different design features to customize products, such as one design for two uses. Dimensional customization refers to cloth made with standardized designs and customized dimension, for instance, the tailor shop. Modular customization refers to provide a wide variety of products and services by combing and adjusting the modules (Anderson \& Pine-II, 1997). To be specific, producer could repeatedly produce modular components where customization can be achieved by varying combinations (Pine, 1993). For example, Lego company. Modularity has been viewed as the most essential element of achieving mass customization (Duray, Ward, Milligan \& Berry, 2000; Feitzinger \& Lee, 1997; Pine, 1993; Sawhney, 1998). 
The appeal of mass customization has also been proven in the fashion industry. A 2001 article from The Critical Thinking Consortium, for example, reported that many consumers would prefer to purchase customized apparel and footwear even if they must pay more for these items (Fralix, 2001). More consumers today are willing to (and want to) design their own apparel by modifying various features, such as color, texture, print, dimension and style (Lee, Kunz, Fiore \& Campbell, 2002). Buyers do not only benefit from wearing original, personalized designs, but also gain a memorable consumption experience (Fiore et al., 2001). Several apparel companies have already incorporated modular design and production into their mass customized collections. Online sales are frequently used interactive platform for customers approach in mass customization. A growing number of apparel companies are now offering mass customization services on their websites, such as Customink, Zazzle, Brooks Brothers, Converse, Land's End and Nike. 


\section{Chapter 3}

\section{Methodology}

In this research project, I employed a mixed methods approach which included sustainable fashion design experiments and investigation, interviews and online surveys. The design experiments focused on sustainability and mass customization.

\subsection{Experimental Research: Sustainable Fashion Designs}

Sustainable fashion needs to be experienced and applied to everyday practice (Fletcher, 2011). In order to reach the goal with the strongest design solutions, various design methods and design samples were created and used. I created seven garment designs which comprised the entire sample grouping (these included six individual styles and one final collection of sustainable fashion designs). I then created a comparison chart to analyze the advantages and disadvantages of each design. All of these designs were created based on sustainable fashion design concepts, including one piece designs, and transformable/detachable designs.

\subsubsection{Summary of design experiments.}

- Design 1: a one piece design which a piece of rectangle fabric shaped by elastics without fabric waste.(See Figure 1)

- Design 2: a detachable design comprised of several individual components that are made with two layers of fabric. Instead of sewing each piece of fabric together in the production process, I attached interlocking hooks and eyes which can be connected and separated by the user. Each fabric piece, therefore, functions separately from the other and both are reversible. The user can change the garment's style in varying ways by detaching and re-attaching different parts to different areas.(See Figure 2) 
- Design 3: the final collection of transformable design, which is an extension of Design 2.The collection features a number of components which can be separated and changed. In order to keep all the pieces in place, these components are connected by zippers, rather than hook and eye fasteners. (See Figure 3.16)

\subsection{Qualitative Research: Interviews and Survey of Design 3}

In the second phase of the research, I conducted one-on-one interviews and online surveys in response to the Design 3 (transformable design collection), to obtain professional fashion insiders' advice and consumers' opinions about this innovative design method. I created a variety of interview and survey questions to investigate the sustainability, aesthetics, functionality, and commercial possibilities of the Design 3 garment collection.

3.2.1 Interviews.I conducted one-on-one interviews with seven fashion professionals (both adult men and women): two fashion designers, two fashion scholars, and three entrepreneurs. I recruited the participants through referrals and from Soochow University in Suzhou, China. I interviewed fashion professionals in four cities of China: Suzhou (two scholars), Shenzhen (two entrepreneurs and one designer), Nantong (one entrepreneur) and Nanjing (one designer). During the interviews computer-generated visual images were used as a vehicle to elicit informants' perceptions and opinions (Harper, 2002) of Design 3. Each interview was audio-recorded and later transcribed, and the length of interviews were ranged from 30 to 60 minutes. My main expectation in interviewing these particular participants was to gain information about the current production status of sustainable and transformable garment manufacturing in the Chinese market. Through the interviews, I also hoped to identify the advantages and disadvantages of the transformable garment design, and to consider the feasibility of manufacturing and launching the design in the Chinese market in the future. 
3.2.2 Survey.Consumers' opinions of transformable design were collected by conducting a public online survey, which included an experimental customization design section and 25 survey questions. The survey questions garnered consumers’ opinions about purchasing sustainable fashion, mass customized garments and transformable designs. Survey was designed and developed to seek responses from both male and female Chinese consumers, it took each respondent about 15 to 30 minutes to answer all the questions.

As an experiment in the custom design process, in the design section of the survey, I created and posted an interactive website online which featured modular components of the transformable design collection. Online participants were prompted to choose different components to customize their own designs. I then used the collected quantitative data to analyze consumers' interests and perceptions of Design3. The 25survey questions provided insight into Chinese consumers' perception of sustainable, transformable and customized garments, and provided information on consuming and shopping behavior, average price of clothing purchase, and demographics (e.g. gender, age, occupation and location).

I then used the qualitative from the interview and quantitative data from the survey to analyze the commercial possibilities, desirability and sustainable effectiveness of the transformable garment. 


\section{Chapter 4}

\section{Sustainable Fashion Product Design and Development}

\subsection{Design 1: One-piece Garment - Zero Fabric Waste Garment Design}

For my first design, I meant to explore potential sustainable design methods and began with a one-piece garment concept that focused on transformation, flexible garment shape and aesthetic value. My model was primarily inspired by both origami patterns ${ }^{1}$ and the 'New York by Gehry, ${ }^{2}$ building, a skyscraper featuring a rumpled and shifting surface. In order to recreate a texture similar to the stainless-steel skin of Gehry’s building, I chose white artificial leather for the garment, and also developed an elastic frame to create a corrugated origami feature.

During the garment design and production process, the first stage involved fabric sample making, as shown in Figure 4.1. This figure demonstrates how the elastic structure, combined with the weight and texture of the fabric, supported the corrugated architectural shape. In the second stage, I developed design sketches and technical drawing (see Figure 4.2 and Figure 4.3) outlined the work process for the one piece design (a rectangular piece of cloth without any cuts). I sewed several elastics into the fabric, and then gathering and ruching them at the top and bottom of the rectangular piece, and also added one elastic to each vertical edge of the cloth. Figures 1.4 to 1.6 illustrate the garment's versatility, and show a wide range of possibilities for wear and its suitability for different body types. This design demonstrated potential for using elastics in one piece garment.

\footnotetext{
${ }^{1}$ https://www.flickr.com/photos/jorge_ayala/2873275158/

${ }^{2}$ http://www.newyorkbygehry.com
} 


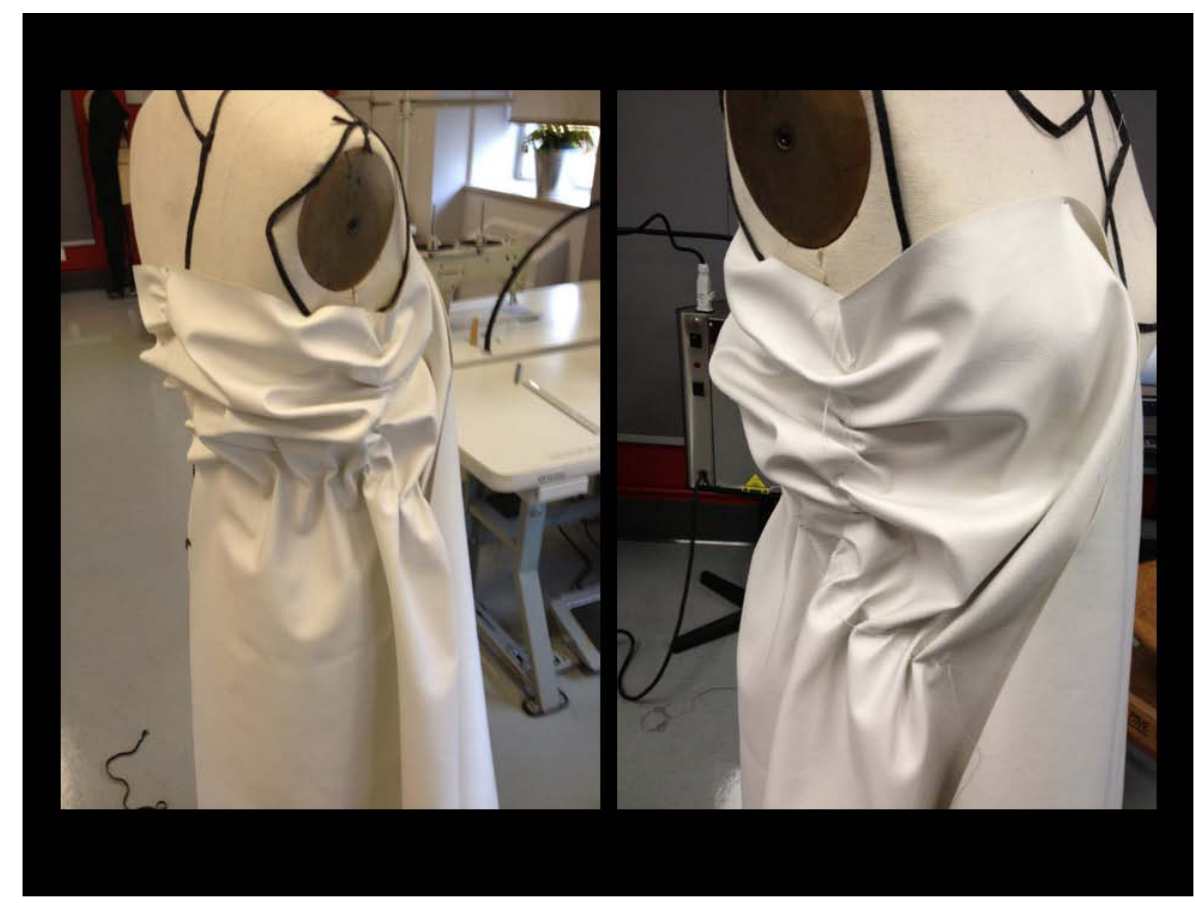

Figure 4.1. Fabric sample making for one-piece dress

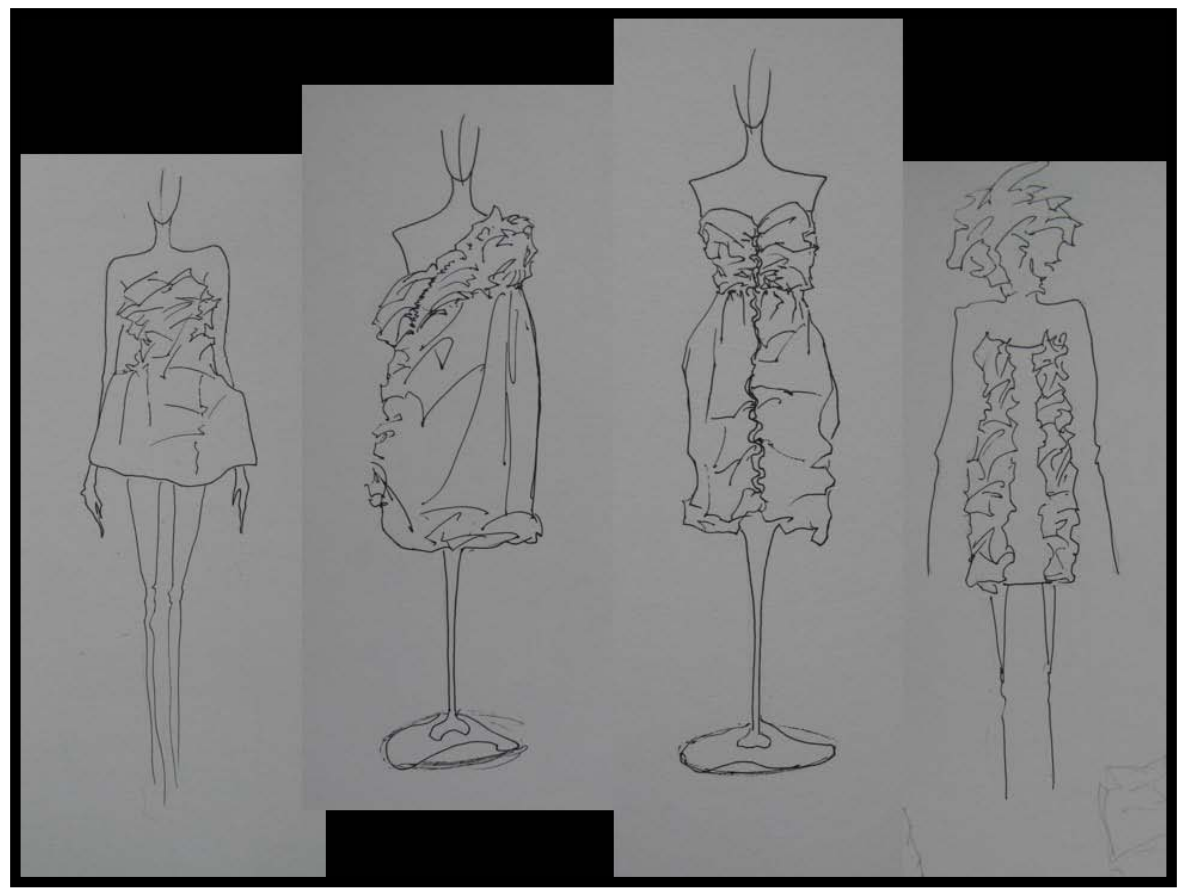

Figure 4.2. Sketches for one-piece dress 


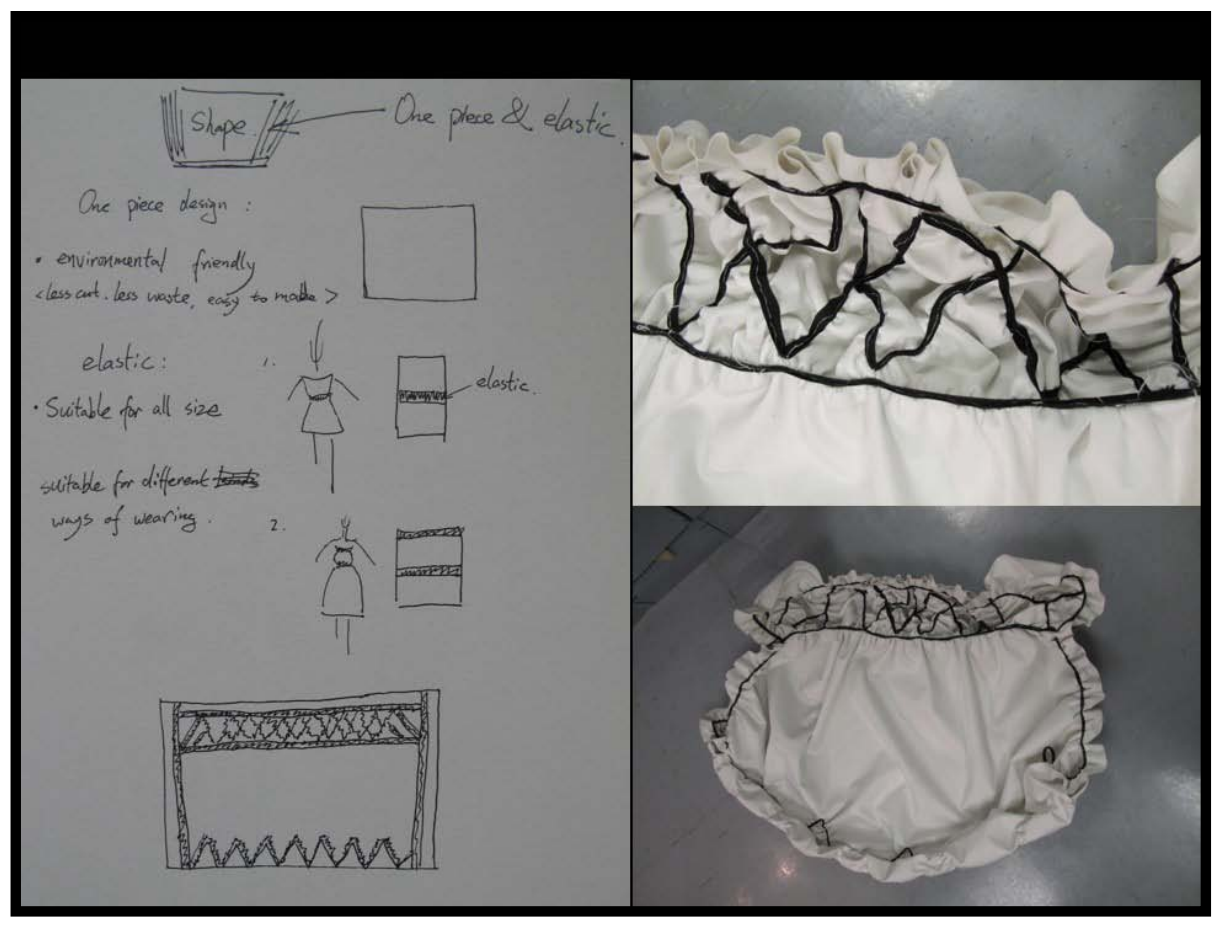

Figure 4.3. Technique drawing \& design structure for Design 1

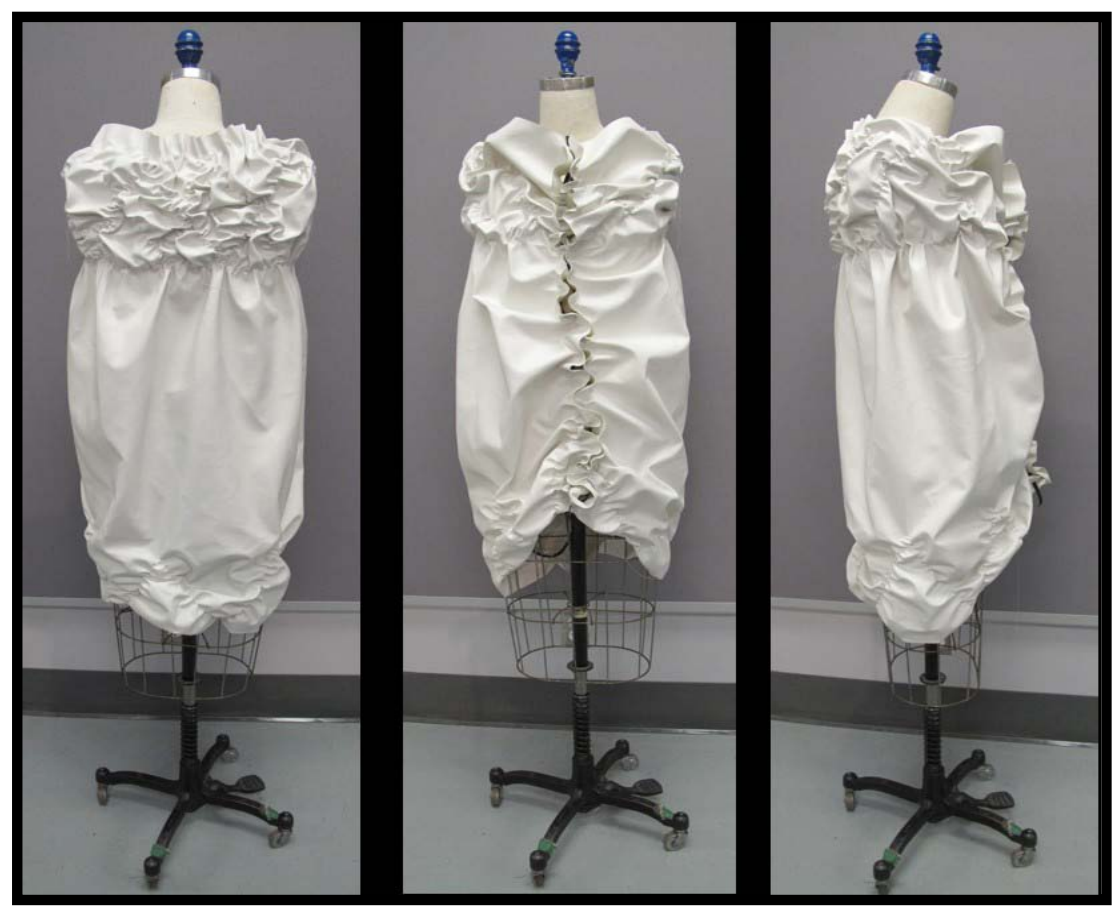

Figure 4.4. Design 1 - One-piece dress 


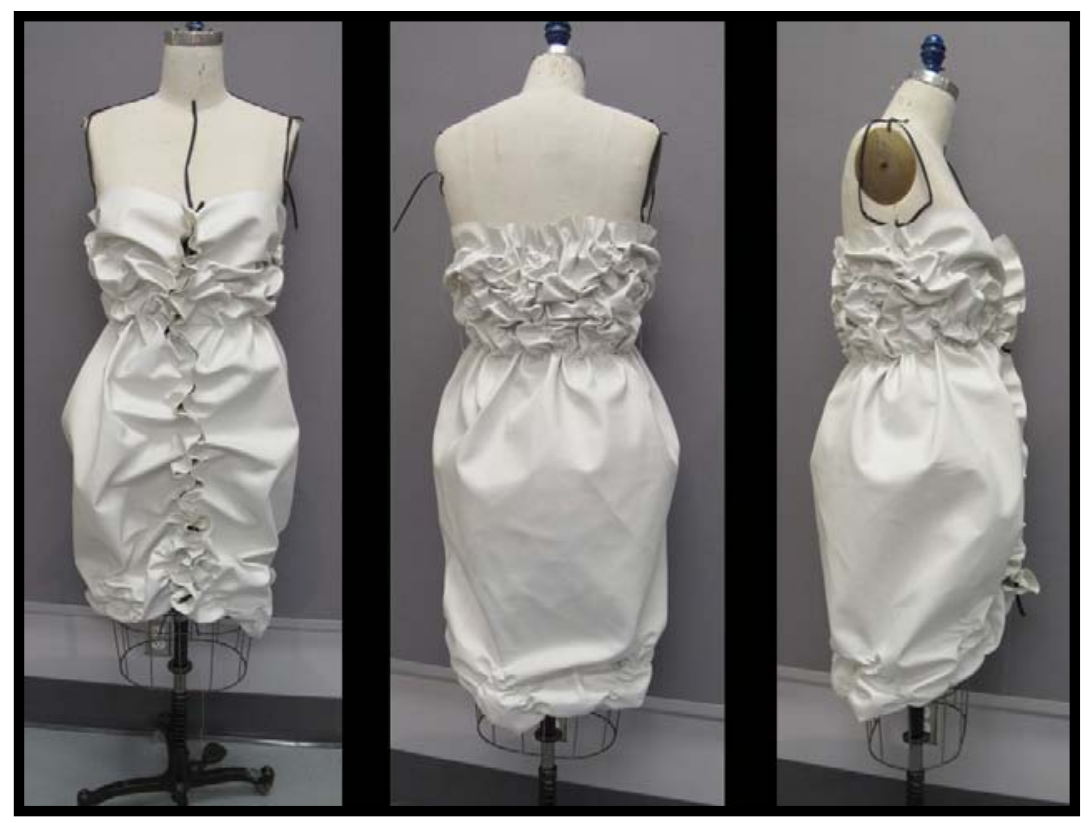

Figure 4.5. Different wear possibilities for Design 1

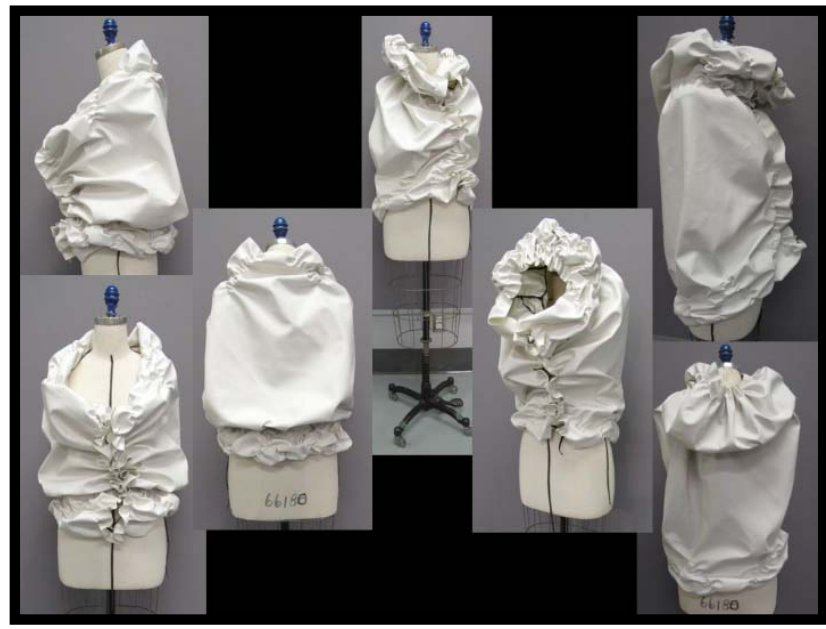

Figure 4.6. Different wear possibilities for Design 1 


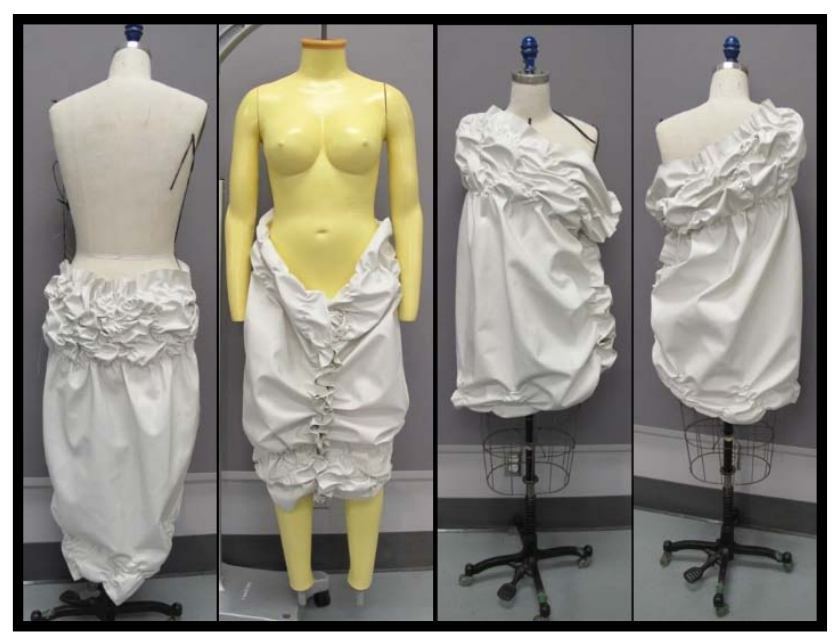

Figure 4.7. Different wear possibilities of Design 1

\subsection{Design 2: Detachable Garment}

My second detachable design was inspired by a simple, childhood object—-the Lego brick. The brick (the building block of the Lego construction kit) was introduced in 1958 and is the most important product of the Lego brand (Lego.com, 2014). Lego bricks are sold in packages with hundreds of pieces which can be connected and assembled in different ways to construct various objects; the interlocking feature offers the user unlimited building possibilities. Lego constructions can then be broken down into individual pieces and used to build anew. Lego's slogan promises that "It's just a matter of getting the imagination going - and letting a wealth of creative ideas emerge through play” (Lego.com, 2014).

To create the Infinite Dress, (Design 2), I adjusted the traditional garment making process of making a long dress. As Figures 5.1 and Figure 5.2 demonstrate, I constructed the garment from six main parts: front top (Figure 5.1.a), the shoulder-strap (Figure 5.1.b), front bottom (Figure 5.1.c), back top (Figure 5.1.d), back bottom (Figure 5.1.e), hem (Figure 5.1.f) and three decorative parts (Figure 5.2). 
Each part of the garment was designed to be separated and reassembled by garment accessories (82 hooks and eyes in total). All of these pieces have two sides, one black and the other white (Figure 5.2). Each part of the garment can adjusted individually, and interchanged with other fabrics of varying colors and patterns. I designed two extra decorative parts to interchange with this design (Figure 5.3). This sustainable long dress (Figure 5.4) can be transformed to reflect at least 80 different styles by detaching and interchanging individual parts (Figure 5.5).

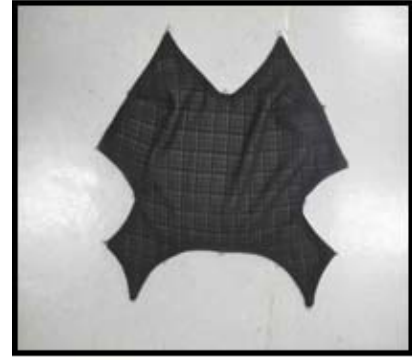

a

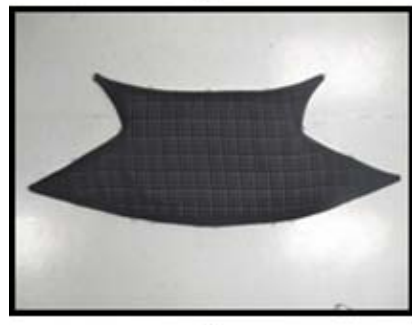

d

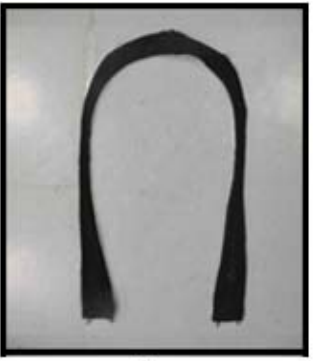

b

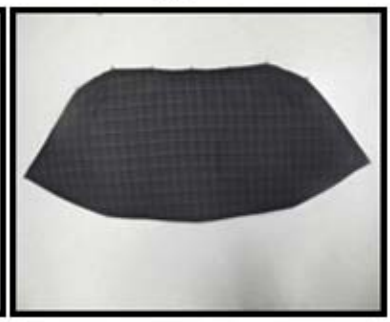

e

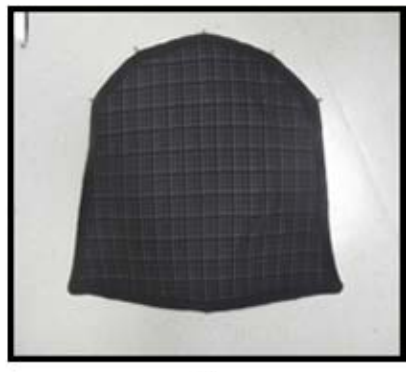

C

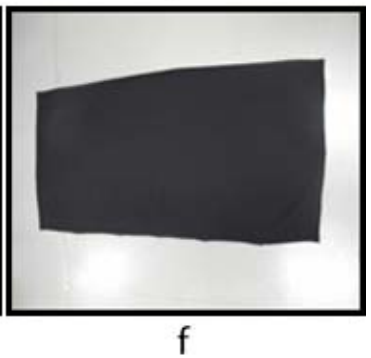

$f$

Figure 5.1. Design components $(a-f)$ for Design 2

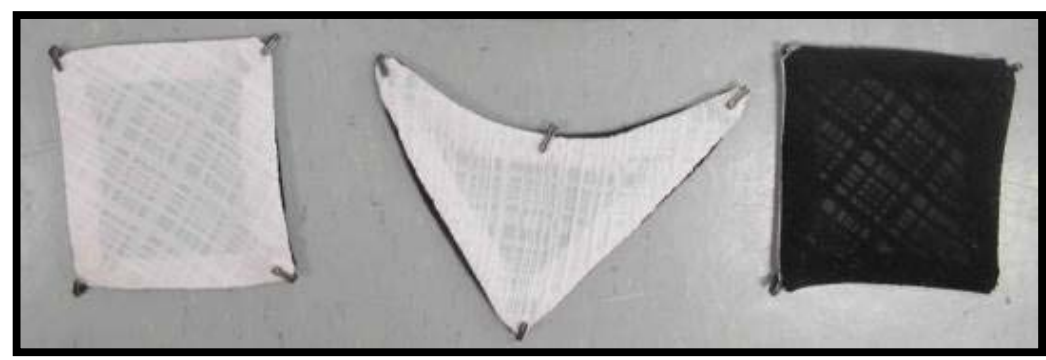

Figure 5.2. Decorative components for Design 2 


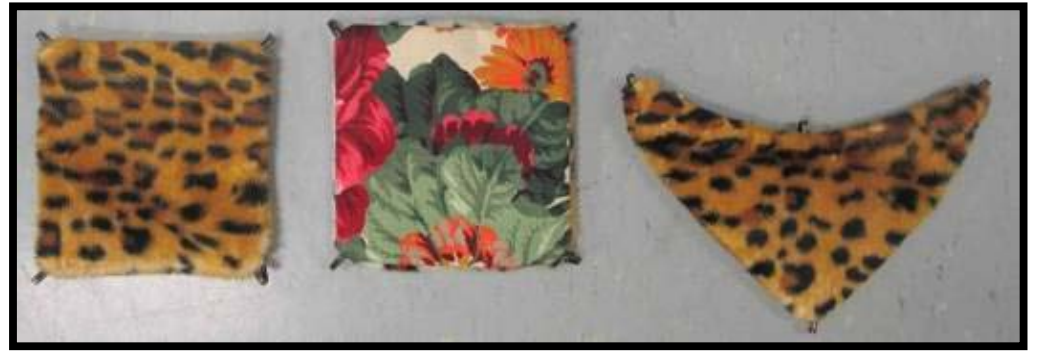

Figure 5.3. Extra decorative components for Design 2

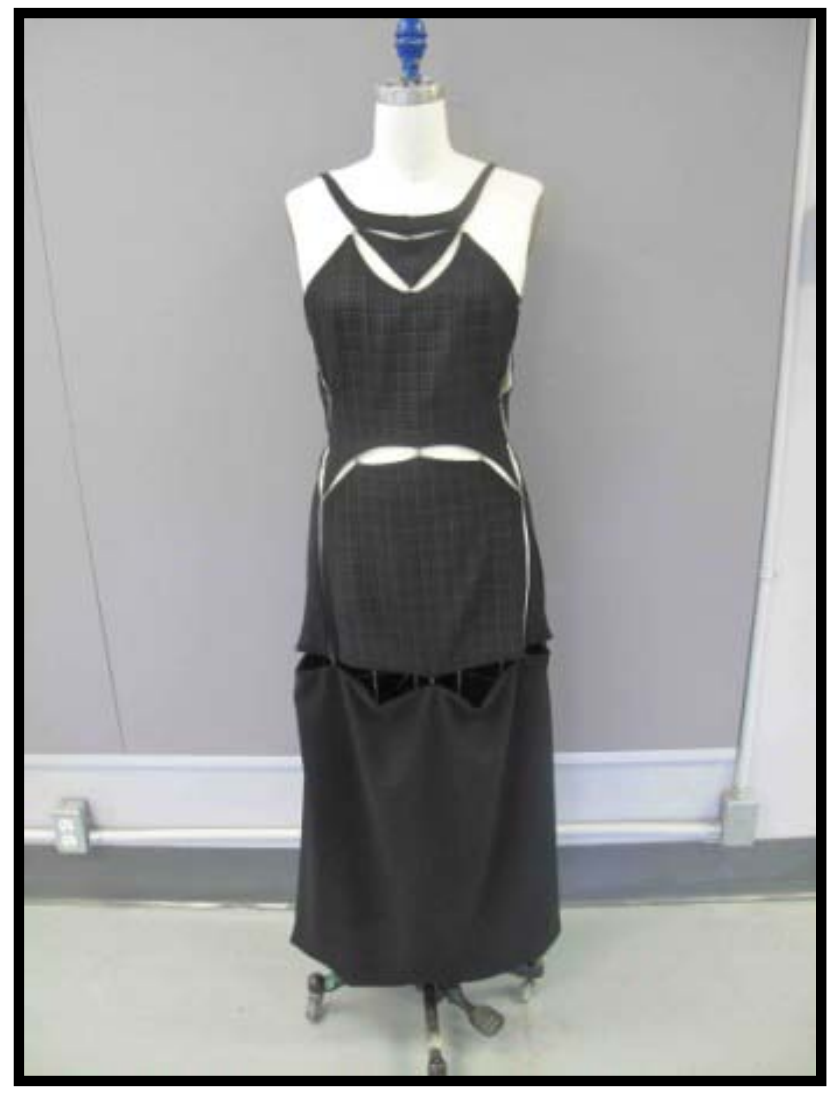

Figure 5.4. Design 2- detachable garment 


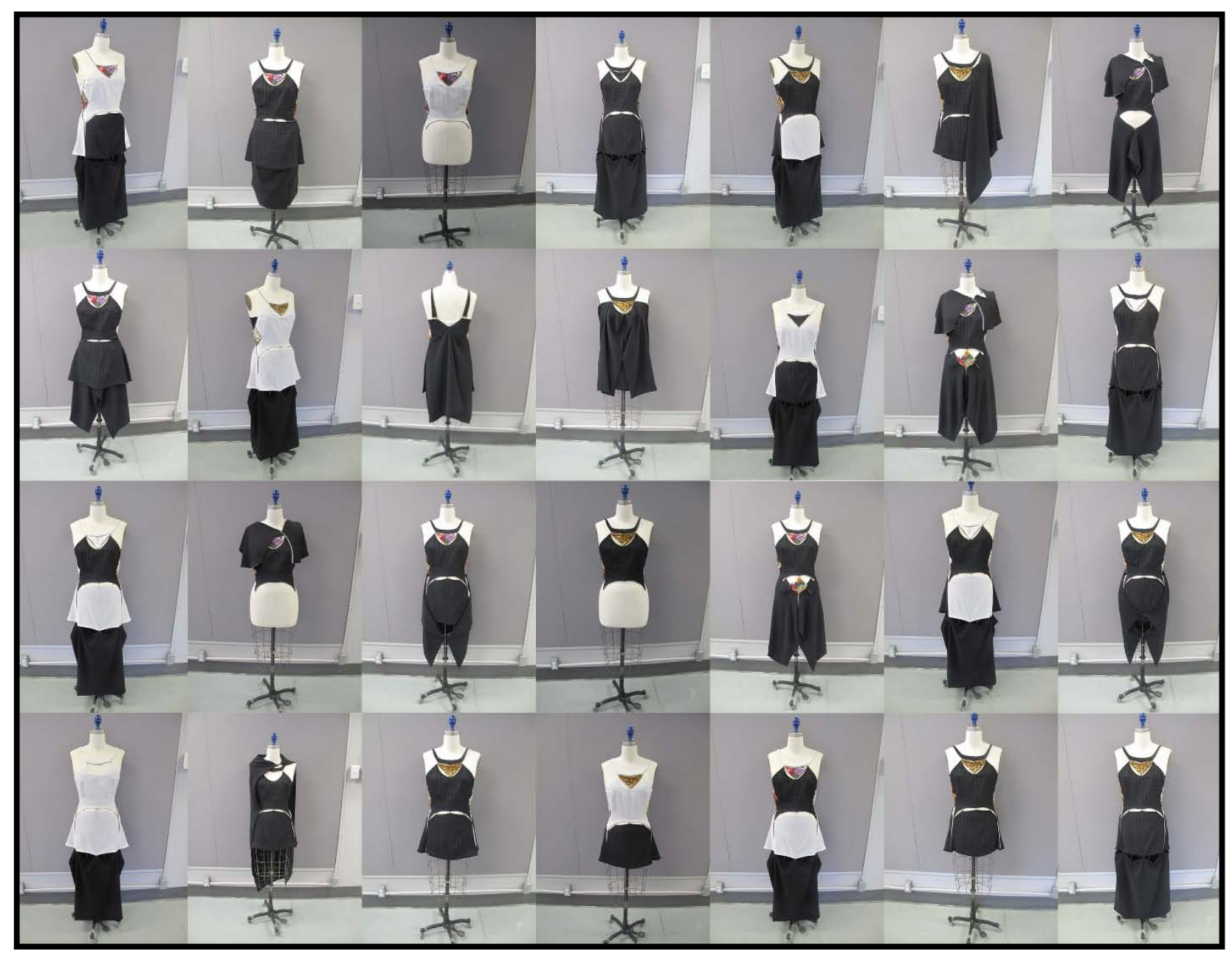

Figure 5.5. Transformable styles of Design 3- Detachable garment

\subsection{Design 3: Transformable Design}

My final design, a modular design, was based on the foundations of the first two designs, drawing from the benefits of experimenting with sustainability, mass production and transformable design concepts. Figure 3.1 illustrates the nonlinearity of the design process, as I moved back and forth between stages to reconsider ideas and come up with a final design solution.

As with the Infinite Dress, Design 3 (transformable garment) is constructed of small fabric components which can be easily separated and recombined. The user can transform the 
garment into a wide variety of styles by detaching or replacing the components. Technologically, it is an advanced version of the Infinite dress as it employs zippers instead of hooks and eyes to connect each fabric piece. For this design, I also used three different kinds of fabrics (leather, knit and cotton) to provide varying garment textures. Design 3 is an improved sustainable fashion design because the connections are more secure, it also offers more diversity of style choices. The garment can be transformed into different styles such as vest, jacket, dress, and jumpsuit, creating more than 300 style options by interchanging 39 fabric pieces.

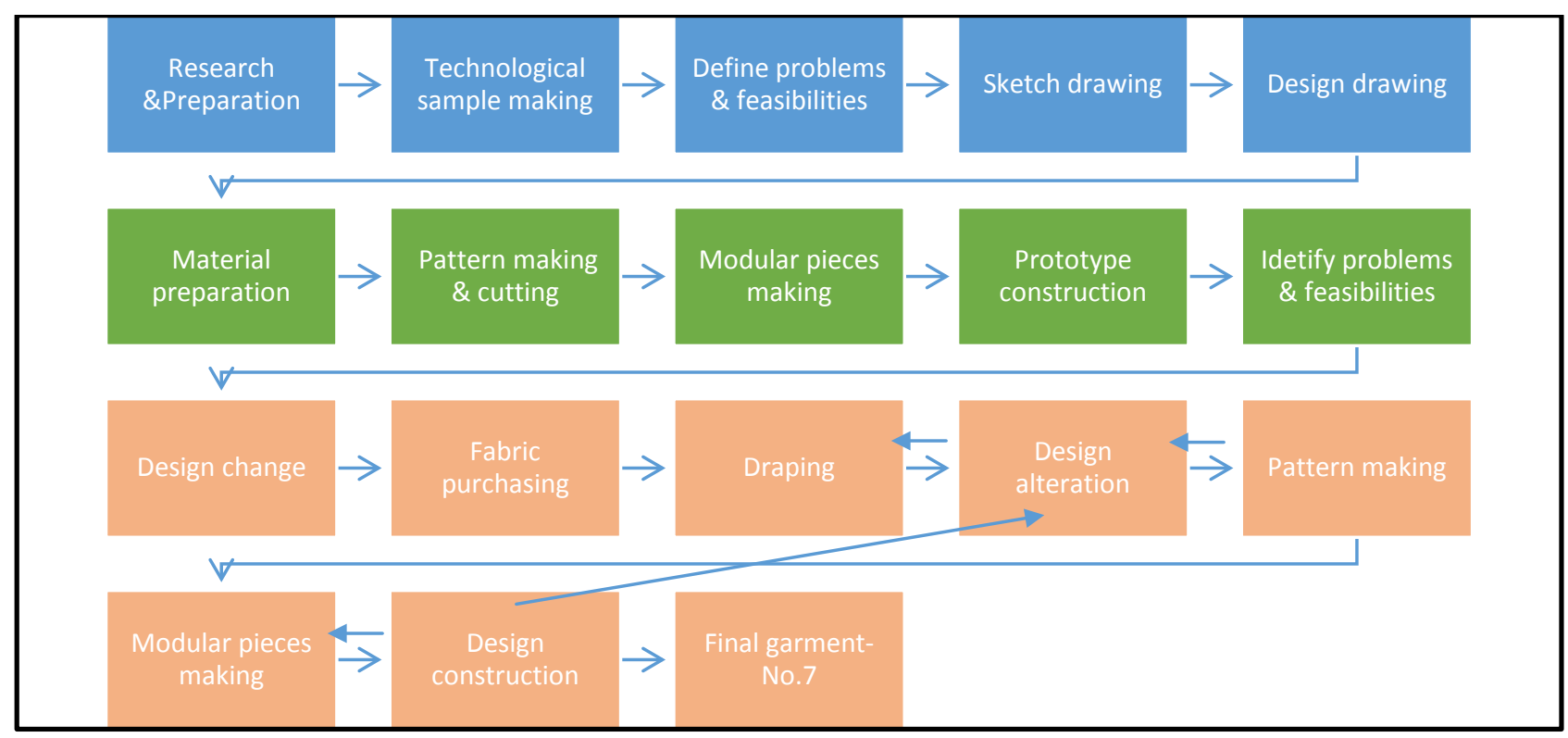

Figure 6. Design processes of Garment3

\subsection{Stage 1: Researching and Purchasing Material}

As mentioned earlier, my previous design experiences comparing different garment closure systems such as Velcro tape, hooks and eyes, and buttons, led me to realize that the zipper was the preferable attachment to use in order to best construct a garment through modular transformable design. This is because the zipper can easily attach two modular pieces, and 
creates a strong seal when it is closed. In my preliminary research of fasteners, I searched for many zipper designs to evaluate their performance. This was one aspect of the general research that I conducted on materials for modular transformable design to help me develop new ideas and anticipate any design issues. However, despite my preparations, unexpected problems with the fasteners occurred during the process of garment construction, and ultimately, I needed to seek out and purchase better zipper components.

4.4.1 Sample making. It was important to thoroughly test the zipper connection technique prior to the garment design and construction process because the utilization of the zipper in this research was an important and challenging experiment. My research revealed that the cross and "T" construction of zipper had not been used before, so it was critical to test this option during the pre-sampling stage. The zipper research and experimentation revealed three key limitations and benefits of the zipper closure:

1. The zipper connection couldn't achieve a T-construction, meaning the zippers could not separate a piece of fabric into three pieces to form a T connection.

2. Though the zipper connection could achieve cross lines, meaning four zippers could be used to separate a piece of fabric into four pieces with a cross-connection, they left a small gap in the middle of the cross (Figure 7.1).

3. Based on the structure of the human body, the separation of garments cannot always be designed in straight lines. Zippers, therefore, are a better solution for designing flat curves.

Compared with regular garment design, modular transformable garment design which uses zippers as connectors can limit structural design possibilities. However, the sample testing shows 
the function of fabric separation and reconnection can be achieved by zippers. And the limitations and problems can be avoided by garment design.

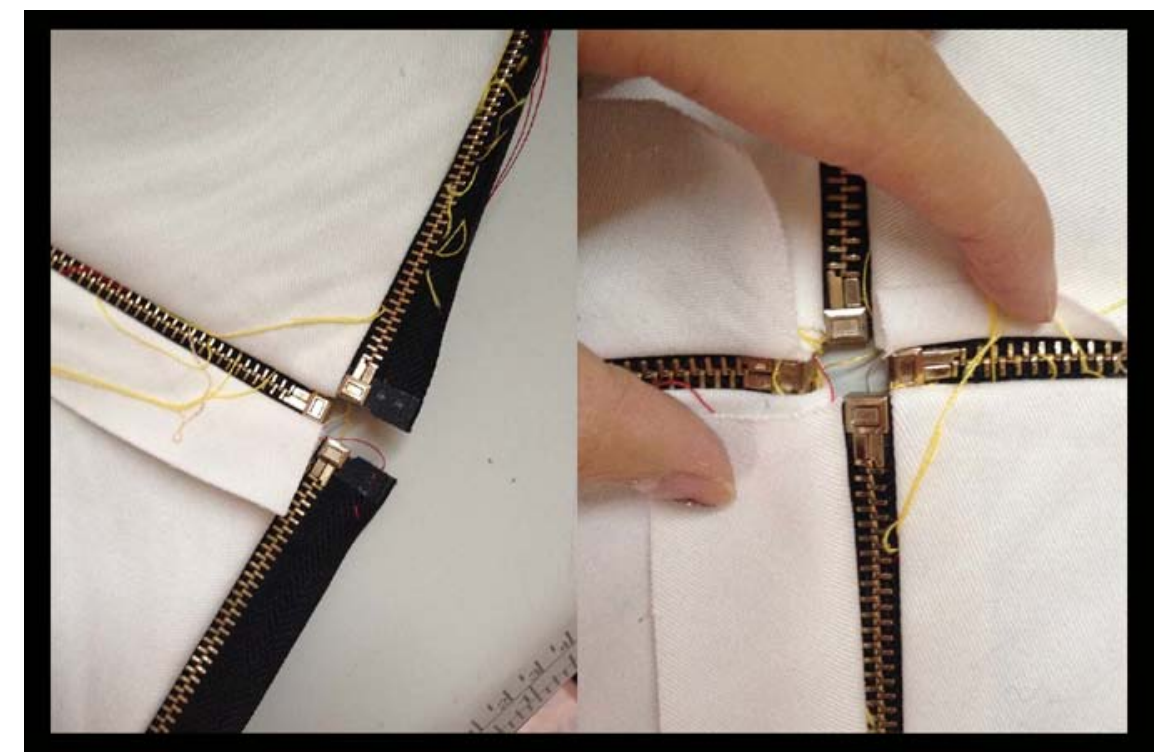

Figure 7.1. Sample making for zipper cross-connection technique

4.4.2 Sketch and design drawing.As Figure 7.2 and 7.3 illustrate, I created several design sketches and 30 design drawings based on my research. All of the designs combined articles of daily clothing items (e.g. vests, dresses, tops and trousers) to create various styles and silhouettes in order to offer choices for a diverse consumer base.

As Figure 7.3 demonstrates (with the exception of the first two drawings) 28 designs feature a separation line on the upper waist. This line reflects a separation point for multiple, interchangeable components. The collection also features designs with other separation points (e.g. sleeve hole line, neck line...) For example, from 3nd to 12th designs are sharing the same structure by detaching, resembling and changing certain modular pieces. 


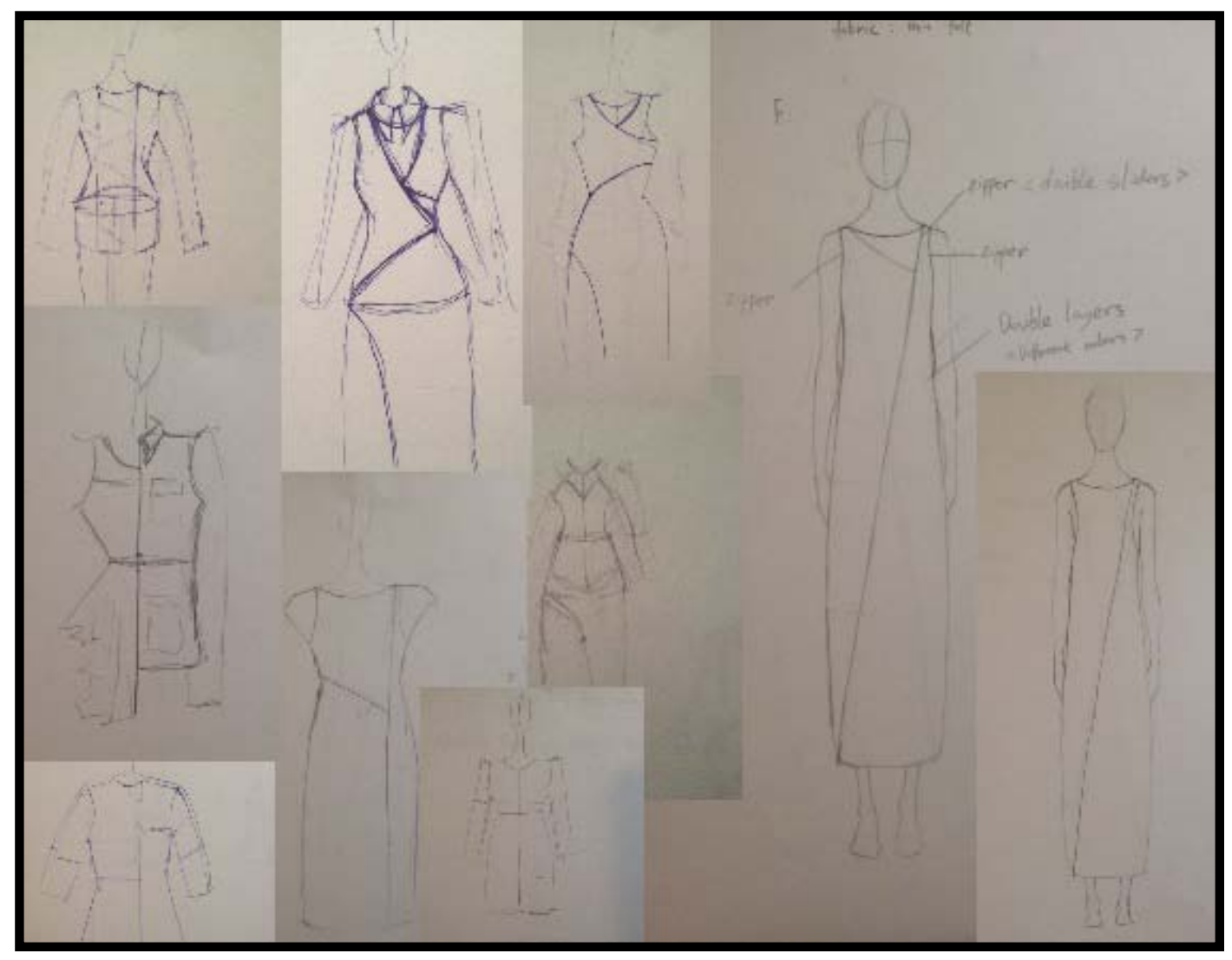

Figure 7.2.Sketches for Design 3 


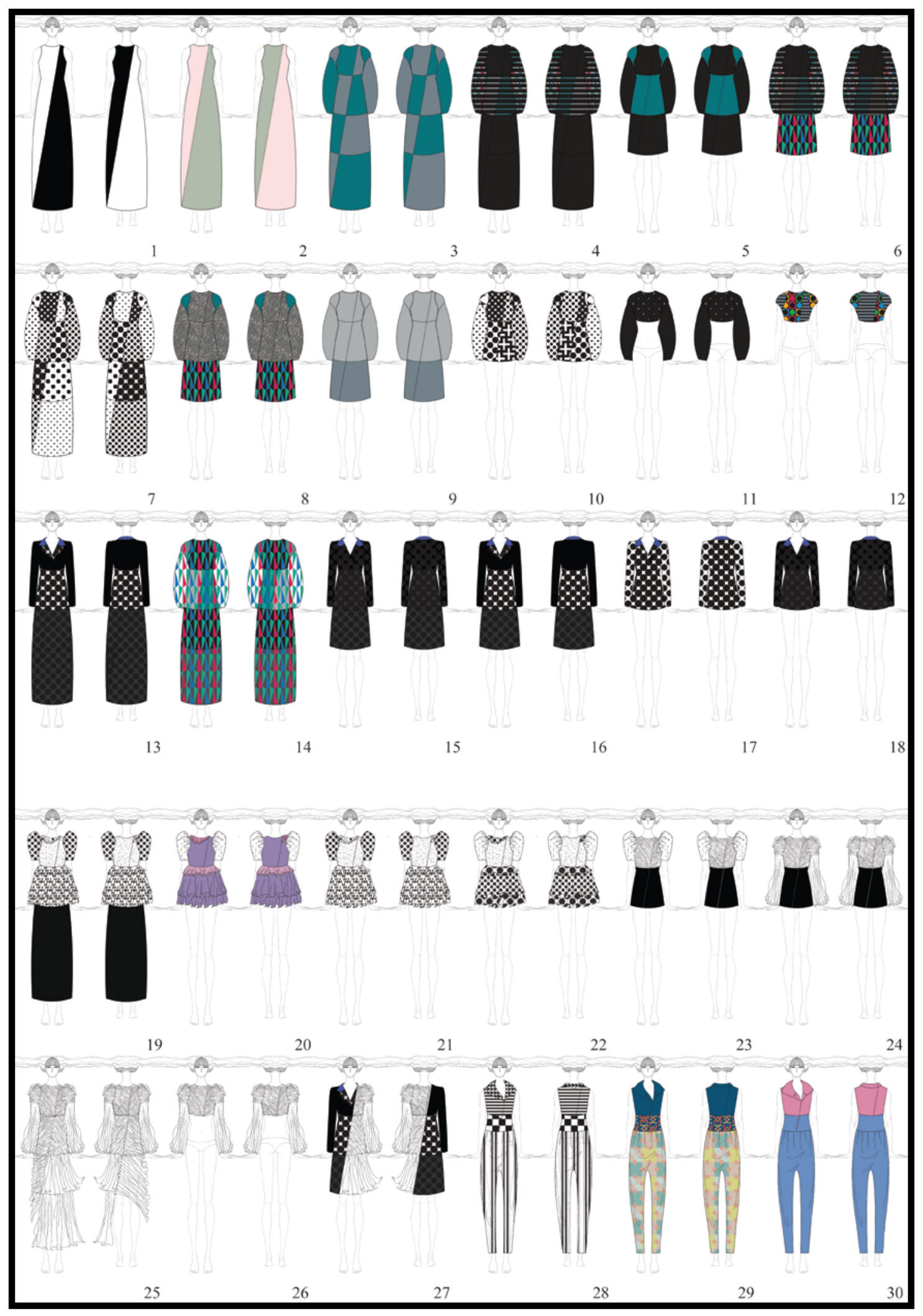

Figure 7.3. Drawings for Design 3 


\subsection{Stage 2: Pattern Making of Design 3}

My first prototype (Garment 3.A) was a black and white version of the third design in Figure 7.3. I chose cotton fabric and metal zippers for this design. From a process of pattern making, modular piece creation and prototype construction, I developed my first garment model (Figure 7.4).

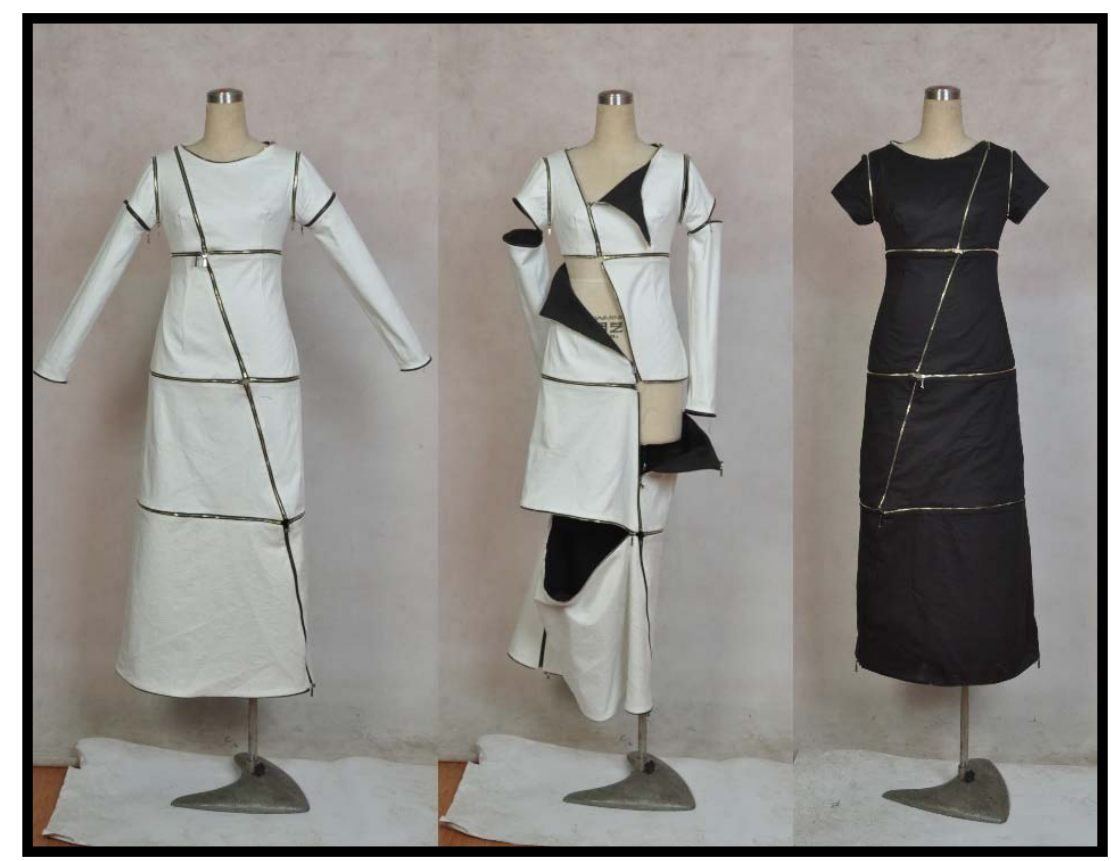

Figure 7.4. Garment 3. A for Design 3-transformable garment

Garment 3.A is comprised of 24 zippers and 12 modular fabric pieces (Figure 7.5). Each modular piece has two layers of fabrics: one side is black and the other is white. One side of a zipper is sewn onto each edge of each modular piece (Figure 7.6). When I developed the prototype, problems arose: First, the cotton fabric was too thin and stiff for the modular pieces with zipper connections. Then, I discovered that the fabric around the zipper cross-connection was uneven, which is because each corner has fabrics double other seams. The fabrics in the corner rose up. 


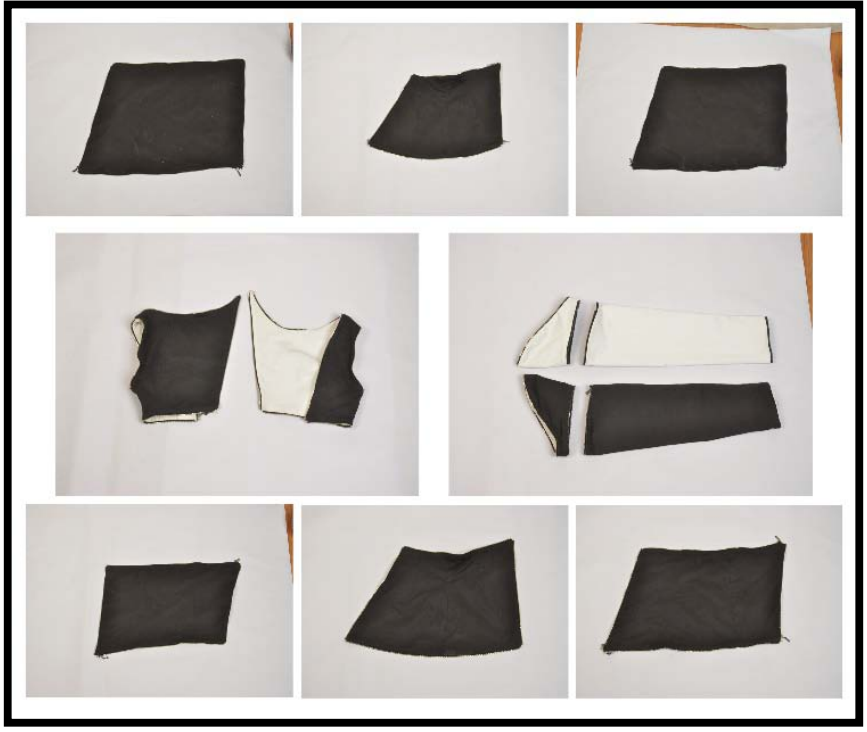

Figure 7. 5. Modular pieces for Garment 3.A

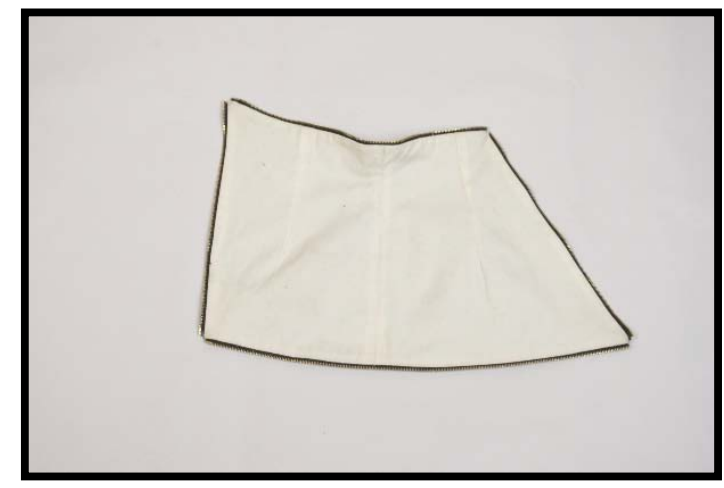

Figure 7.6. Inside layer of a modular piece for Garment 3.A

\subsection{Stage 3: Design Change}

To account for the two problems that developed in stage 2, I needed to revisit and adjust my design drawings. I realized that I had to find a fabric that was thicker and had better elasticity than cotton for this collection. In addition to changing the fabric, I decided to avoid the crossconnection of zippers in my next designs. The pattern making stage revealed that it was a better strategy to separate pieces of fabric with one zipper instead of using multiple zippers to create a cross-connection, to ensure that the fabric surface would remain even. Based on my experiences 
with pattern making in stage 2, I initiated the following design changes. As Figure 7.7 demonstrates, I created design drawings Garment 3.B and Garment 3.C to adjust Garment 3.A.

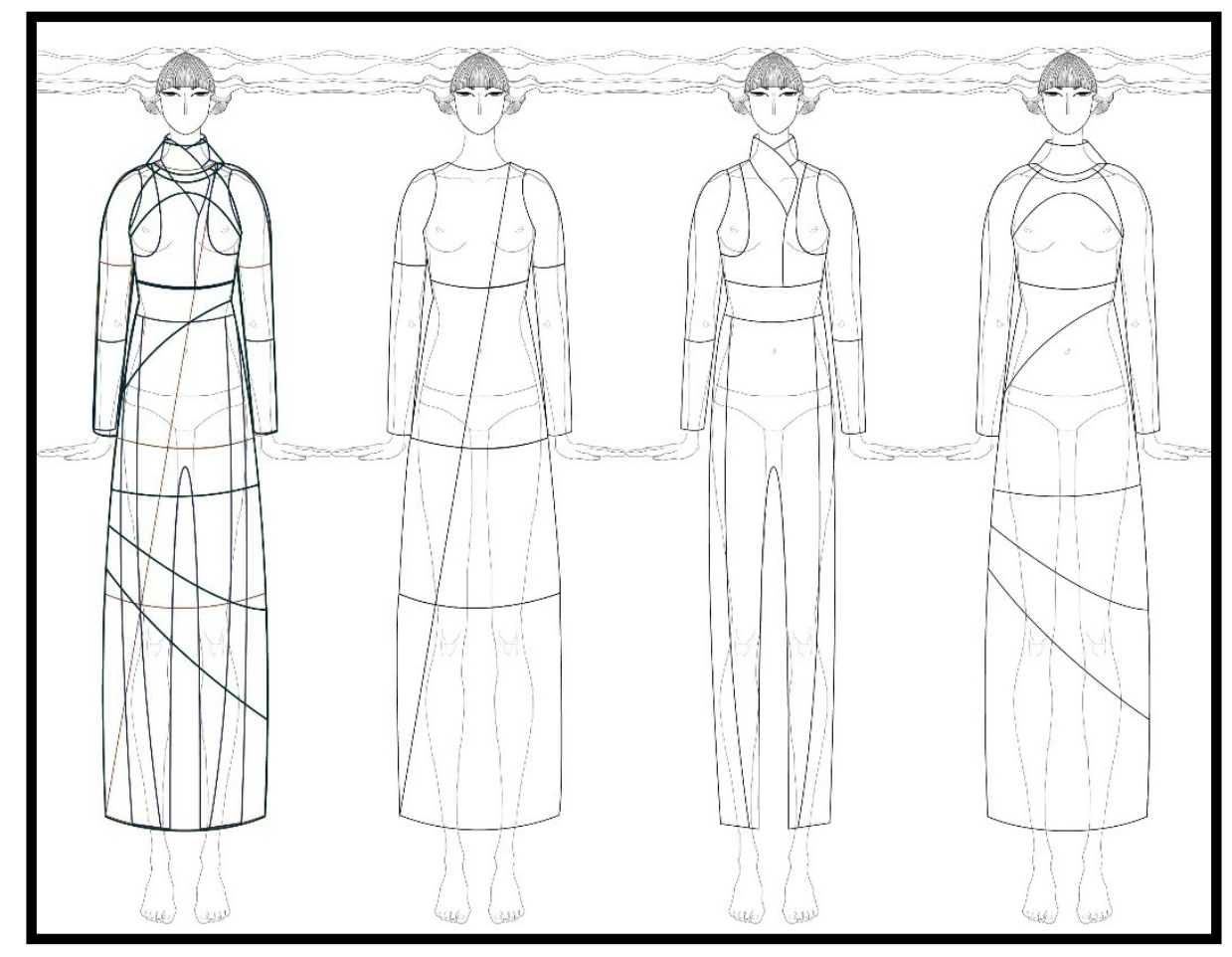

Figure 7.7. (Design 3-3.A; 3.B; 3.C)

These reworked designs differ from Design 3.A in that they avoid the cross-connection of zippers as much as possible and the separation lines of each garment run in the same direction. For example, most of the zippers of Garment 3.B (with the exception of the waist separation line) run vertically. And, in the case of Garment 3.C, the separation lines are mainly horizontal. The three garments maintain the same upper waist separation line, which allows the wearer to interchange the tops and bottoms of each outfit. In addition to the upper waist line, designs 3.A and 3.B have similar armhole lines, meaning sleeves from each separate garment can be interchanged as well. Furthermore, the separation lines of each design use zippers to separate and reconnect, which means that these three garments can be disassembled into several individual fabric pieces. As long as the zippers of each piece have the same length, wearers can change 
individual fabric pieces to reflect different fabrics and styles. Figure 7.8 illustrates the transformative design possibilities of garment 3.B and garment 3.C.

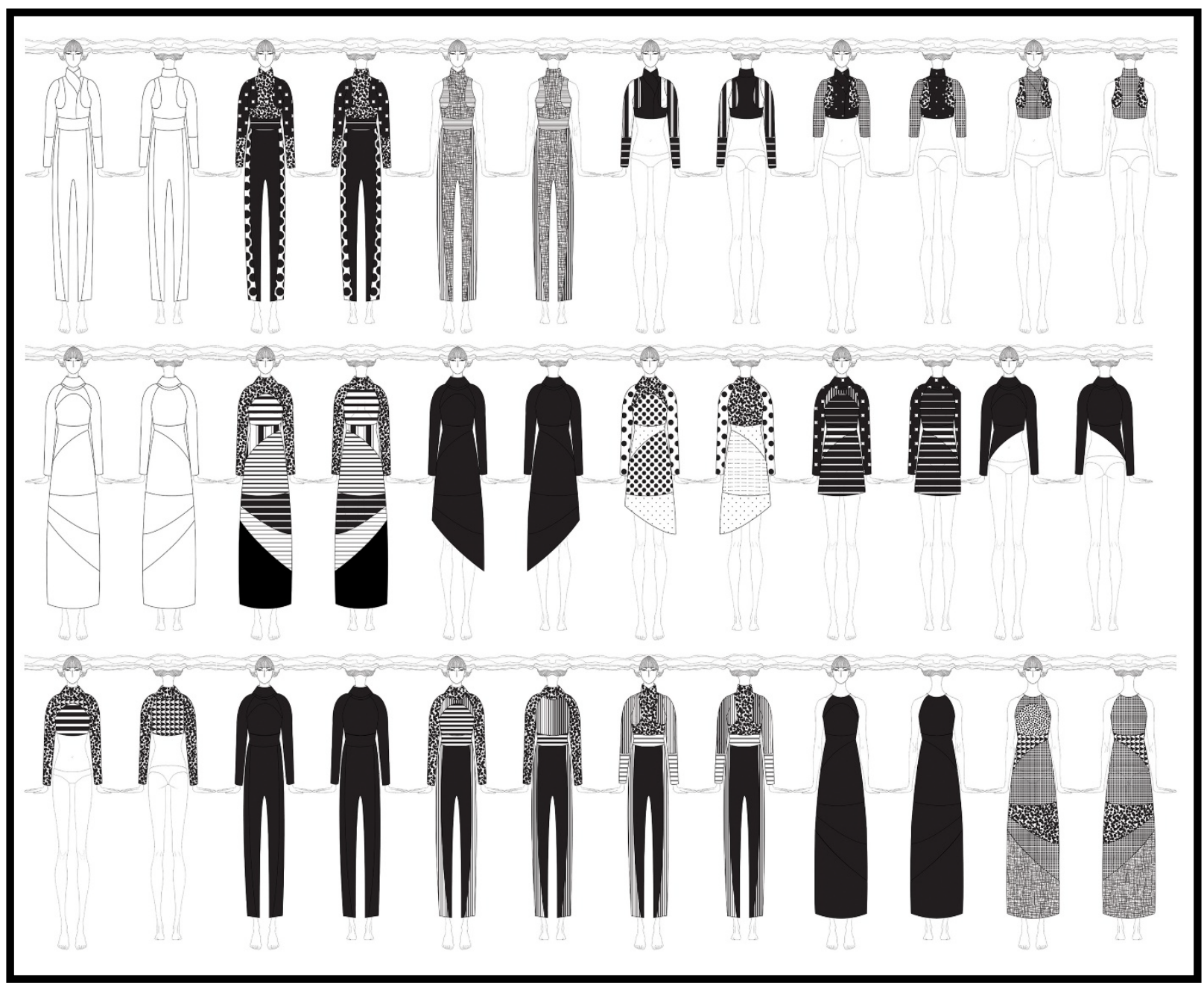

Figure 7.8. Drawings for Garment 3.B \& Garment 3.C 


\subsubsection{Fabric Purchasing}

I constructed the collection in January, 2014, when lots of thick fabrics for the winter season were available in the textile markets; these were exactly the kind of fabrics the designs called for. The main fabrics that I purchased were made of pleated artificial leather and a striped knit (see Figure. 7.9).

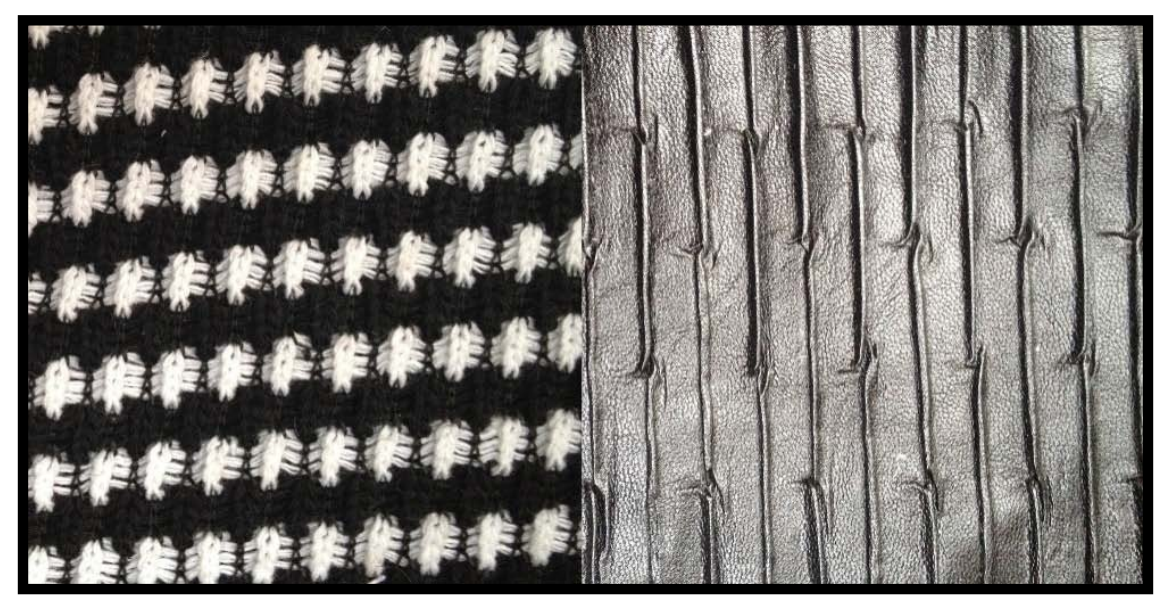

Figure 7.9. Main fabrics for Design 3- transformable garments

I made these fabric purchases for two reasons: the first is that fabrics with elasticity and pleating texture are good for eliminating uneven garment surfaces caused by zipper connections, and the second reason is because metal zippers and leather make a successful and appealing aesthetic combination (as evidenced by the popularity of the well-known fashion brand Vivian Westwood).

\subsubsection{Draping, Design Alteration, Pattern Making and Modular Piece Making}

In Stage 3, 27 modular fabric pieces were produced. As Figure 7.10 demonstrates, these 11 modular fabric pieces could be used to construct Garment 3.B. Eleven other modular pieces made up the construction of Garment 3.C (Figure 7.12). 


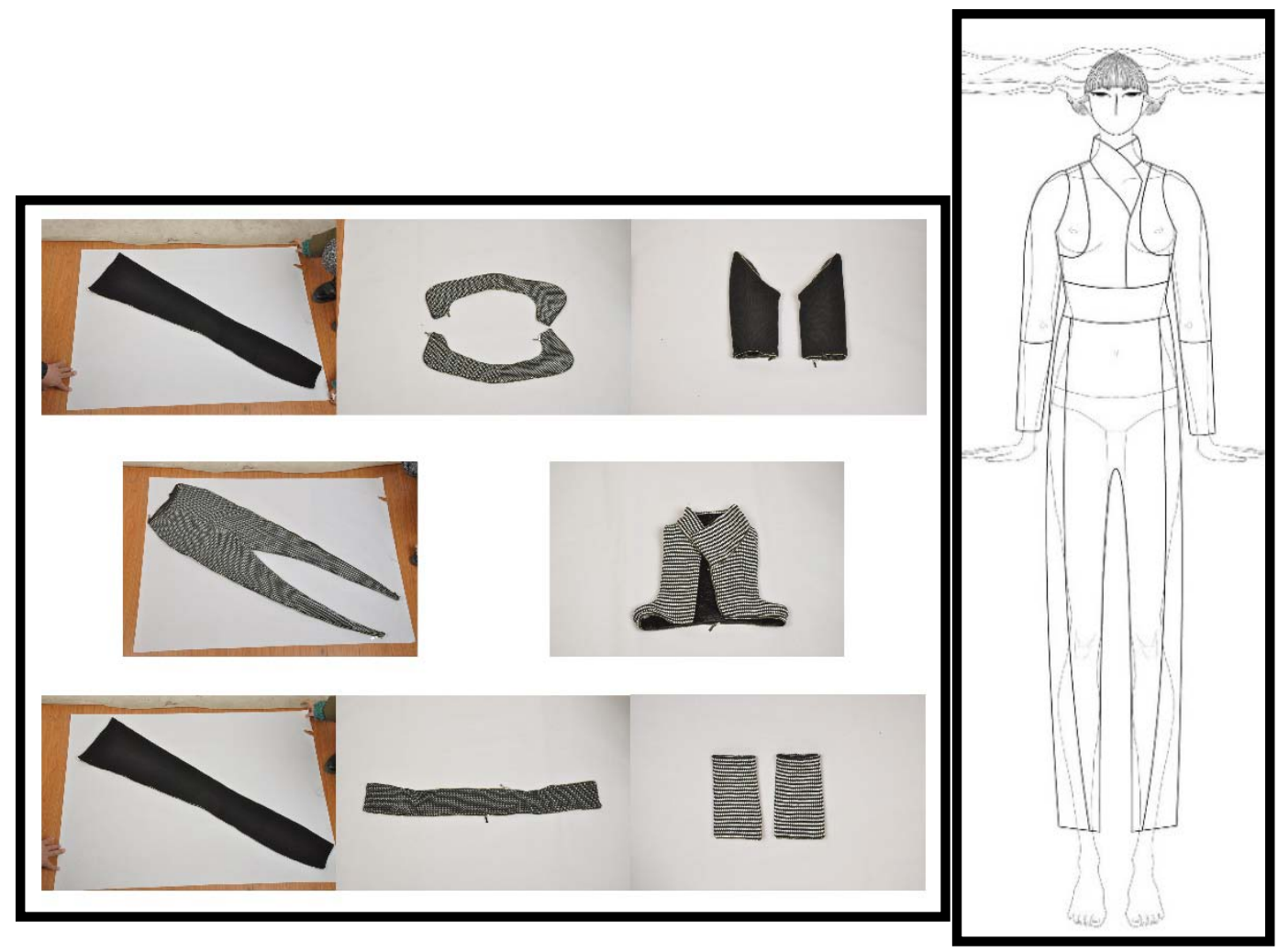

Figure 7.10. Garment modules for Garment 3.B Figure 7.11. Drawings of Garment 3.B

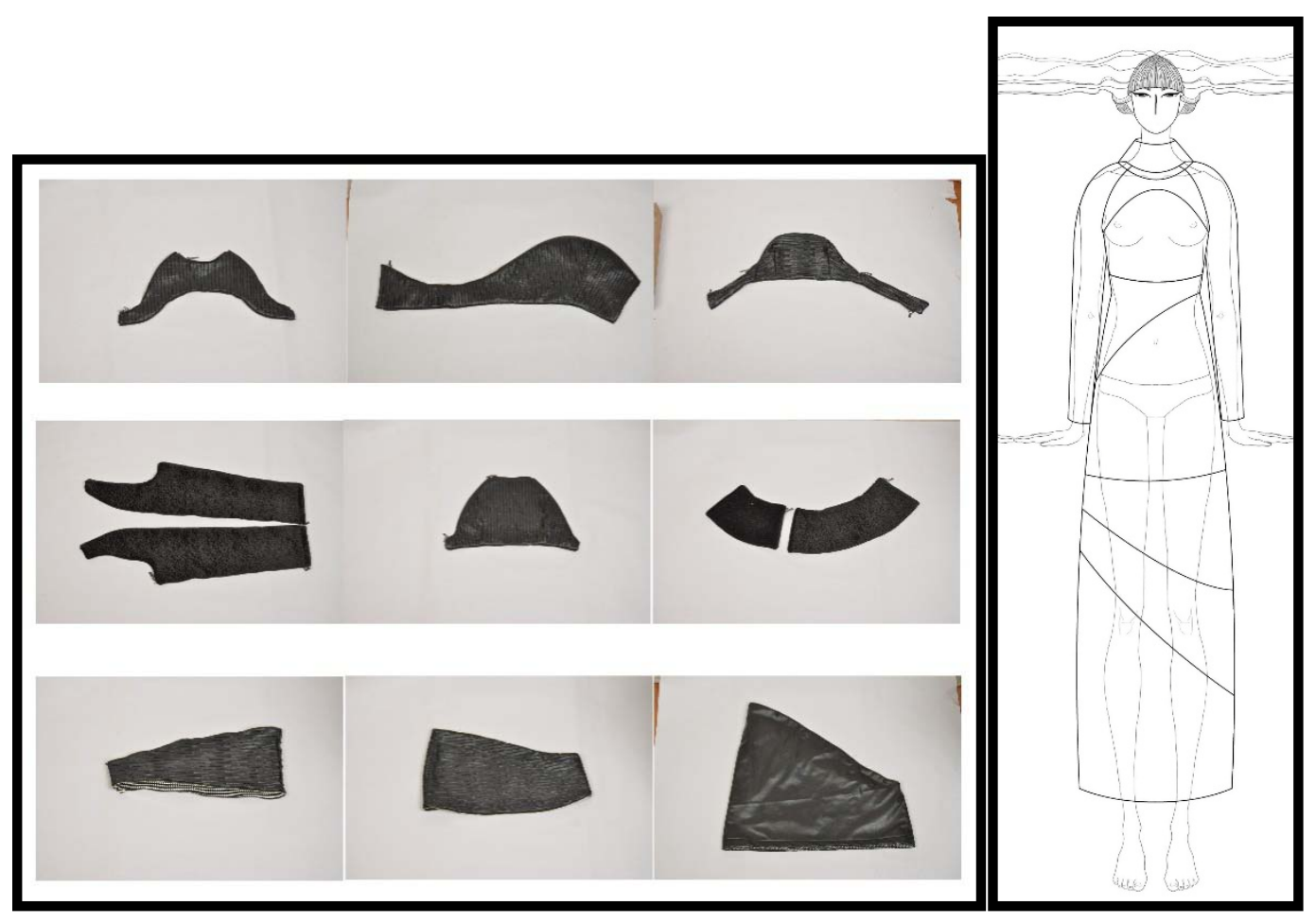

Figure 7.12. Garment modules for Garment 3.C

Figure 7.13. Drawings of Garment 3.C 


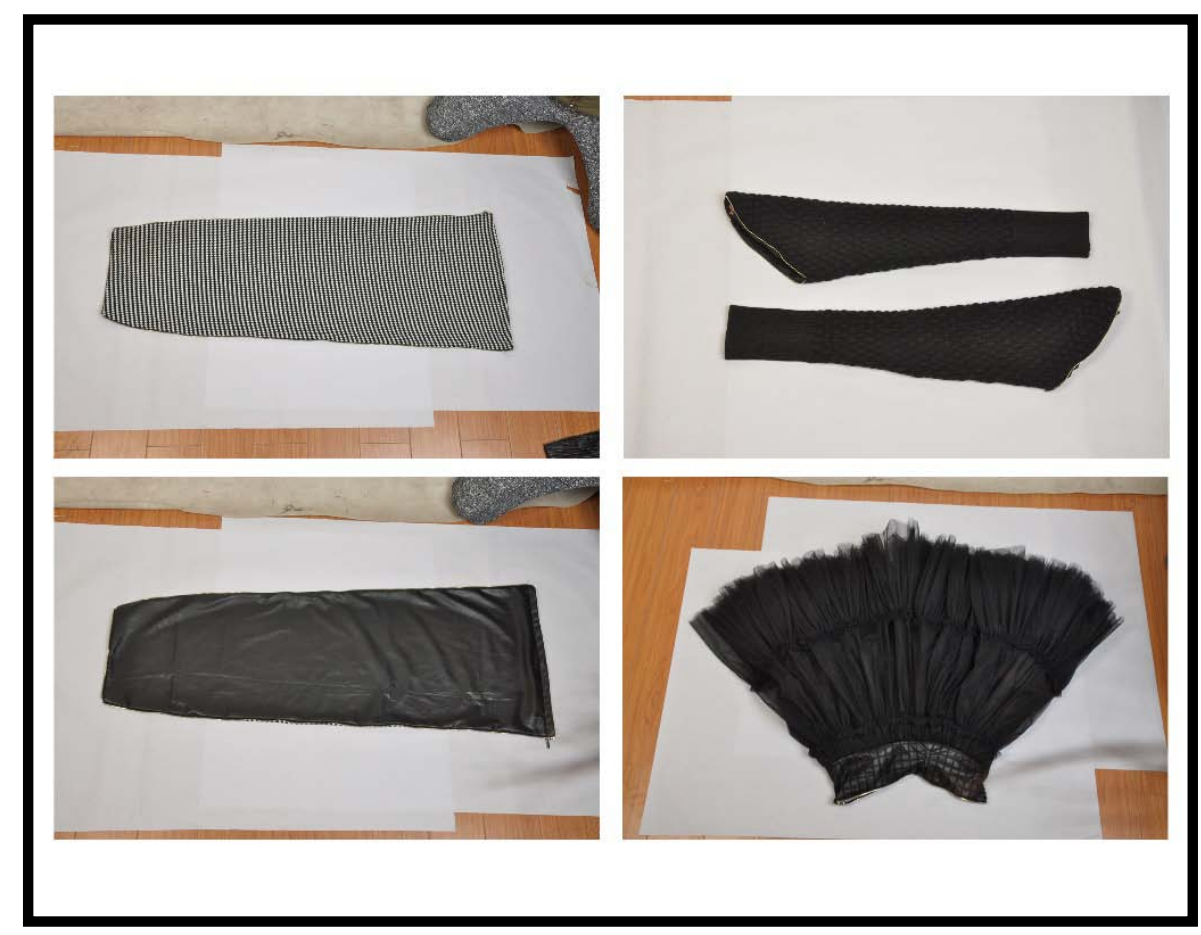

Figure 7.14. Extra pieces for Design 3

Figure 7.14 features five extra pieces: two rectangular pieces of a long dress that can be exchanged with the trousers of Garment 3.C; a pair of knit sleeves which can be exchanged with the sleeves of Garment 3.A and 3.B; and a short dress piece that can be exchanged with all of the bottoms of garments 3.A, 3.B and 3.C. With the exception of the sleeves and the short dress in Figure 7.14, all of the other 24 fabric pieces have two layers: one side is black artificial leather, and the other side is the striped knit.

As previously described, each of the modular fabric pieces has two layers, one which is artificial leather and the other a striped knit. Due to the thickness of the fabric and the measurement requirements for adding a zipper, each modular piece needed to be wider than ten centimeters. To clarify, during the garment production process, pieces with two layers of fabric generally need to turn inside out after the seams are sewed. If the width of a single modular piece is less than ten centimeters, it is difficult to turn the inside fabric out. This issue means that the 
two separation lines on the garment cannot be closer than ten centimeters. This very problem occurred in the modular piece-making phase, which forced the production process back and, as a result, I had to return to the designing phase to make alterations.

Design construction.In this collection, I had to go back and forth to alter designs not only during the garment design and modular piece making phases, but after the design construction, as well. For instance, Figure 7.16 provides a look at the construction of Garment 3.C in progress to demonstrate how well the zipper connections work here.

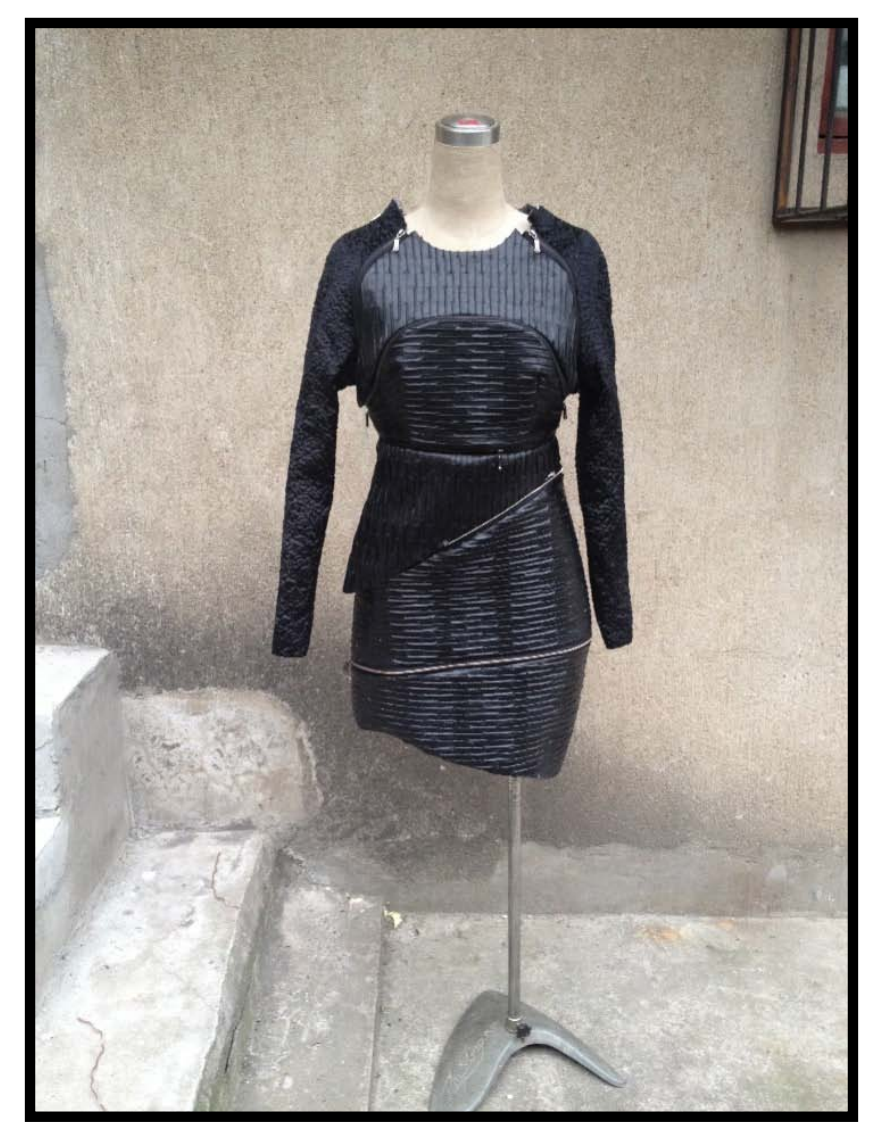

Figure 7. 15. Design in progress of Garment 3.C

However, following the principles of interchangeable garment design, the top of Garment 3.C should be able to connect with the bottom of Garment 3.A and 3.B. A problem 
occurred when the top of garment 3.C did not connect with the bottom of Garment 3.A. As Figure 7.17 illustrates, one of the zippers on the bottom of Garment 3.A could not be closed while connecting it with the top of Garment 3.C.

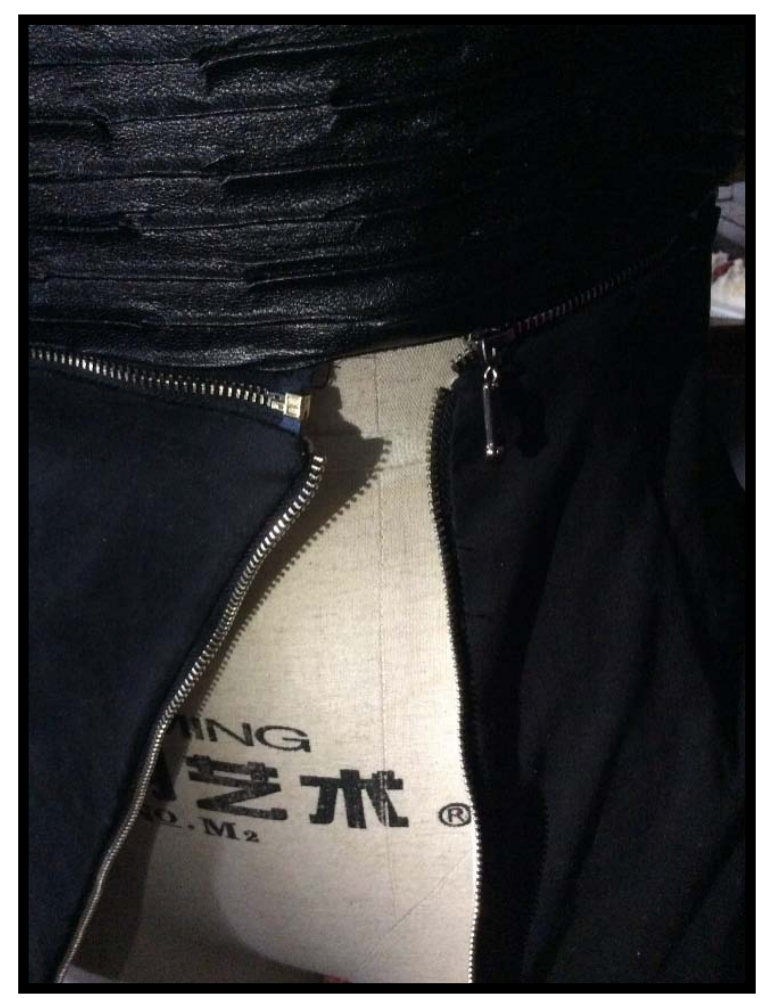

Figure 7.16. Errors occurred with parts connection of Garment 3.A and Garment 3.B

Two sides of the zipper length were different even though the separation line was the same and the pattern making was based on the same size. This issue identified a sewing error that occurred when pieces with two different fabric thicknesses were assembled. This error also resulted in my having to go back to both the pattern making and modular piece making phases in order to resolve the problem. 


\section{Final Design 3}

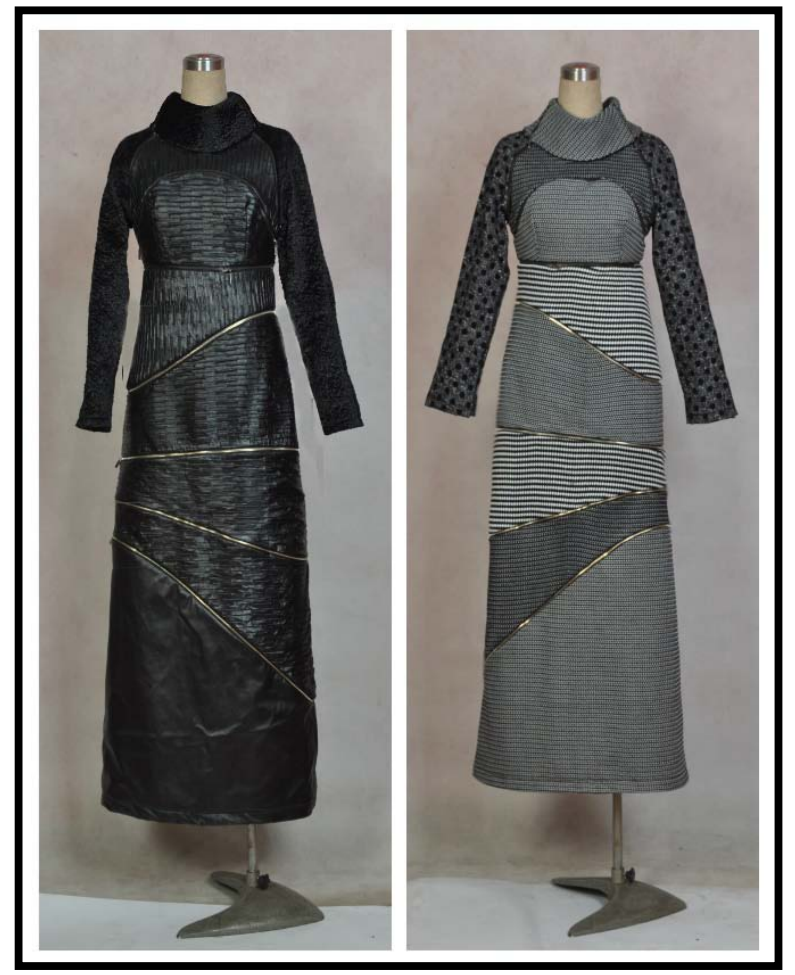

Figure 7.17. Garment 3.C-transformable garment

Figure 7.17 represents the completed creation, Garment 3.C. The completed garments fully demonstrate how the zipper connection can open up unlimited design possibilities for transformable fashion. The constructed modular pieces can be easily disassembled into individual pieces that the wearer may separate, reconnect, exchange and use again. As shown in figure 7.18-7.20, various styles were constructed by exchange certain modular. The intention of the Garment 3 design was to provide as many design possibilities for the consumer as possible by using limited modular pieces. While the final designs may prove to be too complex for daily wearing, I suggest that this project in experimental garment design has the flexible capabilities of this design method. The objective in creating Garment 3 was not only to demonstrate the ways three basic garments can transform into hundreds of styles, but to explore a new design method that can be adapted and utilized in a wide variety of garment designs. 


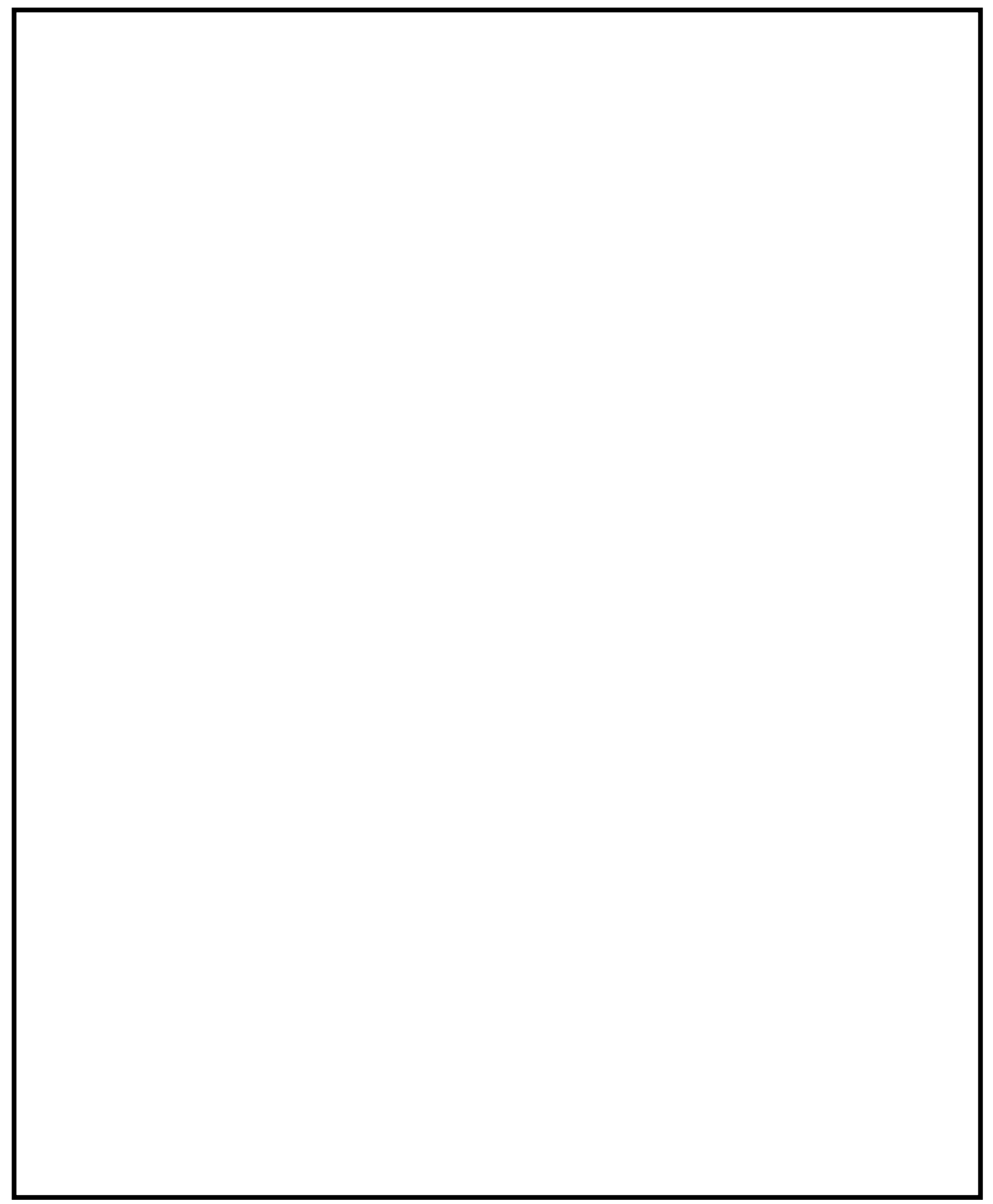

Figure 7.18. Transformable styles of Design 3 


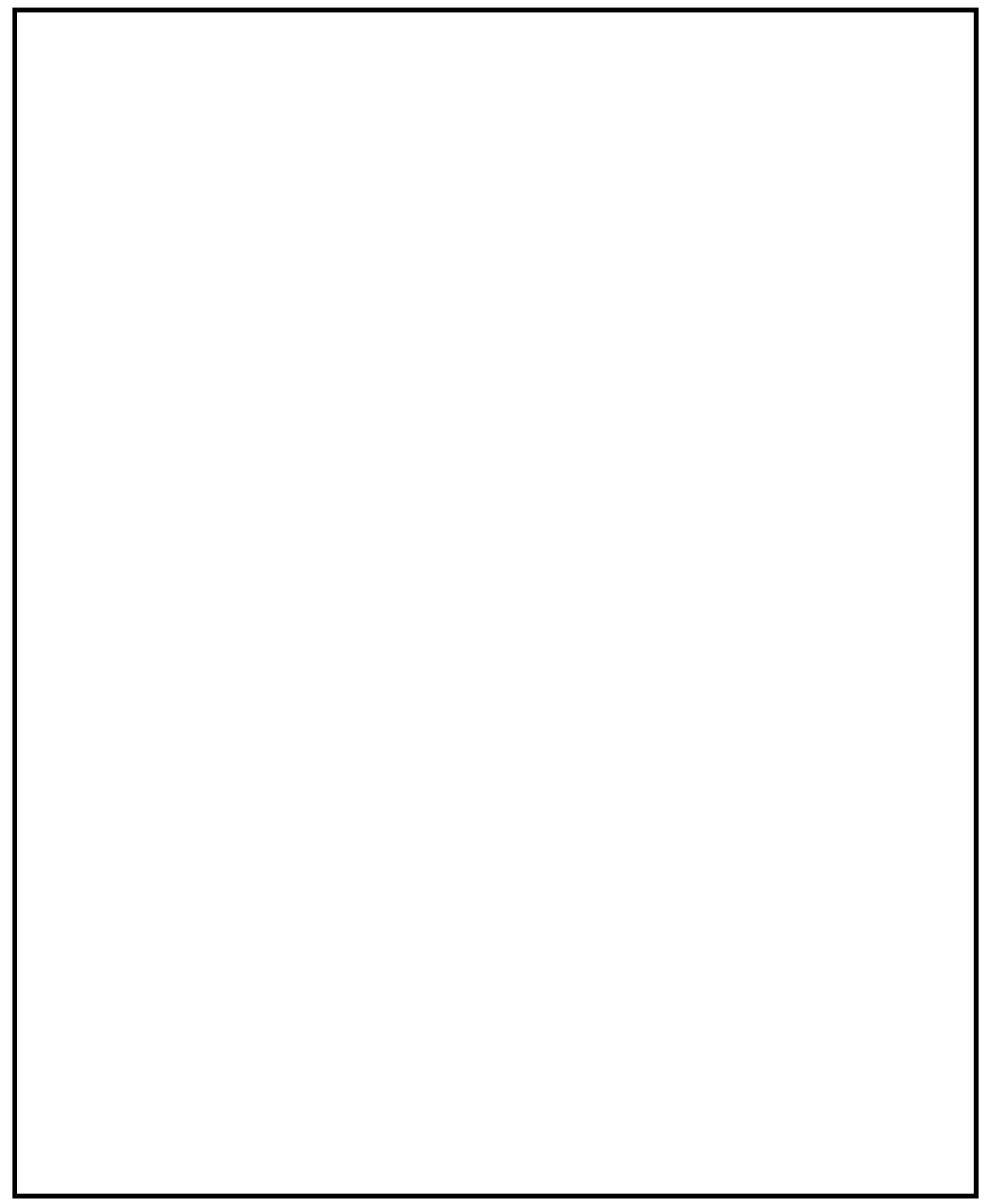

Figure 7.19. Transformable styles of Design 3 


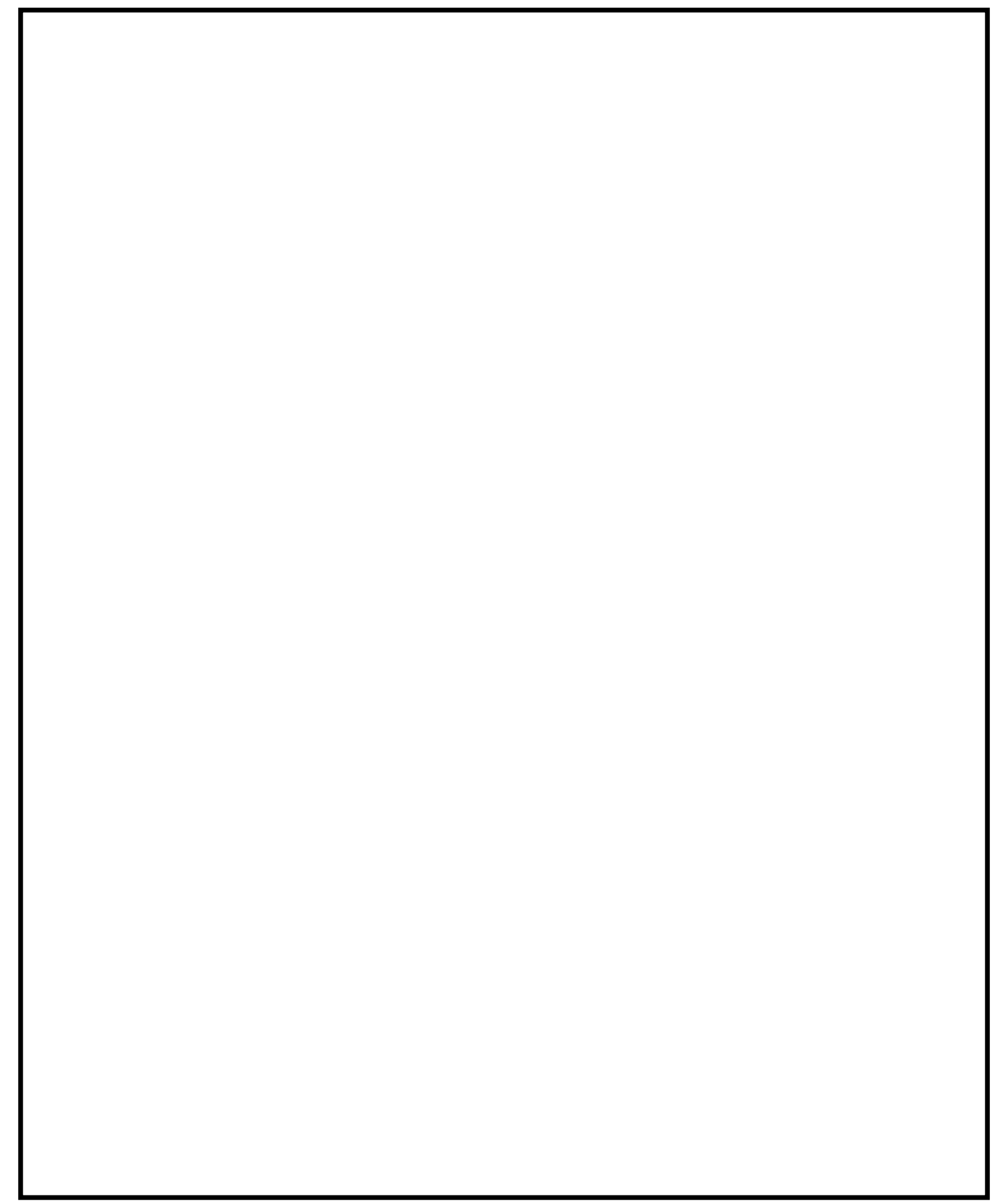

Figure 7.20. Transformable styles of Design 3 


\section{Chapter 5}

\section{Research Findings}

\subsection{Interviews}

For the interviews, I approached seven fashion industry experts: entrepreneurs E1 and E2 ${ }^{3}$, the founders of two apparel companies; entrepreneur E3, the chairman of a manufacturing company; P1 and P2, professors of Soochow University; and D1and D2, fashion designers. Through these interviews, I hoped to uncover the underlying views of fashion insiders and gain their insights into sustainable fashion, transformable garments, and my Garment design 3.

\begin{tabular}{|c|c|c|c|c|c|c|c|}
\hline Profile & $\begin{array}{l}\text { Experience } \\
\text { in Fashion } \\
\text { Industry }\end{array}$ & Gender & $\begin{array}{l}\text { City of } \\
\text { Residence }\end{array}$ & Occupation & $\begin{array}{l}\text { Number of } \\
\text { Employees }\end{array}$ & $\begin{array}{l}\text { Year } \\
\text { Company } \\
\text { Established }\end{array}$ & Products \\
\hline E1 & 12 years & Male & Shenzheng & $\begin{array}{l}\text { Owner of Wan } \\
\text { company }\end{array}$ & around 20 & 2002 & $\begin{array}{l}\text { Middle aged } \\
\text { women's wear }\end{array}$ \\
\hline E2 & 13 years & Female & Shenzheng & $\begin{array}{l}\text { Owner of Siji } \\
\text { company }\end{array}$ & $20-30$ & 2000 & $\begin{array}{l}\text { Middle aged } \\
\text { women's wear }\end{array}$ \\
\hline E3 & $\begin{array}{l}\text { More than } \\
30 \text { years }\end{array}$ & Female & Nantong & $\begin{array}{l}\text { Owner of Nantong } \\
\text { Vanwell Garments } \\
\text { Co., Ltd. }\end{array}$ & over 500 & 2003 & $\begin{array}{l}\text { Manufacturing, } \\
\text { cooperate with } \\
\text { top brands such } \\
\text { as Burberry, } \\
\text { CK, Le coq } \\
\text { sportif }\end{array}$ \\
\hline $\mathrm{P} 1$ & 21 years & Female & Suzhou & $\begin{array}{l}\text { Professor in } \\
\text { Soochow Universty }\end{array}$ & & & \\
\hline $\mathrm{P} 2$ & 17 years & Female & Suzhou & $\begin{array}{l}\text { Professor in } \\
\text { Soochow } \\
\text { University }\end{array}$ & & & \\
\hline D1 & 1 year & Female & Nanjing & $\begin{array}{l}\text { Designer of } \\
\text { Jiangsu Ever-glory } \\
\text { International Group } \\
\text { Corporation }\end{array}$ & & & \\
\hline D2 & 2 years & Female & Hongkong & $\begin{array}{l}\text { Designer of Neo- } \\
\text { Concept Group } \\
\text { LTD }\end{array}$ & & & \\
\hline
\end{tabular}

Table 1. Informant Profiles(E1, E2, E3: Entrepreneurs; P1, P2: Professors; D1, D2: Designers)

\footnotetext{
${ }^{3}$ The alphanumeric identifiers in this chapter stand as pseudonyms for the research participants to protect their anonymity
} 
5.1.1 Sustainable fashion. The participants in these interviews were asked to state their personal opinion about sustainability in the Chinese fashion industry. Participant P1 proposed that consumer acceptance of sustainable fashion depended on their education level, financial capabilities and living styles. She suggested that educated consumers were more likely to consider the long-term benefits of their purchases and would buy sustainable products, whereas consumers with a lower education only considered the short-term benefits without a concern for sustainability. Participants P2, E1, and D1 reported that environmental issues related to the fashion industry in China are regulated by the government, and that fashion and textile companies must follow certain rules and policies to avoid environmental pollution in garment and textile dyeing processes. They suggested that most companies are unwilling to expend extra human resources and materials to achieve sustainability after they have met the basic environmental requirements from the government. The priority for most Chinese companies is profit maximization, and in the fashion industry, environmental garment production increases costs without providing concrete benefits for businesses.

Participants of entrepreneur and designer also stated that they would choose sustainable solutions only if the cost of implementing them remained the same as traditional methods. Participant E1 explained that this attitude is common in the current Chinese fashion market because everyone focuses on producing new and creative designs without seeing a need for sustainability. However, six out of the seven participants believed that this perspective will change, and that fashion producers will come to value sustainability in the near future. 
5.1.2 Transformable design. In regards to the participants' interest in and engagement with transformable fashion design, three participants stated that they had designed or produced transformable garments in the past, and their opinions on the subject were quite different. Participant E2 thought that transformable design was inconvenient for both consumers and producers, from both the wearing and production aspects. She believed that structural integrity is important to garment designs, and original designs provided the best looks, stating: “A garment is designed as a united whole, if you change parts of the design or transform it to another style, it will look bad.” From this company owner's perspective, there was no need for transformable design.

Participant E1 also claimed that contemporary Chinese consumers prefer to purchase two different garments instead of one transformable garment with two styles. He believed "new" garments (meaning new designs and products) were most important in current Chinese fashion. E1 also reported that he had experience producing a transformable garment that could be worn two ways. He thought that consumers only purchased the garment because they liked one of the two styles, and felt that mostly, consumers did not care about the transformable feature. E1 revealed that the production costs of the transformable garment increased by $15 \%$, meaning that he had to increase the sale price, and that there was no obvious change in sale volume. Therefore profits of the transformable design remained stable.

Alternatively, Participant D1 had a positive experience with transformable design production, and claimed that it did appeal to her customers. She related that she had produced a variety of transformable designs, including winter garments with removable hats and fur decorations, garments with transformable sleeves, tops with detachable skirts, and that all of them had resulted in strong sales. 
5.1.3 Participant responses to garment Design 3.In his evaluation of the garment Design 3, Participant E1 suggested that it could be more creative from an aesthetic perspective. He believed aesthetics was the most important principle of fashion design, and that designers could not sacrifice style to achieve sustainability. Participants P1 and P2 thought that Design 3 was as good design concept, but that it needed to be simplified before it was put on the market, as one garment with hundreds of styles provided too many options for the consumer in their daily wear choices. They also suggested that using metal zippers as the main connection was not a good choice because they could be uncomfortable when it directly contacts with human skin.

Participant D2 claimed cost performance was an essential element when a consumer purchased goods. Transform options and production cost need to be balanced. It would be ideal to maximize transform options while minimize production cost.

\subsection{Online Survey}

In addition to obtaining opinions from fashion insiders, I felt it was important to understand both consumers’ attitudes toward sustainability, customization, and transformable garments and their needs and requirements for such products. Therefore, I developed and conducted an online questionnaire to gain insight into these issues from fashion consumers.

5.2.1 Basic demographics. The survey was open to both women and men $(76.5 \%$ females and 23.5\% males), and the mean age of the respondents ( $\mathrm{N}=115$ ) was approximately 20 years old. The largest participant age group was between 20-30 years old (50.9\%), and the second largest group was comprised of 10-20 year olds (47.3\%). The majority (75.7\%) had received an undergraduate degree, $15.9 \%$ had achieved graduate level education, $5.6 \%$ had only attended high school, and $2.8 \%$ had college training experience. The survey covered consumers from 19 provinces of China, with a majority of 54.7\% residing in Hubei province. 


\begin{tabular}{|c|c|c|}
\hline & Response Percentage & Response Count \\
\hline \multicolumn{3}{|l|}{ Age } \\
\hline \multirow{4}{*}{$\begin{array}{l}10-20 \\
20-30 \\
30-40 \\
40-50\end{array}$} & 0.466 & 54 \\
\hline & 0.517 & 60 \\
\hline & 0.009 & 1 \\
\hline & 0.009 & 1 \\
\hline \multicolumn{3}{|l|}{ Gender } \\
\hline \multirow{2}{*}{$\begin{array}{l}\text { Male } \\
\text { Female }\end{array}$} & 0.242 & 29 \\
\hline & 0.758 & 91 \\
\hline \multirow{5}{*}{$\begin{array}{l}\text { Education Level } \\
\text { High School } \\
\text { College } \\
\text { Undergraduate } \\
\text { Graduate }\end{array}$} & & \\
\hline & 0.062 & 7 \\
\hline & 0.035 & 4 \\
\hline & 0.743 & 84 \\
\hline & 0.159 & 18 \\
\hline \multicolumn{3}{|l|}{ Occupation } \\
\hline \multirow{7}{*}{$\begin{array}{l}\text { Government employee } \\
\text { Human resources } \\
\text { Manufacturer } \\
\text { Business and Financial } \\
\text { Teacher } \\
\text { Student } \\
\text { Artist }\end{array}$} & 0.017 & 2 \\
\hline & 0.068 & 8 \\
\hline & 0.017 & 2 \\
\hline & 0.034 & 4 \\
\hline & 0.009 & 1 \\
\hline & 0.701 & 82 \\
\hline & 0.051 & 6 \\
\hline \multicolumn{3}{|l|}{ Monthly Income } \\
\hline \multirow{5}{*}{$\begin{array}{l}1500 \\
1500-3000 \\
3000-5000 \\
5000-10,000 \\
10,000-50,000\end{array}$} & 0.589 & 66 \\
\hline & 0.188 & 21 \\
\hline & 0.134 & 15 \\
\hline & 0.063 & 7 \\
\hline & 0.027 & 3 \\
\hline \multicolumn{3}{|c|}{ Monthly Average Consumption on } \\
\hline \multirow{7}{*}{$\begin{array}{l}\text { Clothing } \\
0-100 \\
100-300 \\
300-700 \\
700-1500 \\
1500-3000 \\
3000-5000 \\
5000-10000\end{array}$} & 0.059 & 7 \\
\hline & 0.314 & 37 \\
\hline & 0.305 & 36 \\
\hline & 0.246 & 29 \\
\hline & 0.042 & 5 \\
\hline & 0.025 & 3 \\
\hline & 0.017 & 2 \\
\hline
\end{tabular}

Table 2: Online Respondents’ Demographics

5.2.2 Experimental design experiences. At the beginning of the survey, I created an experimental co-design section in which participants could design their own garment in three different stages. The experimental design section utilized drawings of Garment 3 and provided design choices using the modular fabric pieces that were created for this garment. The options 
included two top modular pieces for Stage 1, twenty-four waist modular pieces for Stage 2, and ten sleeve choices for Stage 3 (Figure 8, Figure 9). One hundred and twenty participants engaged in this design section, and created 192 design results. Thirty-four participants submitted their designs more than twice. As the Figure 10 demonstrates, 54.41\% of the participants chose knit as the major fabric of their design, and $45.59 \%$ chose leather. Components of 1, 12, 22 in step two and sleeve styles of 2, 3 and sleeveless in step 3 are the top selected styles (see Figure 8, Figure 9, and Figure 10).

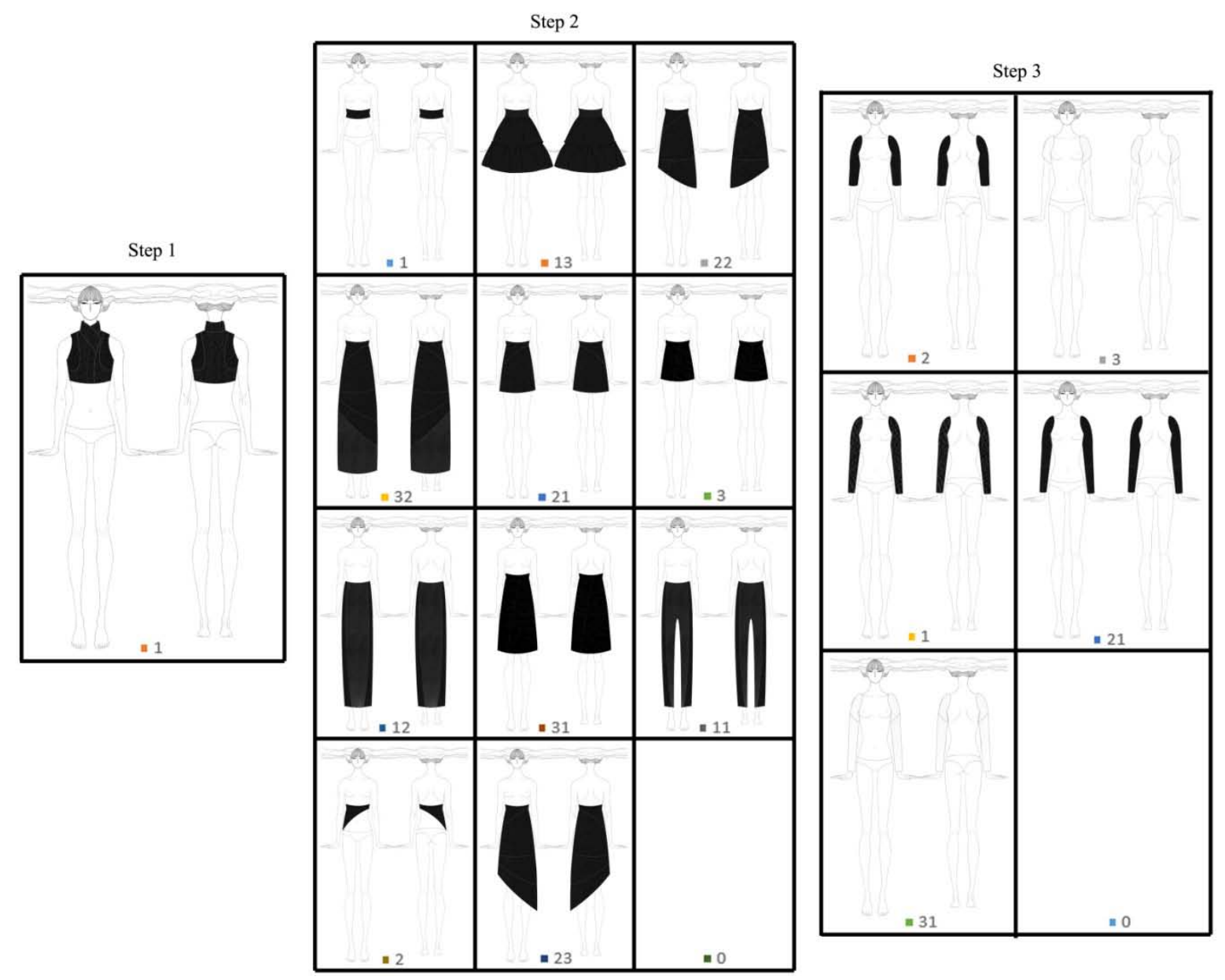

Figure 8. Co-design choices, part one 


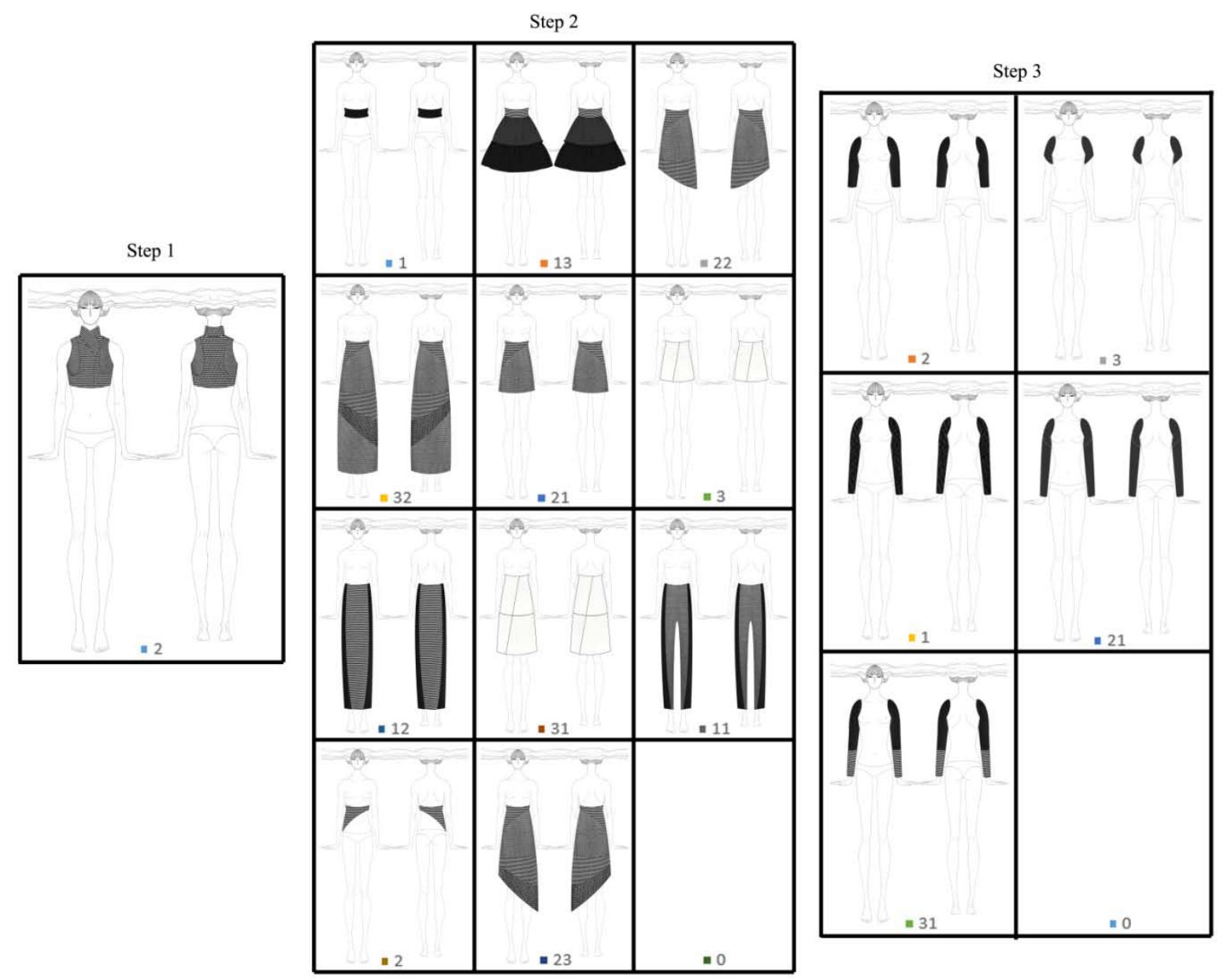

Figure 9. Co-design choices part two 

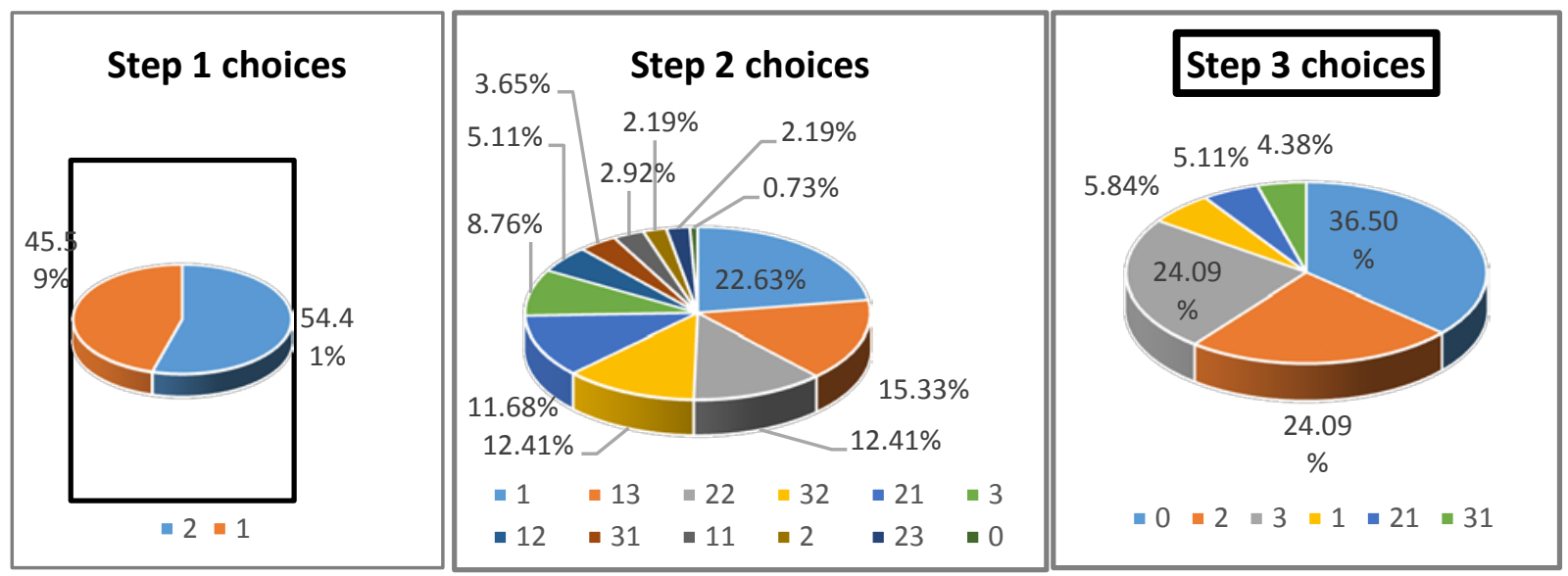

Figure 10. Results of co-design stages

Consumers rated their satisfaction with the online design experience at averages of 3.28, 2.81, and 3.15 out of five, reflecting their interest in the design method, satisfaction with their design choices, and enjoyment of the design process.

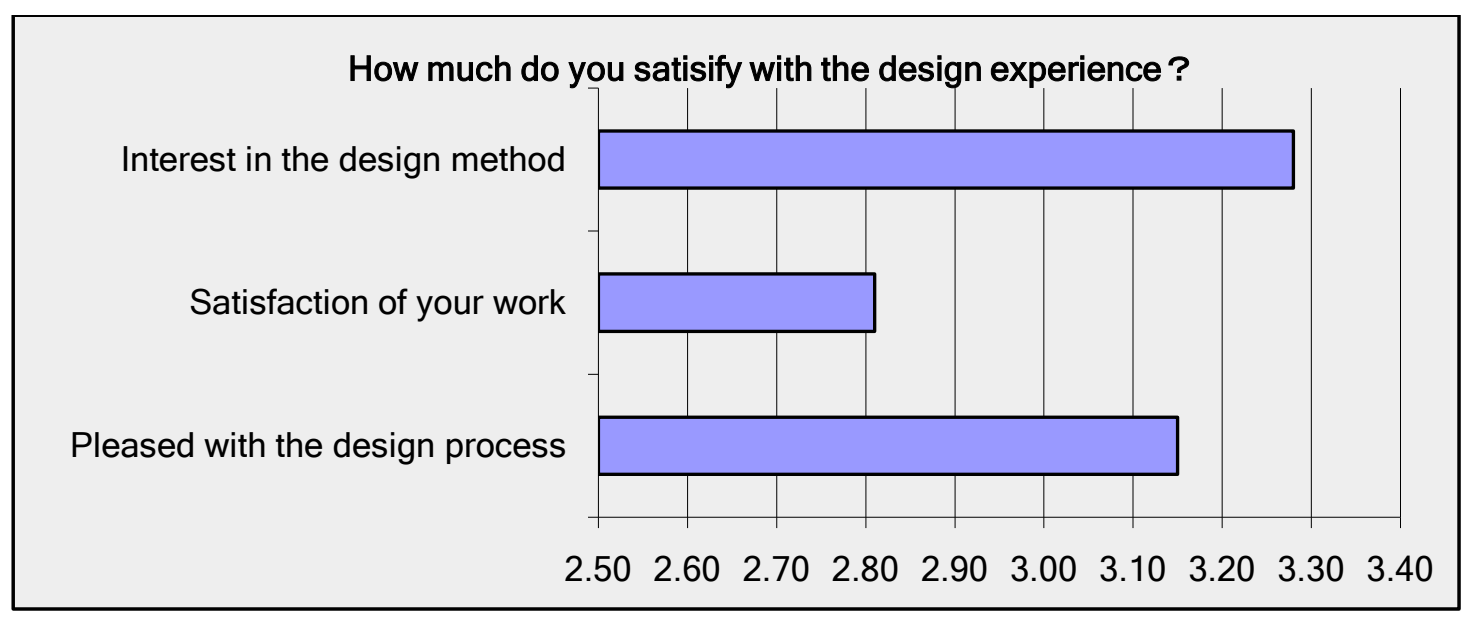

Figure 11. Satisfaction with Level of Design Experience 
5.2.3 Customized garments. As shown in Table 3, 66.7\% $(n=78)$ participants did not own personalized garments, $29.1 \%$ respondents had one to five tailored items, $3.4 \%$ participants had five to ten pieces and $0.9 \%$ purchased more than 20 articles of customized clothes. Even though most of the participants did not have customized garments, their answers to the following questions indicated that they do find them appealing. A rate of 54.7\% ( $n=64)$ of consumers suggested that they liked the idea of customized garments that had selectable features such as color, fabric, pattern and silhouette. Participants identified style, fabric, and color as the top three elements that they would like to change, should they purchase customized garments. Moreover, 42.7\% respondents enjoyed the customized design process available through the survey. Only 2.6\% participants claimed that they did not like customized garments due to the complexity of the design process.

\begin{tabular}{|l|c|c|}
\hline Have you purchased customized garments? & \multicolumn{2}{l|}{} \\
\hline Answer Options & Response Percent & Response Count \\
\hline No & $66.7 \%$ & 78 \\
\hline Yes, I have 1-5 pieces & $29.1 \%$ & 34 \\
\hline Yes, I have 5-10 pieces & $3.4 \%$ & 4 \\
\hline $\begin{array}{l}\text { I used to buy customized garments and have more than 20 } \\
\text { pieces }\end{array}$ & $0.9 \%$ & 1 \\
\hline Answered question & & 117 \\
\hline Skipped question & & 3 \\
\hline
\end{tabular}

Table 3: Purchase frequency according to customized garments 


\begin{tabular}{|l|c|c|}
\hline \multicolumn{3}{|l|}{ Regarding to customized garments, choose the options you think that are apply to you. } \\
\hline Answer Options & Response Percent & Response Count \\
\hline $\begin{array}{l}\text { I like customized garments, cause I can choose colors, } \\
\text { patterns, fabrics and styles that I like }\end{array}$ & $54.7 \%$ & 50 \\
\hline $\begin{array}{l}\text { I like customized garments, cause I enjoy the design } \\
\text { experiences }\end{array}$ & $42.7 \%$ & 3 \\
\hline $\begin{array}{l}\text { I do not like customized garments, it's too complicate for } \\
\text { me to design a garment }\end{array}$ & $2.6 \%$ & 16 \\
\hline $\begin{array}{l}\text { I do not purchase customized garments, because too few } \\
\text { shops could provide customized products. }\end{array}$ & $28.2 \%$ & 33 \\
\hline $\begin{array}{l}\text { I do not purchase customized garments, because customized } \\
\text { garments are too expensive. I would like to buy it only if } \\
\text { the price is similar to regular garments. }\end{array}$ & $12.0 \%$ \\
\hline $\begin{array}{l}\text { I do not purchase customized garments, because the process } \\
\text { of customization cost a long period of time, I prefer to } \\
\text { purchases garments directly. }\end{array}$ & $17.1 \%$ & 20 \\
\hline $\begin{array}{l}\text { I do not purchase customized garments, because there is a } \\
\text { risk about the final garments which I do not know whether } \\
\text { it is the same as I though and designed }\end{array}$ & & 117 \\
\hline Answered question & 3 \\
\hline Skipped question & & \\
\hline
\end{tabular}

Table 4: personal attitude according to customized garments

\begin{tabular}{|l|c|c|}
\hline Which are the features you want to change when you purchase customized garments? \\
\hline Answer Options & Response Percent & Response Count \\
\hline Fabric & $78.6 \%$ & 92 \\
\hline Size & $55.6 \%$ & 65 \\
\hline Color & $70.1 \%$ & 82 \\
\hline Pattern & $64.1 \%$ & 75 \\
\hline Style & $86.3 \%$ & 101 \\
\hline Collar & $47.9 \%$ & 56 \\
\hline Sleeves & $42.7 \%$ & 50 \\
\hline Length & $38.5 \%$ & 45 \\
\hline Pocket & $32.5 \%$ & 38 \\
\hline Accessories (zipper, button, lining) & $38.5 \%$ & 45 \\
\hline Answered question & & 117 \\
\hline Skipped question & & 3 \\
\hline
\end{tabular}

Table 5: Desirable options of customized features 
5.2.4 Transformable garments.Ninety-seven percent of respondents claimed that they had purchased transformable garments before, including removable hats (99/106), detachable sleeves or trouser legs 60/92), removable collars (66/95), changeable garment lengths (29/83), reversible apparel (91/100), and changeable colors (29/83). In addition, 36.5\% (42/115) stated that they liked the transformable garment features and used them frequently. 54.8\% participants indicated that they had used changeable features once or twice, and 8.7\% claimed they had not used these options. Eighty-one percent of respondents preferred one garment that offered one to three changes in style.

\begin{tabular}{|l|c|c|c|}
\hline Have you purchased below transformable garments? \\
\hline Answer Options & Yes & No & Response Count \\
\hline Detachable hats & 99 & 7 & 106 \\
\hline Removable sleeves and trousers legs & 60 & 32 & 92 \\
\hline Detachable collars & 66 & 29 & 95 \\
\hline Length of garments could be changed & 29 & 54 & 83 \\
\hline Reversible garments & 91 & 9 & 100 \\
\hline Colors could be changed & 29 & 54 & 83 \\
\hline Yes, I have transformable garments other than above choice. & & 10 \\
\hline Answered question & & 111 \\
\hline Skipped question & & 9 \\
\hline
\end{tabular}

Table 6. Purchase experiences of transformable garments

\begin{tabular}{|l|c|c|}
\hline How often did you use the transformable feature? \\
\hline Answer Options & Response percent & Response Count \\
\hline Frequently used & $36.5 \%$ & 42 \\
\hline Only once or twice & $54.8 \%$ & 63 \\
\hline Haven't used & $8.7 \%$ & 10 \\
\hline Answered question & & 115 \\
\hline Skipped question & & 5 \\
\hline
\end{tabular}

Table 7. Use frequency according to purchased transformable garments 


\begin{tabular}{|l|c|c|}
\hline How many change options you prefer when you purchase a transformable garment? \\
\hline Answer Options & Response percent & Response Count \\
\hline 0, I do not like transformable garment & $8.6 \%$ & 10 \\
\hline $1-3$ & $81.0 \%$ & 94 \\
\hline $3-10$ & $6.0 \%$ & 7 \\
\hline The more the better & $0.0 \%$ & 0 \\
\hline Answered question & & 116 \\
\hline Skipped question & & 4 \\
\hline
\end{tabular}

Table 8. Change options of transformable garments

5.2.5 Sustainable garments. The lifespan of a consumers' vest, t-shirt, top and dress is generally three months to one year, and a coat or pair of trousers may last from one to three years depending on garment construction and fabrication. The majority of participants stated that they owned one to five vests, t-shirts, tops, coats, trousers and dresses during the spring and summer seasons. Most of them spent one to ten dollars on a vest, 10 to 20 dollars on a T-shirt, and 20-50 dollars on a top, coat, pair of trousers, or dress. Sixty percent of participants (68/113) claimed that they considered sustainability when they purchased garments, but that they were not very knowledgeable about sustainable garments. Only $2.7 \%$ of respondents claimed to be very concerned about sustainability, and suggested that they understood the principles of sustainable garments very well.

\begin{tabular}{|l|c|c|}
\hline Did you pay attention on sustainability when you purchase garments? \\
\hline Answer Options & Response percent & Response Count \\
\hline No, and I'm not familiar with sustainable fashion & $37.2 \%$ & 42 \\
\hline $\begin{array}{l}\text { Yes, a little. But I'm not very understanding about } \\
\text { sustainable fashion }\end{array}$ & $56.6 \%$ & 64 \\
\hline Yes, very concern. I know some about sustainable fashion & $3.5 \%$ & 4 \\
\hline Yes, very concern. I know a lot about sustainable fashion & $2.7 \%$ & 3 \\
\hline Answered question & & 113 \\
\hline Skipped question & & 6 \\
\hline
\end{tabular}

Table 9. Attitude towards sustainability 


\begin{tabular}{|l|c|c|c|c|c|c|c|}
\hline How long is the average lifespan of your garments? \\
\hline $\begin{array}{l}\text { Answer } \\
\text { Options }\end{array}$ & $\begin{array}{c}\text { less than } 1 \\
\text { month }\end{array}$ & $\begin{array}{c}1-3 \\
\text { months }\end{array}$ & $\begin{array}{c}3 \text { months-1 } \\
\text { year }\end{array}$ & $1-3$ years & $\begin{array}{c}3-10 \\
\text { years }\end{array}$ & 10 years & Response Count \\
\hline Vest & 3 & 34 & 48 & 30 & 2 & 1 & 118 \\
\hline T-shirt & 0 & 20 & 57 & 35 & 2 & 1 & 115 \\
\hline Top & 0 & 3 & 55 & 49 & 6 & 1 & 114 \\
\hline Coat & 0 & 1 & 41 & 57 & 13 & 1 & 113 \\
\hline Trousers & 0 & 3 & 42 & 65 & 4 & 1 & 115 \\
\hline Dress & 2 & 5 & 41 & 37 & 6 & 1 & 92 \\
\hline \multicolumn{7}{l}{ Answered question } \\
\hline
\end{tabular}

Table 10. Garment lifespan

\begin{tabular}{|l|c|c|c|c|c|c|c|c|}
\hline What is the average price of your garments? \$CNY \\
\hline Answer & $10-$ & $50-$ & $100-$ & $300-$ & $500-$ & $1000-$ & $\begin{array}{c}3000 \text { and } \\
\text { bbove }\end{array}$ & Response Count \\
Options & 50 & 100 & 300 & 500 & 1000 & 3000 & 114 \\
\hline Vest & 57 & 46 & 8 & 2 & 1 & 0 & 0 & 114 \\
\hline T-shirt & 15 & 60 & 37 & 1 & 1 & 0 & 0 & 114 \\
\hline Top & 8 & 25 & 57 & 17 & 7 & 0 & 0 & 114 \\
\hline Coat & 2 & 10 & 47 & 32 & 18 & 4 & 1 & 115 \\
\hline Trousers & 2 & 22 & 67 & 20 & 4 & 0 & 0 & 92 \\
\hline Dress & 8 & 13 & 48 & 15 & 5 & 2 & 1 & 118 \\
\hline Answered question \\
\hline \multicolumn{7}{|l|}{ Skipped question } \\
\hline
\end{tabular}

Table 11. Costs of purchased garments

In regards to the three features of customization, sustainability, and transformability, 35.9\% respondents stated that they would spend 10 to $20 \%$ more for customized clothing features and less than $10 \%$ additional price for both sustainable and transformable feature. In reference to making future shopping purchases, $40.5 \%$ of participants stated that if the Chinese apparel market developed more sustainable fashions, they would be open to new designs. In addition, 46.6\% claimed that even though there were numerous products to choose from in Chinese clothing stores, they still felt it difficult to find a fashion design that they were truly happy with. 


\begin{tabular}{|l|c|c|}
\hline Choose the answers that you think are applied to current Chinese fashion market \\
\hline Answer Options & Response percent & Response Count \\
\hline Various options, I always can purchase the garments I need & $17.2 \%$ & 20 \\
\hline $\begin{array}{l}\text { Fashion trends change fast, new styles add on shelves every } \\
\text { month }\end{array}$ & $36.2 \%$ & 42 \\
\hline $\begin{array}{l}\text { Fashion market changes to diversity, consumers feel confident } \\
\text { to accept new designs }\end{array}$ & $40.5 \%$ & 47 \\
\hline $\begin{array}{l}\text { Even though there are various products, it's still hard for me to } \\
\text { find a design I want }\end{array}$ & $46.6 \%$ & 34 \\
\hline $\begin{array}{l}\text { Garments quality is not as good as previous time as fast } \\
\text { fashion becomes popular }\end{array}$ & $27.6 \%$ & 32 \\
\hline Others & & 6 \\
\hline Answered question & & 416 \\
\hline Skipped question & \\
\hline
\end{tabular}

Table 12. Opinions of Chinese fashion market

\begin{tabular}{|l|c|c|c|}
\hline \multicolumn{3}{|c|}{ Compared with regular garments, how much more you would like to spend on below designs? } \\
\hline & Customized design & Sustainable design & $\begin{array}{l}\text { Transformable } \\
\text { design }\end{array}$ \\
\hline Answer Options & Response Percent & Response Percent & Response Percent \\
\hline $0 \%$ & $1.7 \%$ & $6.9 \%$ & $11.2 \%$ \\
\hline $0 \%-10 \%$ & $12.8 \%$ & $35.3 \%$ & $30.2 \%$ \\
\hline $10 \%-25 \%$ & $35.9 \%$ & $21.6 \%$ & $27.6 \%$ \\
\hline $25 \%-50 \%$ & $22.2 \%$ & $19.8 \%$ & $12.1 \%$ \\
\hline $50 \%-100 \%$ & $21.4 \%$ & $14.7 \%$ & $17.2 \%$ \\
\hline more than 200\% & $6.0 \%$ & $1.7 \%$ & $1.7 \%$ \\
\hline answered question & $\mathbf{1 1 7}$ & $\mathbf{1 1 6}$ & $\mathbf{1 1 6}$ \\
\hline skipped question & $\mathbf{3}$ & $\mathbf{4}$ & $\mathbf{4}$ \\
\hline
\end{tabular}

Table 13. Shopping intention toward customized design, sustainable design and transformable design 


\section{Chapter 6}

\section{Conclusions}

The qualitative research that I have conducted for this study demonstrates that my transformable garment design (No. 3) can be adapted to produce different silhouettes and styles for various fashions, and may be successfully used in apparel-manufacturing processes.

Furthermore, both the interviews and online survey indicate that Chinese consumers do have an interest in transformable designs such as Garment No. 3, and may be willing to spend additional costs on three critical features of the design: customization, sustainability and transformability. The data additionally reveals that these consumers would like to participate more in the fashion design process to help produce customized, transformable and sustainable clothing that better reflects their particular needs and desires.

Both the design research and pattern making aspects of this project revealed that the design of Garment No. 3 could reflect greater sustainability in its use of fabric (e.g. leather) and accessories (e.g. metal zippers). Details such as these helped to identify sustainable fashion as a critical objective in contemporary clothing production; one that requires careful consideration of sustainability at each stage of garment design. In this project, garment design No. 3 successfully reflected sustainability in its reduction of fabric waste, extension of garment life and reduction in overall garment consumption. If, in the future, designs such as Garment No. 3 are utilized in combination with sustainable fabric sourcing and ethical labour practices, fashion design can be one step closer to achieving the goal of true sustainability. My hope is that transformable design methods will be more readily adopted by the industry and that an increasing number of designers and consumers participate in the design process, whether they are drawn in by sustainability, mass customization, or a general interest in transformable fashion. 


\section{Appendices}

\section{Appendix A: Approval from Ryerson Ethical Research Board}

\section{RYERSON UNIVERSITY \\ RESEARCH ETHICS BOARD}

To: Minjie Gong

Fashion

Re: REB 2013-292: Sustainable Fashion Design-Detachable Fashion Design with Longevity and Versatility

Date: November 5, 2013

Dear Minjie Gong,

The review of your protocol REB File REB 2013-292 is now complete. The project has been approved for a one year period. Please note that before proceeding with your project, compliance with other required University approvals/certifications, institutional requirements, or governmental authorizations may be required.

This approval may be extended after one year upon request. Please be advised that if the project is not renewed, approval will expire and no more research involving humans may take place. If this is a funded project, access to research funds may also be affected.

Please note that REB approval policies require that you adhere strictly to the protocol as last reviewed by the REB and that any modifications must be approved by the Board before they can be implemented. Adverse or unexpected events must be reported to the REB as soon as possible with an indication from the Principal Investigator as to how, in the view of the Principal Investigator, these events affect the continuation of the protocol.

Finally, if research subjects are in the care of a health facility, at a school, or other institution or community organization, it is the responsibility of the Principal Investigator to ensure that the ethical guidelines and approvals of those facilities or institutions are obtained and filed with the REB prior to the initiation of any research.

Please quote your REB file number (REB 2013-292) on future correspondence.

Congratulations and best of luck in conducting your research.

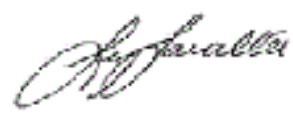

Lynn Lavallée, $\mathrm{Ph} . \mathrm{D}$.

Chair, Research Ethics Board 


\section{Appendix B: Interview Consent Form}

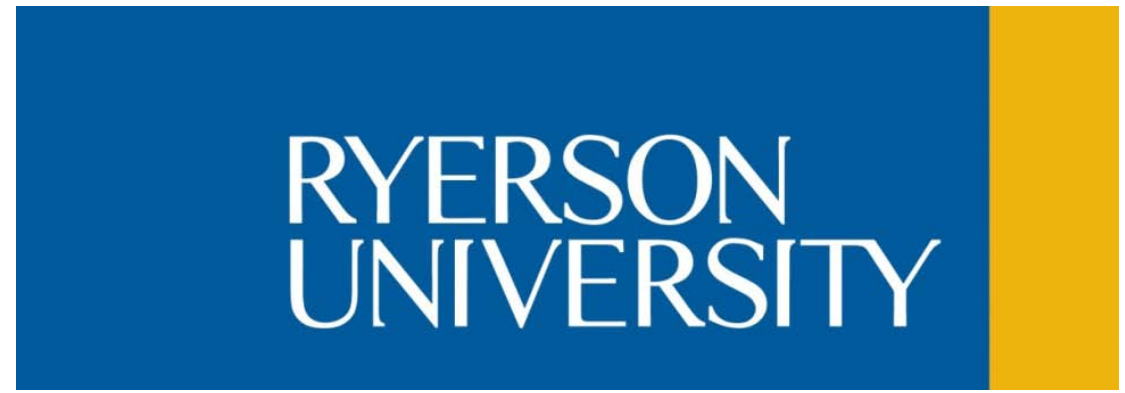

加拿大多伦多瑞尔森大学时装学院

文学硕士学位毕业论文

研究参与授权同意书

\section{研究 $\square$ 目名称 :}

可持 $\square \square$ 装 $\square \square$ —永久且多功能可拆卸式服装 $\square \square$

$\square$ 迎您参与 $\square \square$ 研究 $\square$ 目。在您参与前 $\square$ 仔 $\square \square \square$ 此同意 $\square$ 以便于您了解参与研究的内容, 您可以向研究者 $\square \square$ 任何 $\square \square$ 以便您了解 $\square \square$ 研究。

\section{研究者 :}

主研究者：

Minjie Gong ( $\square$ 敏 $\square$ ) 瑞 $\square$ 森大学 $\square$ 装学院文学 $\square$ 士在 $\square$ 研究生

第一指 $\square$ 教授 :

Osmud Rahman 瑞 $\square$ 森大学 $\square$ 装学院教授

第二指 $\square$ 教授 : 
Susan Barnwell 瑞 $\square$ 森大学 $\square$ 装学院教授

\section{研究目的 :}

此研究 $\square$ 目是通 $\square$ 研究可拆卸式 $\square$ 装 $\square \square$ 的概念来提高服装的可持 $\square \square$ 展性。在 $\square$ 有的研 究成果中，已有各种各 $\square$ 的 $\square \square$ 概念可以 $\square \square \square$ 可持 $\square \square$ 装 $\square \square$ ，其中包括零面料浪 $\square \square$ $\square$, 高科技融入 $\square \square$ 以及可 $\square \square \square \square$ 。 $\square$ 个研究 $\square$ 目将 $\square$ 新一种可拆卸式 $\square \square$ 的概念来达 到服装的可持 $\square$ 性运用。通 $\square$ 拆卸或者替 $\square$ 服装的不同部位来达到一件服装可以衍 $\square$ 成多 种款式和无限延 $\square$ 一件服装的寿命的目的。可拆卸式 $\square$ 装 $\square \square$ 是一个新的 $\square \square \square$ 新，它能 从宏 $\square$ 上减少面料的浪 $\square$, 提高一件服装的使用 $\square$ 效, $\square$ 展一件服装的功能性, 并鼓舞消 $\square$ 者参与到可持 $\square$ 性 $\square \square$ 中。 $\square$ 次 $\square \square$ 中收集到的数据将会被用于 $\square$ 述和分析可拆卸式 $\square$ 装 $\square \square$ 的商 $\square$ 潜力，可持 $\square$ 性的效果以及 $\square \square$ 美方面的考 $\square$ 。

\section{研究方式:}

一 $\square \square \square$ : 将 $\square \square$ 七位 $\square$ 装 $\square$ 深人士，包括两位 $\square$ 装 $\square \square \square$ ，两位 $\square$ 装学者以及三位服 装企 $\square$ 家。将通 $\square \square \square$ 他 $\square$ 一系列 $\square \square$ 来研究可拆卸式 $\square$ 装 $\square \square$ 的可持 $\square$ 性, 美 $\square$ 性, 功 能性以及商 $\square$ 潜力。相关 $\square$ 片以及可拆卸式服装将会在 $\square \square \square$ 程中展示几分 $\square \square \square$ 。 $\square \square$ 将以 $\square$ 音方式 $\square$ 行, $\square \square$ 大 $\square$ 四十五至六十分 $\square$ 。

\section{$\square \square \square$ 估:}

此研究 $\square$ 目并没有已知或可 $\square \square$ 到的 $\square \square$ 。采 $\square \square$ 程中提出的 $\square \square$ 将不会涉及到私人及敏 感 $\square \square$ 。然而在采 $\square \square$ 程中, 如参与者在 $\square \square$ 中出 $\square$ 任何不适, 参与者可以 $\square \square$ 性或者永 久性的 $\square$ 止 $\square \square$ 。参与者将不会从此研究 $\square$ 目中 $\square$ 得直接利益。

\section{利益 $\square$ 估：}

参与者不会从 $\square \square$ 研究中 $\square$ 得直接利益, 但是参与者的参与将促 $\square$ 服装界中可持 $\square$ 性 $\square$ 品 的研 $\square$ 。

\section{参与者 $\square$ 私保 $\square$ :}

所有研究数据将被保存于安全的硬 $\square$ 中, 并需要密 $\square$ 登 $\square$ 。只有主研究者及其第一指 $\square$ 教 授有 $\square$ 格 $\square$ 入以及 $\square \square$ 。在适当 $\square$ 期被 $\square \square$ 者将有机会了解研究 $\square$ 体 $\square$ 果。在 $\square \square$ 内容以 任何形式 $\square$ 表前, 被 $\square \square$ 者可以 $\square \square$ 和修改 $\square \square$ 内容。所有数据将被保存三年后被清除。 
研究 $\square$ 果将被用于研究者的 $\square \pm \square \square \square$ 文, 并可能在关于 $\square$ 装可持 $\square$ 性 $\square \square$ 的相关会 $\square$ 及 刊物中 $\square$ 表。

\section{参与者 $\square$ 益及自愿参与:}

参与 $\square \square$ 研究，参与者将不会被支付 $\square$ 酬。参与 $\square \square$ 研究是参与者的自愿行 $\square$ 。如果您 $\square$ $\square$ 参与, 您也可以在任何 $\square \square$ 退出或 $\square$ 止参与此研究。退出或 $\square$ 止此研究 $\square$ 您将不会有任 何 $\square$ 益的 $\square$ 失。在研究的任何 $\square$ 段您都可以拒 $\square$ 回答任何一个 $\square \square$ 或者 $\square$ 止参与。

\section{$\square$ 此研究有疑 $\square$ :}

如果您 $\square$ 此研究 $\square$ 目有任何的 $\square \square, \square \square$ 系：

主研究者：Minjie Gong（ $\square$ 敏 $\square ） ，$ 加拿大多 $\square$ 多市瑞 $\square$ 森大学 $\square$ 装学院研究生部

$\square$ 子件 : minjie.gong@ryerson.ca

第一指 $\square$ 教授: Osmud Rahman 瑞 $\square$ 森大学 $\square$ 装学院教授

$\square$ 子 $\square$ 件 : orahman@ryerson.ca $\square \square:$ 416-979-5000 x.6911

如果您 $\square$ 您的个人 $\square$ 益及参与有任何疑 $\square, \square \square$ 系加拿大多 $\square$ 多市瑞 $\square$ 森大学研究 $\square$ 理委 $\square$ 会 $\square$ 行咨 $\square$ 。

地址 : 加拿大, 安大略省, 多 $\square$ 多市, $\square$ 多利 $\square$ 路350号, 瑞 $\square$ 森大学, $\square$ 理咨 $\square$ 委 $\square$ 会, 研究及 $\square$ 新副 $\square$ 裁 $\square$ 公室

$\square \square:$ M5B2K3

: 416-979-5042

引用允 $\square:$

研究者可能会在 $\square$ 文或者 $\square$ 表刊物中引用您在 $\square \square$ 中的 $\square$ 点。关于引用的方式， $\square$ 在以下 的 $\square$ 述中 $\square \square$ 是或否 : 


\begin{tabular}{|c|c|}
\hline $\begin{array}{l}\text { 我同意研突 } \\
\square \text { 授予研究 }\end{array}$ & $\begin{array}{l}\text { 下情况下引用我的言 } \square \text { 于 } \square \text { 文 } \square \text { 表中（点 } \square \text { 以下任一 } \square \\
\text { 文 } \square \text { 表版 } \square \square \text { 可）： }\end{array}$ \\
\hline$\square$ 是口否 & 我同意我的 $\square$ 点被直接引用 (姓名被引用) \\
\hline$\square$ 是 $\square$ 否 & 我同意在不用我姓名的情况下我的 $\square$ 点被引用(匿名引用). \\
\hline$\square$ 是 $\square$ 否 & 我同意在用假名的情况下我的 $\square$ 点被引用（假名引用） \\
\hline
\end{tabular}

\section{同意声明：}

以下您的 $\square$ 名表明您已 $\square \square \square$ 了本 $\square \square$ 中的信息并已有机会提出相关疑 $\square$ 。若无任何异 $\square$, $\square \square$ 署本同意 $\square$ 并参与此研究。以下 $\square$ 名也表明您已 $\square$ 被告知您有 $\square$ 利在任何情况下退出 本研究。您将被 $\square$ 予此同意 $\square$ 的副本。

您已被告知 $\square$ 署此同意 $\square$ 的同 $\square$ 您并没有放弃任何您的合法 $\square$ 益。

参与者姓名（由正楷填写）

参与者 $\square$ 名

日期 
研究者 $\square$ 名

日期 


\section{Appendix C: Interview Questions}

$\square$ 象 : 企 $\square$ 家

1. 你什么时候创办的你的公司?

2. 你从事服装多久了?

3. 你的公司销售哪些类型的服装（男装, 女装, 春秋, 冬夏) ?

4. 你们销售的服装款式有什么? 哪种顾客最喜欢, 衣长, 袖长分别是什么?

5. 你们销售的服装颜色有什么? 哪种顾客最喜欢

6. 你们销售的服装面料有什么? 哪种顾客最喜欢

7. 在你销售的服装里, 还有什么品牌特征吸引顾客?

8. 你感觉你从事服装以来, 服装里最大的变化是什么?

9. 你有感受到服装近年来的多样化设计吗? 你对多样化的设计有什么看法? 你愿意接受一些 新的设计方法吗?

10. 你怎么看待功能性服装?

11. 你所销售服装里有可以拆卸的服装类型吗?

12. 你销售的服装里有没有非常相似的款式，仅仅是细节在变化，比如说一样的衣服不同的领 子, 一样的外形不同的面料等

13. 如果服装的领子, 衣长可以变换, 你觉得你会生产吗?

14. 对服装的定价, 你觉得相对于不能变换的服装, 可拆卸可变化服装的做工和售价你觉得会 有什么变化?

15. 哪些类型的服装你认为适合可拆卸服装?

16. 在可拆卸服装里, 颜色, 图案, 款式, 领子造型, 袖子款式, 衣长, 那种是最适合变换的? 为什么?

17. 如果衣服可以变化, 有多少种变换方式你认为比较适合? 还是说越多越好?

18. 你认为这件设计在中国有市场吗?

19. 你怎么看这件设计

20. 你认为它的优势在哪

21. 你觉得哪些地方需要改进?

22. 这种设计方法你认为在生产和销售上面可行吗?

23. 从外观上, 你觉得怎么样?

24. 从功能上, 你觉得它怎么样, 能满足消费者的需求吗?

25. 你认为一件衣服功能性和美观的重要性应该怎么分配, 怎么平衡?

26. 你怎么理解环保时装?

27. 你认为它是一件环保服饰吗?

28. 你对这些连接拉链有什么看法? 其他还有哪些连接可以代替吗?

$\square$ 有什么是我没有提及，你愿意 $\square$ 充的 $\square$ ? 


\section{Appendix D: Online Survey Questions}

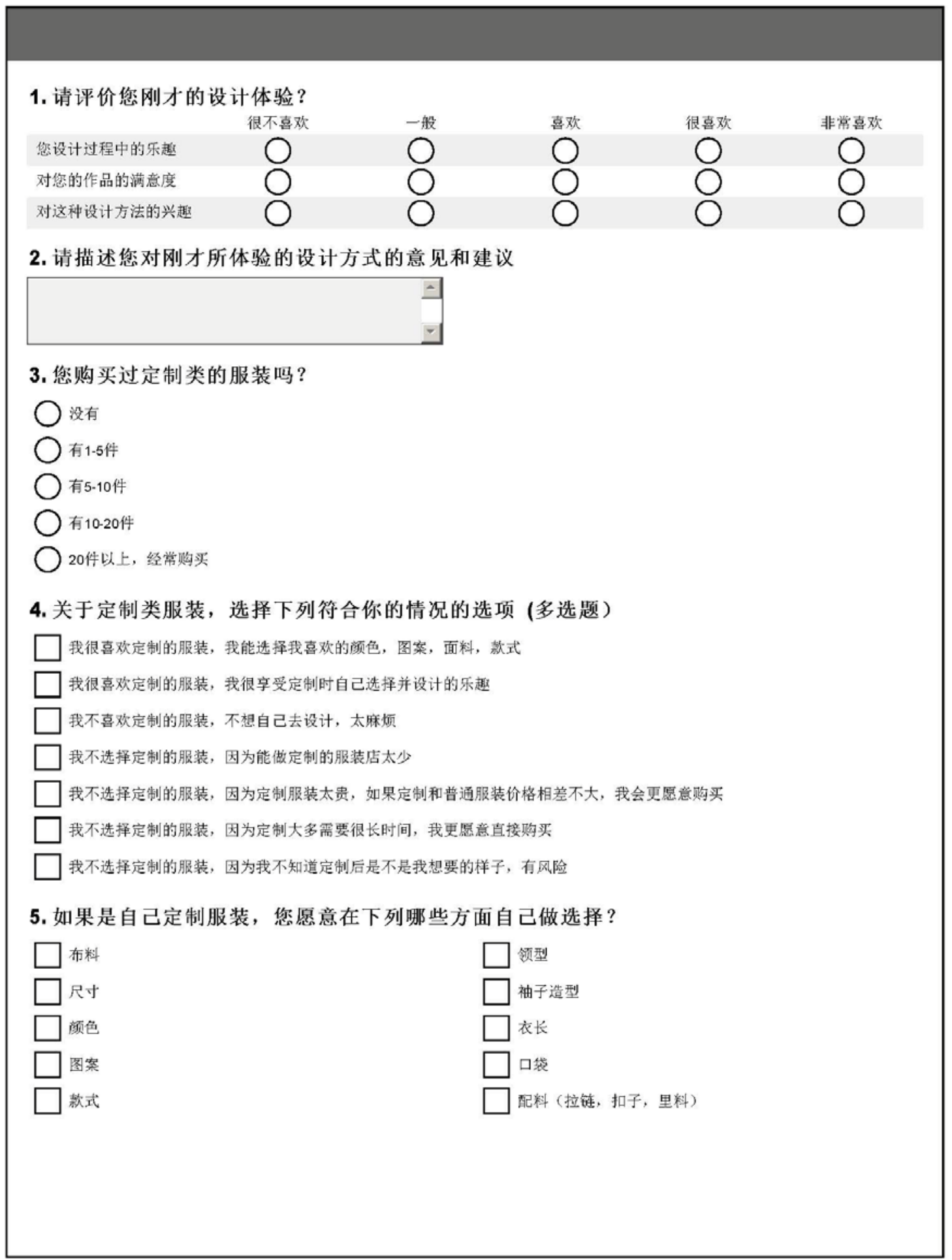




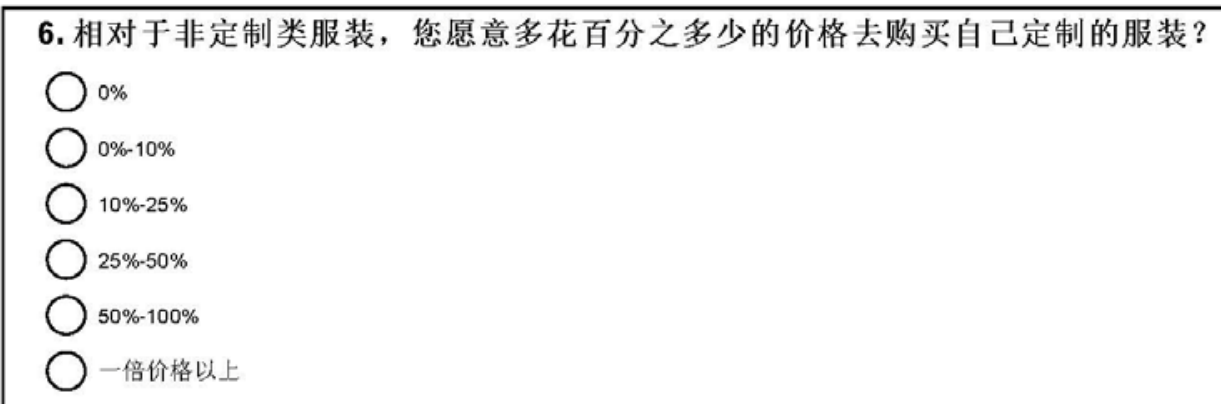

7. 您有购买过下列可变化服装吗?

峘子可拆卸
袖子或浑腿可拆卸
衣领可拆卸
衣长可变化

如有其他类型变化, 请描述

8. 如有购买过上述服装, 您有使用它可变化的功能吗?
有, 我很喜欢变化的功能, 经常使用
有, 只使用过一两次, 不方便
完全没有使用

9. 如果一件服装的款式可以变换, 多少种变换方式你会喜欢?
○, 我不喜欢变换的衣服
1-3种
3-10种
10-20种
越多越好

10. 相对于不可变化的服装, 您愿意多花百分之多少的价格去购买可变化服装?

○, 不愿多花钱在附加功能上

\% $10 \%$ 以下

10\% $25 \%$

25\%.50\%

50\% $100 \%$

一倍价格以上 


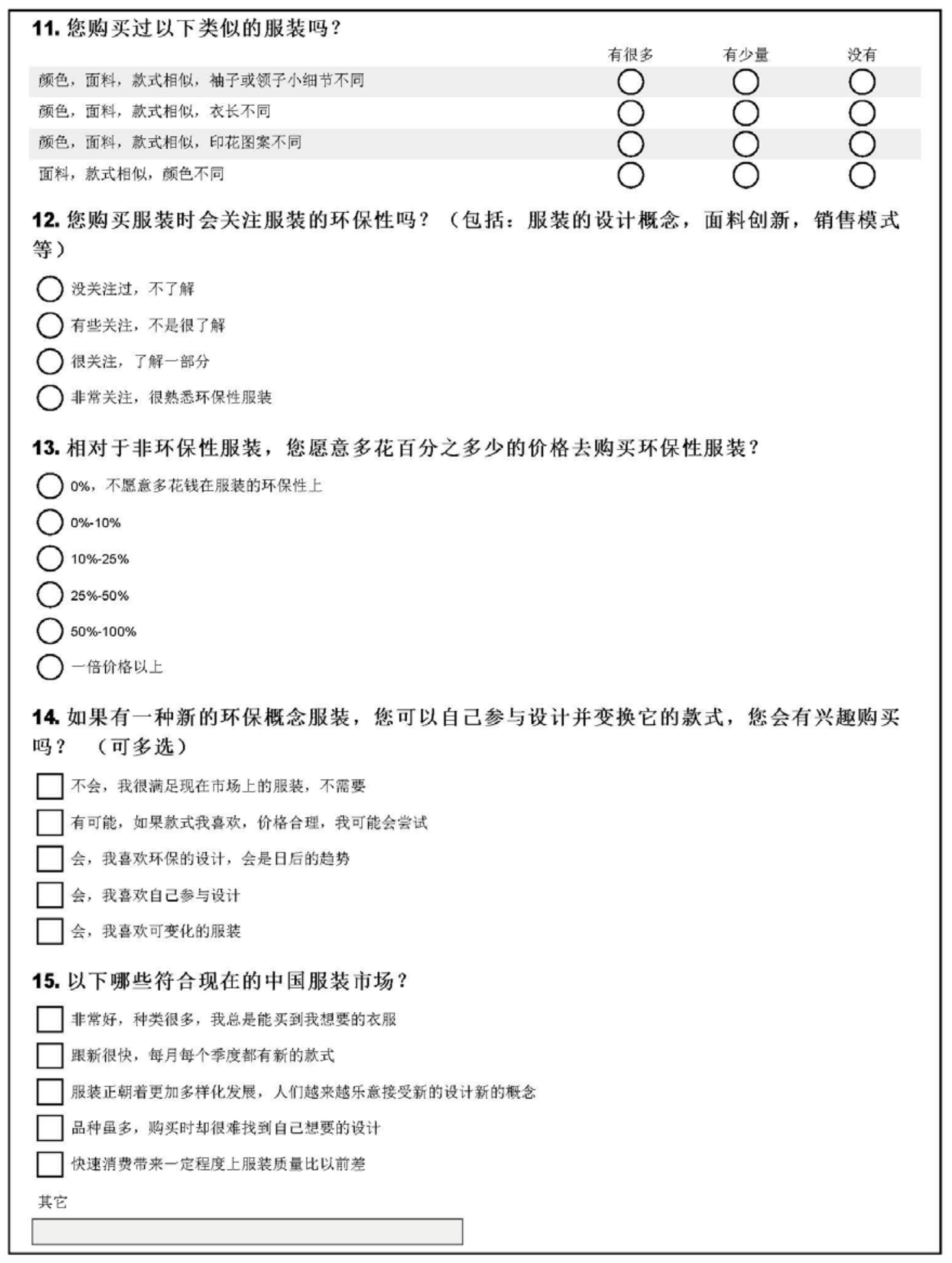


16. 春夏季节您平均每月在服装上的消费约为多少人民币?

$\square$ 100以下
$\square$ 100-300元
$\square$ 300-600元
$\square$ 700-1500元

$\square$ 1500-3000元
$\square 3000-5000$ 元
$\square 5000-1,0000$ 元
$\square$ 1,0000以上

17. 春夏季节您平均有多少件下类服装?

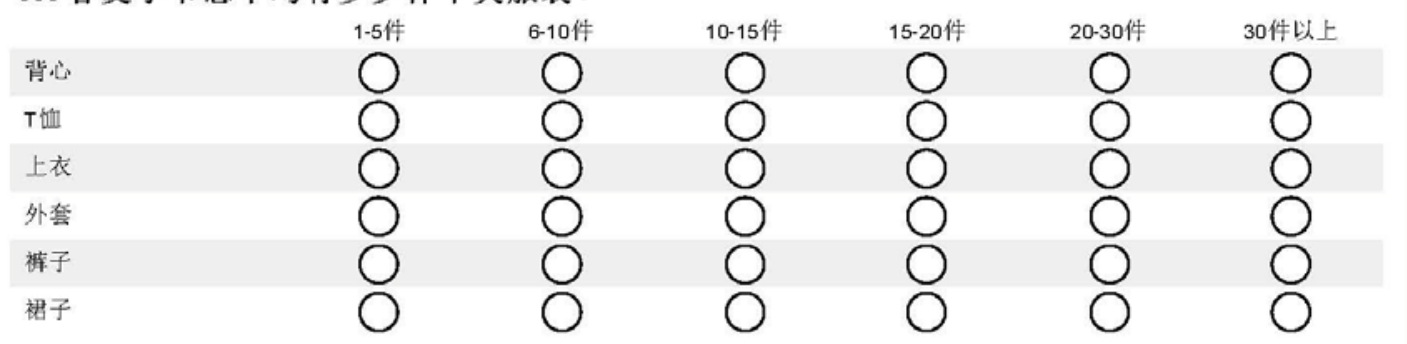

18. 你常购买的衣服价格范围是多少人民币（元）?

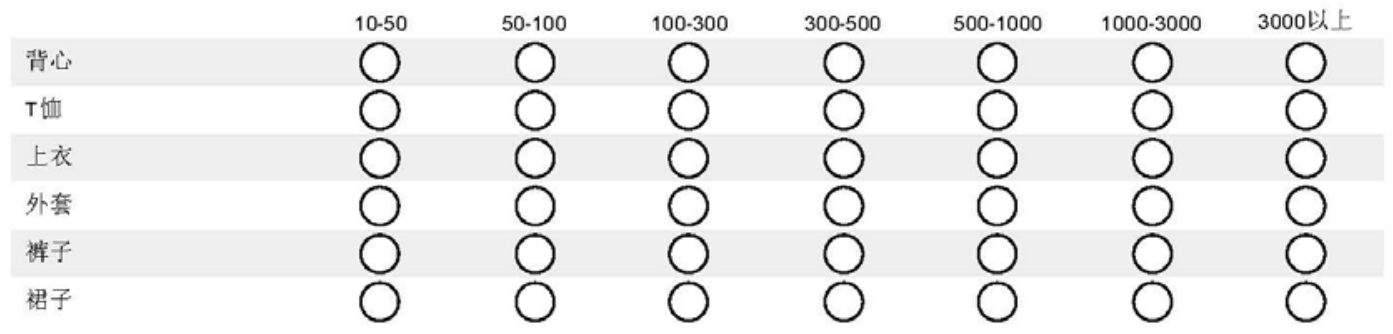

19. 您购买的以下服装穿着寿命平均是多久?

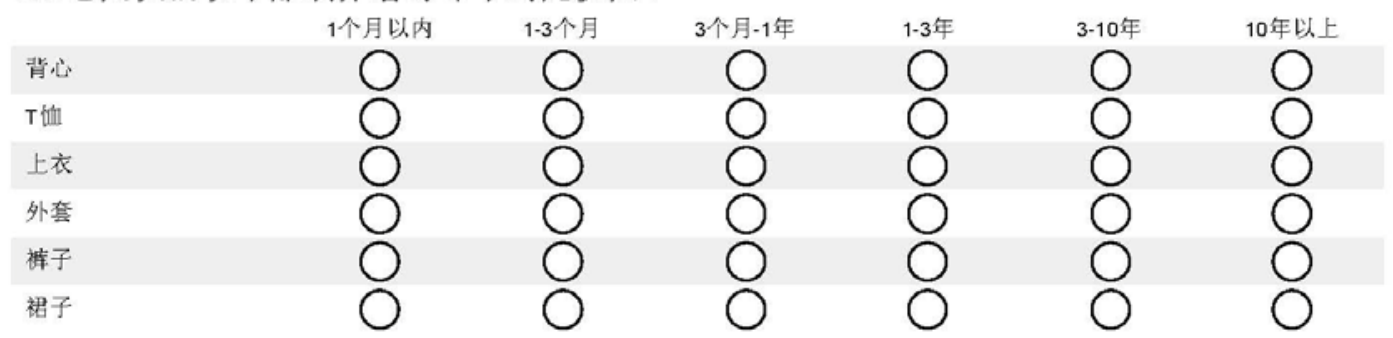

20. 您的月收入属于以下哪个范围?
○1500以下
5000-10,000
1500-3000
10,000-50,000
3000-5000
50,000以上 


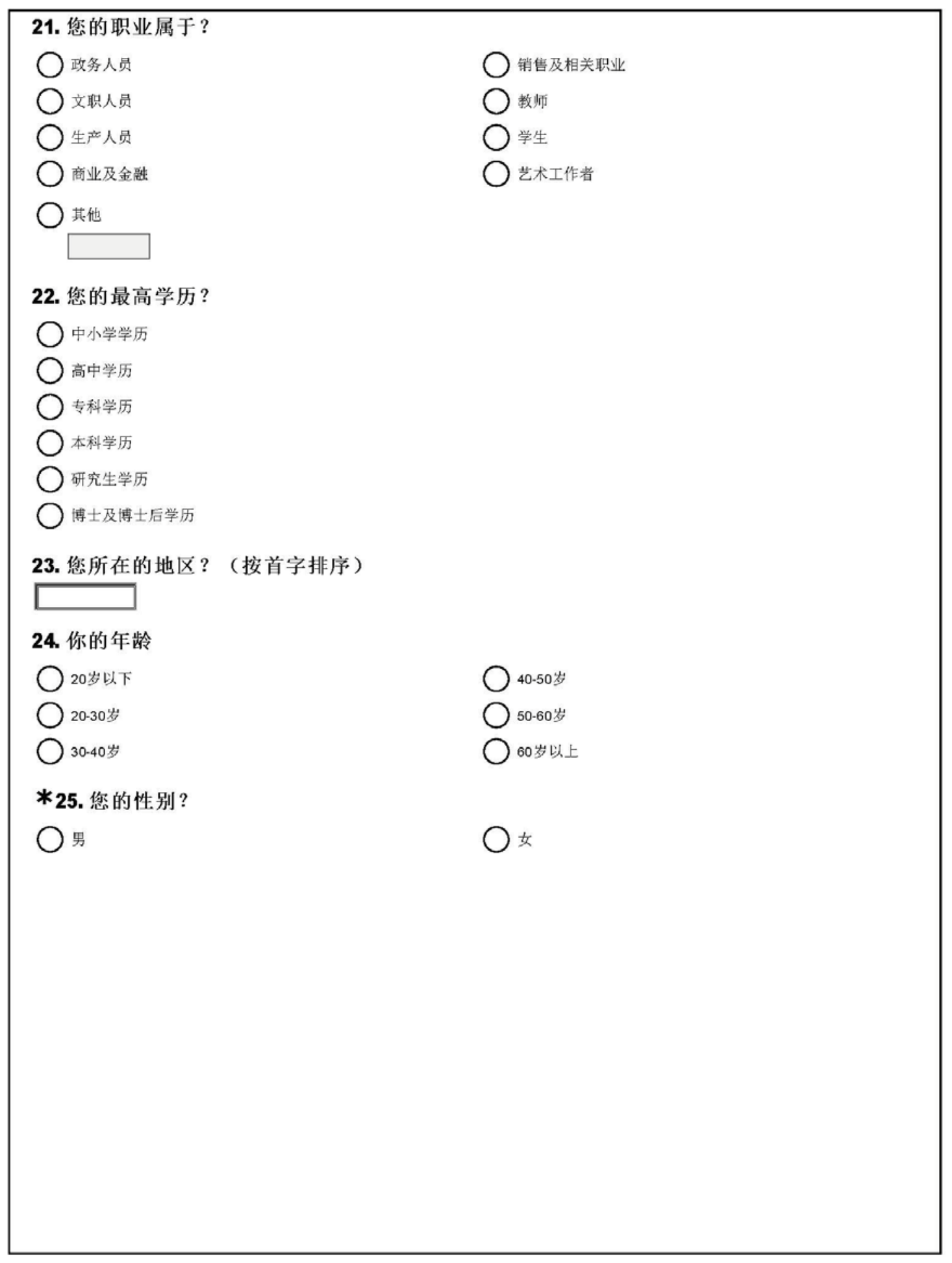




\section{Referneces}

Allwood, J. M., Laursen, S. E., de Rodriguez, C. M., \& Bocken, N. (2006). Well dressed? The present and future sustainability of clothing and textiles in the United Kingdom. PUBLISHING PLACE: University of Cambridge Institute for Manufacturing.

Anderson, D. M., \& Pine II, J. B. (1997). Agile product development for mass customization: How to develop and deliver products for mass customization, niche markets, JIT, build-toorder, and flexible manufacturing.Burr Ridge, IL: Irwin Professional Pub.

Anderson, L. J., Brannon, E. L., Ulrich, P. V., Marshall, T., Staples, N., Grasso, M.,\& Beninati, M (1997).Discovering the process of mass customization: A paradigm shift for competitive manufacturing. (National Textile Center Annual Report, August 1995).

Banim, M., \& Guy, A. (2001). Discontinued selves: Why do women keep clothes they no longer wear? In A. Guy, E. Green, \& M. Banim (Eds.), 'Through the Wardrobe’: women’s relationships with their clothes (pp. 203-219). Oxford, UK: Berg.

Berman, B. (2002). Should your firm adopt a mass customization strategy? Business Horizons, 45(4), 51-60.

Black, S. (2008). Eco-chic the fashion paradox. London: Black Dog Pub.

Brundtland Commission. (1987). Our common future (ch. 2, para I). Retrieved from http://www.un-documents.net/ocf-02.htm

Bye, E. (2010). Fashion design. Oxford, UK: Berg

Davis, S. M. (1987).Future perfect. New York: Addison-Wesley

Dombek-Keith, K., \&Loker, S. (2011). Sustainable clothing care by design. Shaping Sustainable Fashion: Changing the way we make and use clothes, 101-18. 
Duray, R., Ward, P. T., Milligan, G. W., \& Berry, W. L. (2000). Approaches to mass customization: Configurations and empirical validation.Journal of Operations Management, 18(6), 605-625.

Farrer, J. (2011). Remediation: discussing fashion textiles sustainability. InA. Gwilt \& T. Rissanen (Eds.), Shaping sustainable fashion: Changing the way we make and use clothes (pp.19-34). London, UK: Earthscan,.

Feitzinger, E., \& Lee, H. L. (1997).Mass customization at Hewlett-Packard: The power of postponement. Harvard Business Review, 75(1), 116-121.

Fiore, A., Lee, S., \& Kunz, G. (2004).Individual differences, motivations, and willingness to use a mass customization option for fashion products.European Journal of Marketing, 38(7), $835-849$.

Fiore, A. M., Lee, S. E., Kunz, G., \& Campbell, J. R. (2001). Relationships between optimum stimulation level and willingness to use mass customisation options. Journal of Fashion Marketing and Management, 5(2), 99-107.

Fletcher, K. (2008). Sustainable fashion and textiles: Design journeys. London, UK: Earthscan.

Fralix, M. T. (2001). From mass production to mass customization. Journal of Textile and Apparel, Technology and Management, 1(2), 1-7.

Gwilt, A., \& Rissanen, T. (Eds.). (2011). Shaping sustainable fashion: Changing the way we make and use clothes. London, UK: Earthscan . 
Harper, D. (2002)), 'Talking about pictures: A case for photo elicitation', Visual Studies, 17:1, pp. 13-16.

Hawley, J. (2008). Economic impact of textile and clothing recycling. In J. Hawley Hethorn \& C. Ulasewicz (Eds.) Sustainable Fashion: Why now?: A conversation about issues, practices, and possibilities (pp. 207-232). New York, NY: Fairchild Books.

Huang, C. C. (2011). On the Designing and Prototyping of Kinetic Object: Examples of "MSOrgm" and "Smart Tiles" (Unpublished doctoral dissertation). National Taiwan University of Science and Technology, Taipei, Taiwan.

Lee, J., Cho, H. S., Lee, Y. J., \& Cho, H. K. (2010). 2 Designing Technology for Smart Clothing. Smart Clothing, 37 .

Lee, S. E., Kunz, G. I., Fiore, A. M., \& Campbell, J. R. (2002).Acceptance of mass customization of apparel: merchandising issues associated with preference for product, process, and place. Clothing and Textiles Research Journal, 20(3), 138-146.

Lego.com (2014). About us: The LEGO group. Retrieved from http://aboutus.lego.com/enus/lego-group/the_lego_history.

Lewis, V. D. (2008). Developing strategies for a typology of sustainable fashion design. In J. Hawley Hethorn \& C. Ulasewicz (Eds.) Sustainable Fashion: Why now?: A conversation about issues, practices, and possibilities (pp. 233-268). New York, NY: Fairchild Books.

Loker, S. (2008). A technology-enabled sustainable fashion system: Fashion's future. In J. Hawley Hethorn \& C. Ulasewicz (Eds.) Sustainable Fashion: Why now?: A conversation about Issues, practices, and possibilities (pp. 95-126). New York, NY: Fairchild Books. 
Lott, C. (2001). Mass Customisation: The impact of mass customisation-technologies on the clothing industry-focusing on the UK and Germany (Doctoral dissertation).Retrieved from Diplomarbeiten Agentur.

Luke, R. (2008). Popular culture, marketing, and the ethical consumer. In J. Hawley Hethorn \& C. Ulasewicz (Eds.) Sustainable Fashion: Why now?: A conversation about Issues, practices, and possibilities (pp. 77-94). New York, NY: Fairchild Books.

McQuillan, H. (2011). Zero- waste design practice: Strategies and risk taking for garment design. InA. Gwilt \& T. Rissanen (Eds.), Shaping sustainable fashion: Changing the way we make and use clothes (pp. 83-100). London, UK: Earthscan.

Miyake, I., Fujiwara, D., Kries, M., \& Vitra Design Museum. (2001). A-Poc making: Issey Miyake \& Dai Fujiwara. Weil Am Rein: Vitra Design Museum.

Pine, B. J. (1993). Mass customization: the new frontier in business competition. Boston, Mass.: Harvard Business School Press.

Rissanen, T. (2008). Creating fashion without the creation of fabric waste. In J. Hawley Hethorn \& C. Ulasewicz (Eds.) Sustainable Fashion: Why now?: A conversation about Issues, practices, and possibilities (pp. 184-206). New York, NY: Fairchild Books.

Sawhney, M. S. (1998). Leveraged high-variety strategies: From portfolio thinking to platform thinking. Journal of the Academy of Marketing Science, 26(1), 54-61.

Senanayake, M. M. (2004). Mixed mass production and mass customization: Best practices for apparel. (Order No. 3128790, North Carolina State University). ProQuest Dissertations 
and Theses,, 368-368 p. Retrieved from

http://ezproxy.lib.ryerson.ca/login?url=http://search.proquest.com/docview/305166400?acc ountid=13631. (305166400).

Thorpe, A. (2006). The designer's atlas of sustainability. Washington, D.C. : Island Press.

Tokatli, N. (2008) Global sourcing insights from the clothing industry: The case of Zara, a fast fashion retailer.Journal of Economic Geography 8: 21-38.

Vartan, S. (2008). The Eco Chick guide to life: How to be fabulously green. New York, NY: St. Martin's Griffin.

Woodward, S. (2007). Why women wear what they wear. New York, NY: Berg. 